

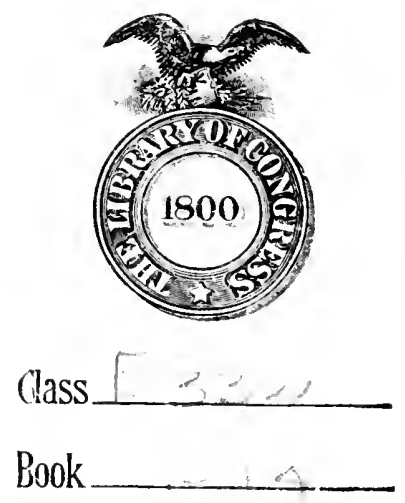








\title{
Autobiography of
}

\section{Thomas Jefferson}

\author{
I 743-I 790
}

Together with

A Summary of the Chief Events in Jefferson's Life

An Introduction and Notes by

Paul Leicester Ford

and

A Foreword by

George Haven Putnam

G. P. PUTNAM'S SONS NEW YORK AND LONDON Tbe Tknicketbocker Ipresg I9I 4 
! 


\section{CONTENTS}

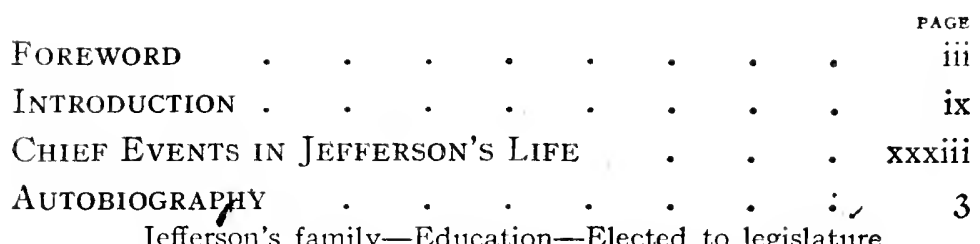

Jefferson's family-Education-Elected to legislature -Marriage-Political risputes with England-Origin of Committees of Correspondence-Rallying the peoplePrepares Summary View-Elected to Congress-Drafts a Declaration on taking up arms-Congressional debates on Declaration of Independence-Text of the Declaration of Independence-Congressional debates on Confederation-Leaves Congress and attends Virginia legislature -Drafts.bills-Aids in preparing a proposed codeElected Governor-Elected to Congress-Plans money unit-Proposes Committee of Congress-Proceedings on English treaty-Appointed to negotiate European treaties-Sails for France-Prepares Notes on VirginiaNegotiates with European states-Proposes united action against Barbary states-Beginning of the French revolution-The federal constitution-Dangers from the judiciary-Bankruptcy of the union-Progress of the French revolution-Meeting of "Patriots" at Jefferson's house-Jefferson sails for America-Accepts position of Secretary of State-Calls on Franklin-Conduct of W. T. Franklin-Jefierson arrives at New York. 



\section{FOREWORD}

The Autobiography left by 'Thomas Jefferson belongs to the literature of the Nation. The important part played by the great Virginian in the organization of the Republic and in the leadership of affairs during the first three or four Administrations, the distinctive character of the man, his imagination, his intellectual force, and his patriotism, have served to make Thomas Jefferson a great figure in American history. Even his fiercest opponents in his own generation and of later years, those who believed that his theories would prove detrimental to the interests of the State, have been ready to admit that he had honestly at heart the welfare of his fellowcitizens and of mankind, and to admit further that he must take rank among the great Americans.

The peculiar value that is possessed by a narrative in autobiographical form does not rest on the probability that the statement of facts or the record of facts and the motives which influence action would be presented more accurately than in a narrative by another hand. It may easily be the case that the memory of a writer as to the events of his earlier life will not prove as trustworthy as records left by his contemporaries. The writer of an autobiography 
will not only be confused in his memories, but these memories may themselves be affected by vanity, or by the natural human desire to put the best appearance upon one'sindividual actions and utterances, and to estimate at its full value any service that has been rendered to the community. Autobiographies must, of course, differ very materially in their trustworthiness, according to the character and the temperament of their several writers. No biographical record can, however, preserve the distinctive personality of a man in the way in which such personality is revealed in a diary or autobiographical subject. A man's character and nature are indicated as well by the matters in which he is reticent as by those concerning which he claims or believes himself to be making a full and candid presentation of the action and of the motive for the action.

An autobiographical sketch written in later life presents evidence also of changes in point of view, of the development of character, and of the acceptance of later beliefs, convictions, and ideals. The descriptions given by an old man of his own actions in youth, even when not accompanied by any express criticism or detailed analysis, possess interest and value as pictures of the double personality - that of youth and that of maturity.

It is very much to be regretted that the narrative of Jefferson, the writing of which was begun in $182 \mathrm{I}$, in his seventy-seventh year, is brought down only to the 29 th of July, I790. His life extended from I 743 to $\mathrm{r} 826$, a period which included the development of the colonies, the strenuous years of the War of the 


\section{Foreword}

Revolution, and the critical period of the organization and re-organization of the State. Jefferson's opinions of the events of the second Administration of Washington and of the Administration of Adams would have had a special interest. His own two Administrations covered the years $\mathbf{1} 80 \mathrm{I}-\mathbf{1} 809$, but his opinions as to the management of affairs by his successor, James Madison, who had the mortification of being driven out of the Capitol by the British invader, and of the work done by James Monroe would have possessed historic value and personal interest.

There is much, however, both of value and of interest in the pages that were put into shape and that have fortunately been preserved. After presenting the data concerning the Jefferson family, the narrative proceeds with a record of the events preceding the Revolution,--events in which Jefferson's leadership was important. One of the first general statements made in behalf of the contentions of the colonists, was written in 1774 by Jefferson under the title of "A Summary View of the Rights of British America." The author tells us that the pamphlet found its way to England, and, with some additions, was utilized by Mr. Burke and his associates and ran through several editions.

Jefferson claims that the credit for initiating the committees of correspondence belongs not to Massachusetts but to Virginia. The first of such committee work was done under his direction in Virginia, as far back as 1773. The account of the placing in the hands of Jefferson the task of preparing the famous 
Declaration of Independence is given in full, and is probably the chief authority on the matter.

In the later constitutional discussions, Jefferson placed himself with the group which contended that representation in Congress should be based upon population or on voters. He saw no reason why Io,ooo people should, by calling themselves a state, secure as large a representative power in the Government as belonged to 50,000 people. The jealousy and apprehensions of the smaller states, such as Rhode Island and Delaware, that the Government might be entirely controlled by states like Pennsylvania, Virginia, and New York proved, as we know, sufficient to secure an equal state representation in the Upper House of Congress. It was supposed that the evil of this disproportioned representation would at least be restricted to the original group of states; but in comparatively recent history, we have seen a still greater inequity in the authority given to Nevada with 70,000 inhabitants to control through its two senators, a decision of the Senate and through the Senate of the whole Government, in regard to a financial policy to which the great states of the country were opposed.

Jefferson was, in $\mathrm{I} 787$, appointed U. S. Minister to Paris, and the latter portion of the Diary is taken up chiefly with his account of the beginnings of the French Revolution and his analysis of the causes and events.

The students of American history will not fail to bear in mind the long contest between the advocates of a strong, or at least a sufficiently strong, 
central government, of whom Hamilton was the leader, and those who, apprehensive of the tyranny of a central authority, preferred to maintain the full independence of the states, even at the sacrifice of National power and effectiveness - a group of which Jefferson was the acknowledged representative.

The constitution of 1789 , carried through the influence of Hamilton, represented important concessions made to the views of the Jeffersonians, some of which had troublesome results in the later history of the Republic. I may mention, among others, the including of slaves in the proportion of three slaves to two white men in the basis of representation for the slave-holding states; the acceptance of a site on the banks of the Potomac, that is to say, in Southern territory, for the new Capital. The power given to the slave holders in Congress through the counting of the slaves as if they were a part of their voting constituency, resulted in strengthening through the long series of years, the authority of the South in the House of Representatives, and delayed any effective action on the part of the Free states in bringing about the restriction of slavery. The position of Washington on the banks of the Potomac brought about no small difficulties later in the shaping of the campaigns of the Civil War. The necessity for the protection of the Capitol interfered materially with the action of the armies of the North and must have delayed for a long period of months the final decision of the contest.

The results of the Civil War brought the Nation to a substantial acceptance of the theories of Hamilton. 
The Government as developed under the I 3 th, I 4 th, and 15 th amendments to the Constitution, was made strong enough to control peace at home and to maintain the authority and dignity of the Nation abroad. The occasional difficulties arising from independent state action, such as that of Louisiana eighteen years back in its friction with Italy, and that of California during the past few years in its state laws affecting the interests of the Japanese, are examples of what is probably the last remnant of the Jeffersonian theories of state rights. The American citizen of to-day is unwilling to believe that any right of action should be left to the state that can interfere with obligations and international relations of the National Government. The fact, however, that certain, and probably the more important, of Jefferson's theories, having been fairly tested, have been put to one side, or have been fought to one side, does not prevent the citizen of to-day from holding in affectionate regard the author of the Declaration of Independence who, through his distinguished services, and his high ideals is to be ranked among the greatest of American citizens.

G. H. P.

NEW YORK, January 1914. 


\section{INTRODUCTION}

The political theories and usages originated or adopted by Thomas Jefferson have shown such persistence and permanence in their value to our people and government as to demonstrate a far deeper and broader principle underlying them than is always recognized. In popular estimation, Jefferson stands as the founder of the Democratic party, and the developer of the theory of State Rights; and on these foundations are based the so called "Jeffersonian principles," and the respect and acceptance, as well as the criticism and contravention, accorded to them. That this basis was deemed sufficient during his life, is natural, for judgment of a living man must always be partial and superficial. That this limited view should during that time acquire prestige and momentum enough to project it into history, is not strange, the more that the logical conclusions of certain theories advanced by him suited the policy of one of our political parties. The acceptance of this limited view has enabled his antagonists and critics to charge him with hypocrisy, opportunism, and even lack of any political principles; and the contradictions and instability they have cited in his opinions and conduct have 
embarrassed even his most devoted adherents. If this limited view is still to be accepted as sufficient anc final, these criticisms must stand:- His advocacy of a weak national government; with his complaints that it was "a rope of sand," and his far-reaching augmentations to its power. His advocacy of a strict construing of our constitution; and yet his so exceeding the implied powers granted by it, as to make it, in his own words, "waste paper." His support of the State governments as "sovereign"; and his dislike and attempted changes in and overriding of their constitutions. His arguments in favor of an absolutely independent jury and judiciary; and his attacks on both. His desire for a national navy; and his later opposition. His demands that the executive and legislative departments should be beyond reciprocal influence; yet, when president, his interference in the latter to an extent which led to a stinging rebuke on the floor of Congress in open debate. His dread of a partizan civil service as a means of influencing and defeating free elections, and his oft repeated claim that public officers should be selected only on their merit; while himself inaugurating the spoils system, sending his political friends commissions in blank, and retaining a federalist official "because of his connections." His disapproval of the re-eligibility of the president, and advocacy of rotation in office to prevent the creation of a bureatucracy; with his subsequent willingness that the former should serve more than two terms, and his writing to a superannuated appointee, "would it be a relief to transfer the office to your 
son, for your use, with the understanding that it should be afterwards continued with him for the benefit of the family?" His opposition to the alien act; and his framing of a bill directed against foreigners of far greater injustice than that enactment. His support of the passage of the funding and assumption act; and his unending opposition to its execution. His condemnation of the national bank, not merely on constitutional grounds, but because he believed it to be unduly influencing the national government; yet when himself at the head of that government advocating "a judicious distribution" of favors to that and other banks " to engage the individuals who belong to them in support" of his administration. His early opposition to national internal improvements, his later recommendation of this policy to Congress, and his final resolutions declaring it unconstitutional. His arguments and labors in opposition to slavery; while owning many negroes, and refusing to act as executor of a will because the testator freed his slaves-And many other actions apparently implying so little principle, or views so shifting, as superficially to reduce them to nothing else than a mass of inconsistencies, each one notable only for its immediate results. Judged by these standards, the marvel of the Federalists and his later critics, that he should have been the chosen instrument of American democracy, is proper. The scholarly and reclusive nature of his tastes and studies; the retiring and limited character of his intercourse with the world; the influence of his social equals; his dislike of party and personal 
antagonism; and his sensitiveness to abuse and criticism, make his acceptance of that leadership, as strange a problem, as that the people should have chosen for their representative a man lacking nearly all of the personal qualities which are presumed to win popularity with the masses. And only explicable from the narrow view of his critics as the success of an ambitious and unprincipled self-seeking man, attained by astuteness and chicane so great as to deceive the masses.

But if the people embody the total of human thought and experience, as our political theories maintain, there are better reasons than these for his elevation, and for the political influence his name has carried for over one hundred years-better reasons than the leadership of a party, or a fine-spun theory of the respective powers of the state and national governments. The explanation of these apparent anomalies lies deeper than any mere matter of individuality, party success, or rigid political platform. To understand why Jefferson became "a man of the people," and for what reasons and purposes they made him their leader, we must study certain forces and tendencies then working in America.

In the never-ending struggle between the so called "classes" and "masses," not the least interesting. phase is that which occurred in the revolutionary period in this country. Although the colonies were nominally royal appendages, legislated for by King and Parliament, the difficulties of governing at such distance and other conditions, had compelled the 


\section{Introduction}

granting to them, or an acquiescence in their exercising, a large degree of local self-government. In conceding this, the attempt had been made, and in most cases successfully, to place power in the hands of the classes; so as to build up a colonial aristocracy, subservient to the wishes of the mother country. And as the colonies grew and became objects of greater interest to Great Britain, this tendency became more and more marked. But the conditions of the country were not suited for class or centralized government. The wilderness made every man a land-holder, and the vast extent of territory and its sparse settlement rendered civil authority unable to exercise its force, and therefore hardly a factor in its influence on the people. Yet the lawlessness of the new settlements, and the Indians on the frontier, compelled the maintenance of some kind of authority, and so each settler, and each community, became largely the law-maker and administrator of their own affairs. Thus it was that local selfgovernment, based solely on manhood, was tested and became the cardinal principle of American government.

Such was the trending development of the people, when the policy of England between I 764 and I 775 , towards her American colonies, united them in opposition to her rule. That opposition, and the great movement towards democratic government, were by events so blended, that they have since stood as one in the public mind. Yet they were entirely different, most of our great revolutionary leaders deprecating the latter; and while events converted some 
few to the democratic theory of power, the majority never ceased to fear the people. Had it not been for the exigencies of the war, which compelled an appeal to the masses, to destroy the royal government, and to fight the mother country, it is probable that they would not have gained any political power from national independence. But in the interregnum between the destruction of the old and the creation of the new governments, much was gained, not merely in actual exercise of rights, but in experience; for the masses learned that self-organized bodies of men, acting under no legal authority, could rule a whole country by mere recommendations; that a dependent government is the strongest in the world, for it must accord with public opinion, and therefore meet with public support; that constitutions and laws are but ink and paper unless they approximate to that sole origin of force and authority; and that it is not the government which supports the people, but the people who support the government.

The masses are by their nature and condition, however, negative rather than positive, and when constructive, rather than destructive or obstructive force is required, they are compelled to delegate a portion of their powers. Thus, in the re-building of government, the classes secured an influence far out of proportion to their numbers. In the State constitutions, they succeeded in somewhat curtailing and limiting the popular control; and later, in the formation of our national constitution they sought still further to wrest powers from the people, both by grants, which interposed barriers to the direct dele- 
gation of power from the people to the executive, judiciary, and one of the legislative branches, and by clauses purposely worded so as to leave the question of the quantity of power granted to the decision of men who would almost certainly be drawn from the classes. And a resulting political party attempted to carry this policy still further. Had government been merely a matter of intellect and ability, the Federalists would have succeeded in controlling and fixing its character in this country. That when they had done their work of construction, they were excluded from office, without ever comprehending the reason, proves how little they understood the tendency, intelligence, and power of the forces they were attempting to circumscribe. Unlike the Federalists, Jefferson was willing to discard the tradition of ages - that the people must be protected against themselves by the brains, money, and better "elements" of the country - and for this reason American democracy made him its chosen agent and mouth-piece.

To understand why Jefferson was one of the few men of intellect of his time able to appreciate, sympathize with, and aid this popular movement, a retrospect of certain factors in his life and times is necessary. Inheriting unsettling tendencies of mind, he was from an early age a thorough skeptic of tradition and precedent. In his own words, he never "feared to follow truth and reason to whatever results they led, and bearding every authority which stood in their way." Almost alone of the revolutionary leaders, he was born on the frontier, which, 
as already stated, was the ultimate of local selfgovernment. Among those conditions he passed the formative period of his life, and as representative of this district he made his first essay in politics, naturally as an advocate and defender of the democratic mountaineers. In the Virginia Assembly, in which his earliest battles were fought, the strongest line of party division was between the aristocratic "planter" interest-great landed and slave-holding proprietors, with the prestige and inertia of favorable laws and offices-and the "settler" interest-inhabiting the frontier, far from the law or protection of government, but strong in numbers, independence, and necessities;--and in these conflicts he learned how absolutely selfish and grasping all class legislation is. Then came the Revolution, and Jefferson saw governments, deriving their authority from laws innumerable, and their force from the strongest nation of Europe, utterly destroyed, with hardly a blow, merely through their non-recognition by the masses. With the Committees of Safety and the Congresses which succeeded, he saw the experiment of "a government of the people, by the people, for the people," established and tested. Had he been in America between I 784 and i 788 , he too might have become doubtful as to how far the masses could control themselves, for the reaction of the revolutionary struggle was severe, and strained democratic institutions almost to anarchy. But at this time he was in France, witnessing another great struggle between the privileged and unprivileged. So he returned to America, true to the influences and lessons 
of his life, to find his theories in disfavor with the conservative, and government slipping more and more from the control of the governed. And because he believed that only the people truly knew what the people needed; that those who could take carc of themsclves werc wise and practical enough to help care for the nation; and that the only way of enforcing laws was that they should be made by those who are to obey them, he undertook, with reluctance and self-sacrifice, to be the instrument of popular action. That he was the founder of the Democratic party is a claim little less than absurd, for there always has been, and always will be, sttch a party. But he united the democratic elements on certain principles and objects, and proved himself such a leader as the party has seldom been able to obtain.

Recognition of what he endeavored to accomplish explains many of his apparent inconsistencies. The dominant principle of his creed was that all powers belonged to the people, and that governments, constitutions, laws, precedent, and all other artificial clogs and "protections," are entitled to respect and obedience only as they fulfilled their limited function of aiding - not curtailing - the greatest freedom to the individual. For this reason, he held that no power existed to bind the people or posterity, except by their own acts. For this reason, he was the strict construer of the national constitution, where he believed it destructive of personal freedom; and construed it liberally where it threatened to limit the development of the people. He was the defender of 
the State governments; for he regarded them as a necessary division for local self-government and as natural checks on the national power, and so a safeguard to the people. That he appealed to them in his resolutions of 1798 , was because he believed the people for once unable to act for their own interest, and the theories of that paper are a radical and short-lived contradiction of his true beliefs. Because he believed the national judiciary and the national bank to be opposed to the will of the people, he attacked them. Because he believed he was furthering the popular will, he interfered in the legislative department and changed office-holders. Because he wished them free to think and act, he favored separation from England, abolition of slavery, free lands, free education, freedom of religion, and the largest degree of local self-government. His methods and results were not always good. His character and-conduct had many serious flaws. Yet in some subtle way the people understood him, and forgave in him weaknesses and defects they have seldom condoned. And eventually this judgment will universally obtain, as the fact becomes clearer and clearer, that neither national independence, nor state sovereignty, with the national and party rancors that attach to them, were the controlling aim and attempt of his life; that no party or temporary advantage was the object of his endeavors, but that he fought for the ever enduring privilege of personal freedom.

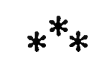


The proof for this view of Jefferson must be sought in such of his writings as are still preserved:

In the Foumal of the House of Burgesses of Virginia for May 9, I769, are a series of resolutions intended to serve as a basis for the reply of that body to the speech of their newly arrived governor. Remarkable here only for their intense obsequiousness and adulation, these resolutions merit notice as the first public paper drawn by Thomas Jefferson. As a lawyer, however, Jefferson was already known. Few of his arguments have been preserved, but these few give evidence that he was already out of spirit with his surroundings. The man who could argue that human servitude was "a violation of the law of nature", that under those laws, "all men are born free, every one comes into the world with a right to his own person, which includes the liberty of moving and using it at his own will" ; and that "Christianity neither is nor ever was a part of the common law," was clearly not in sympathy with a slave-holding community, living under an established church, and ruled by a royal governor.

His next public paper was of much the same form, though differing greatly in nature from his first. It was a series of resolutions intended for the guidance and adoption of the self-constituted convention which met in August, I774, and the difference in tone almost tells the history of those intervening years. Then, the interests of England and America were "inseparably the same." Now, only by accepting the advice of these resolutions could the "reciprocal advantages of their connection" be 
preserved. The power of Parliament over the colonies was denied; the King instructed that he was " no more than the chief officer of the people, appointed by the laws, and circumscribed with definite powers, to assist in working the great machine of government erected for their use, and consequently subject to their superintendence"; and the assertion made that the American people possessed the sole power of self-government and could "exercise it to an unlimited extent." These opinions were too extreme for even a revolutionary convention, but they nevertheless formed one more stepping-stone in the direction of independence for the colonies.

A year later he wrote the reply of the Virginia House of Burgesses to the plan of reconciliation known as Lord North's " Motion," and was the bearer of it to the Continental Congress, of which he had been elected a member. For this body, he likewise wrote a second reply to the "Motion," as well as a "Declaration" on the United Colonies taking up arms. But this latter did not meet with their approval, and one prepared by Dickinson was taken in its stead; and a comparison of the two certainly justifies the Congress. He also drafted a number of minor papers for that body, and prepared a plan for an executive govermment by a committee of Congress-an attempt not then realized, but which was later in an elaborated form to be again proposed by Jefferson, to be tried, and to result in failure.

In the Congress of 1776 he drafted, for the committee of which he was a member, three reports dealing with Canadian affairs, which are now of interest 


\section{Introduction}

only from the light they throw on the attempt to conquer that country. While so occupied, he drafted a proposed constitution for his native state and forwarded it to the convention in hopes of their accepting it, which they failed to do. But it is for us a most interesting papcr, as illustrating the development of his political theories, the most notable being his acquiescence in the limiting of the franchise to freeholders, well knowing as he did, the impossibility of gaining from the aristocratic party any extension of the ballot, but neutralizing this acquiescence by distributing the public lands so as to make a manhood suffrage; his far-seeing method for dealing with western colonization, his proposed ending of primogeniture, test oaths, and the slave trade; and his guarantees of freedom of religion and press. He prepared a number of other reports and resolutions for Congress, the most worthy of notice being his rules for the government of that body, which was probably the first step towards his parliamentary manual. His greatest work, however, was the writing of a vindication of the resolution of independence, since poptlarly known as the "Declaration of Independence." Jefferson never forgave the alterations which the sectional interests, as also the better sense of the Congress, made in his draft, even though they were for the most part omissions of what lacked either truth or dignity. The fame of the paper, which is probably the best known that ever came from the pen of an individual, has led to much discussion as to its origin, and numerous charges of plagiarism have been made against the 
author. That the catalogue of wrongs and grievances which constitute the body of the declaration was hackneyed is beyond dispute, for these had formed the basis of nearly every address and petition put forth by the Continental Congress, or Provincial Assemblies, and had been as well the prevailing subject of written and verbal discussion. The preamble and exordium are however the important parts. A comparison of the former with the Virginia Declaration of Rights would seem to indicate the source from which Jefferson derived a most important and popular part. The latter was practically rewritten by Congress. But the unity and phrasing of such a paper constitute no small portion of its composition, and to embody the feelings and hopes of a new nation in a single paper, as Jefferson did with such marvellous success, makes it unique among the greatest writings of the world, and gives to him an honor that can never end. With the Declaration of Independence the Congress completed a change which had been slowly maturing. From being a scribe of petitions and declarations, it tended more and more to become a war executive, and Jefferson, who achieved reputation by his philosophic mind and pen, and who himself realized his lack of ability in administration, found himself of little use in such a body. Pleading family and other reasons, therefore, he retired from Congress and took his seat in the Virginia House of Delegates.

The great problem here was a rebuilding of civil government destroyed by the Revolution. A constitution had been adopted, and under this a legisla- 


\section{Introduction}

ture and executive had been elected, but courts and laws had fallen with the royal government, and to re-establish them in modified form was the task to which Jefferson set himself. With the permission of the legislature, and in conjunction with two collaborators, he worked for nearly three years upon a complete code, and reported it to that body; which from time to time adopted certain features from it, but neglected the larger part. In addition to this great work, he drafted, during his service in this body, many bills of immediate or temporary moment. This was done in a period almost without precedent, when it was necessary not merely to carry on the ordinary forms of government, but to conduct a war in distant states and territories, and repress disloyalty and lawlessness within the limits of the state. And he was thwarted by parties and cliques formed on geographical lines, religious beliefs, and class feeling, and rent by personal hatred and cabal. It is therefore small wonder that he aided in some unjust and even unconstitutional legislation, or that much of his that was good should fail. But his proposed bills for religious freedom, for the creation of public schools, and for the establishment of free libraries more than redeem his errors. His legislation contributed more than the work of any other man to free the aristocratic colony of Virginia from the "planter" interest and start it towards democratic statehood; and the Assembly proved that he had labored to their satisfaction by electing him Governor.

In an executive position, Jefferson was out of his 
element. Nothing was called for or came from his pen but official letters and proclamations. His administration produced open murnurs, and at the end of two years he sought relief in resignation, with the stigma of incompetence, if not of cowardice, the prevailing opinion concerning him. Impeachment was attempted without success; and later, when the evils begun in his term had been overcome, whitewashing resolutions were adopted by the legislature in his behalf; but they brought no relief to his own supersensitiveness, and he hid himself in an almost hermit-like seclusion from the world, determined never more to hold public office.

Here he prepared for the information of the French government his famous Notes on Virginia. Intended for confidential use only, and written during a period of personal bitterness, it is most interesting from its outspoken tone on many subjects. But even more notable is the remarkable mass of information he gives concerning the State; which after a lapse of more than one hundred years still makes it a valuable work of reference. During the same period he wrote an essay on the Art of Poesy, and prepared a second proposed constitution for Virginia, which illustrated the tendency of his mind since he had drafted his first in 1776 , the most marked departure being his direct attempt to extend the franchise.

Drawn from his retirement by the hope of a foreign mission, the importunities of his friends induced him to accept an election to the Continental Congress. In his less than six months' service in this body, the 


\section{Introduction}

$\mathrm{xx} \cdot ;$

amount and importance of his work can hardly be overestimated. He was a member of almost every important committee appointed, and no less than thirty-one papers were drafted by him. He proposed and carried a plan for a committee of Congress which should sit during adjournments. He drew the report and instructions for negotiating commercial treaties with European states, in which he embodied his humane desires that fishermen, farmers, and artisans engaged in their vocations should not be subject to capture; that undefended towns should not be injured; that privateering should cease; and commerce, even between belligerents, should be free. His reports on the finances were most elaborate and careful, and in connection with these he prepared his Notes on a Money Unit, which led to the adoption of the dollar as our standard of value, and in which he was far-seeing enough to argue that " the true proportion of value between gold and silver was a mercantile problem altogether," and that it was policy " to give a little more than the market price for gold because of its superior convenience in transportation." But his greatest work was in reference to the western territories. His pen drafted the cession which Virginia made to the national government, and, conscious that this "was the time when our Confederation with the territory included within its limits should assume its ultimate form," he framed a plan of government for all the territory outside the boundaries of the original states. The effect of the clauses making this territory forever part of the United States and ending slavery in it after the year 
I 800 , would have solved our greatest political contest, but these are of small moment when compared with the system here for the first time established, that the inhabitants of the public domain were not to be held as subject colonies, but were to be given equal rights with the parent state. No one enactment has had so vital an influence on the American Union; and this principle was extended by another ordinance, proposing a land system, which must be considered as the first of the national acts towards distributing the public lands among the people.

Sent to Europe in 1784 to aid in negotiating treaties, and a year later made Minister to France, he wrote little in the few following years, other than official letters. He contributed a few anonymous articles to the Paris papers to counteract the published criticisms of America, and at the request of the authors carefully corrected certain historical works on the same subject which were then appearing. In his diplomatic function he proposed to the several European nations an agreement to restrain, by united action, the piratical states of North Africa; drafted a proposed Consular convention with France; and prepared a careful and minute mémoire on the American whale fisheries, with the purpose of obtaining from France special exemptions in favor of the oil sent from America. In addition, his deep interest in the French Revolution led him to overstep the proper limits of his office, and prepare a "Charter of Rights" which he desired should be adopted by the States-General.

Returning to America, he became Secretary of 
State in Washington's administration. His position resulted in a diplomatic correspondence and a series of reports to Congress on subjects referred to him. But of more interest are his cabinet opinions and the messages he drafted for the President. Gradually growing out of sympathy with the acts of the Executive, he likewise recorded passing events and opinions in notes, which have since become famous under the name of "Anas." Later in his life, he himself judged it expedient to revise and suppress portions of these notes, and his editors took further liberties with them. Yet even after this double revision, they were not printed without apologies and regrets that they had ever been written.

Retiring from the cabinet in $\mathbf{I} 794$, he resumed a planter's life, and during this period, his pen produced nothing, unless we except some curious "Notes for a Constitution" for Virginia. Having reference only to the legislative branch, they are too imperfect to be of value, except as a contrast to the methods suggested in his proposed constitutions of $I_{77} 6$ and ${ }_{1} 783$.

Elected Vice-President in 1796 , and so made presiding officer of the Senate, he prepared his Mamual of Parliamentary Practice, ehiefly drawn from the rules of Parliament, as well "to have them at hand for my own government, as to deposit with the Senate the standard by which I judge and am willing to be judged." In this same period, he wrote an essay on Anglo-Saxon; a memoir on the discovery of certain bones of an animal in the western parts of Virginia; and a description of a mould-board of the least resistance for ploughs. He also drew a 
protest for his district against the act of a grand jury, employing in it a train of argument, which, put in practice, would have ended the independence of juries; and prepared a series of resolutions for the Kentucky legislature, which mark the culminating point of certain political tendencies that had been developed by the administrations of Washington and Adams. The platform of a party for many years, they have become famous not merely for the theory, but for the logical results of the theory, which history has given us. The Kentucky Resolutions of ' 98 were, however, prepared by Jefferson as a piece of party manœuvring, he himself acknowledging that the direct action of the people rather than the interference by the states, was "the constitutional method"; and he so thoroughly understood the destructive quality of his argument that he worded it "so as to hold that ground in future, and leave the matter in such train as that we may not be committed to push matters to extremities, and yet be free to push as far as events will render prudent." In fact, nullification of Federal, not national acts, was his object in those resolutions.

Raised to the Presidency in $180 \mathrm{I}$, he wrote many messages and other public papers; drew a number of bills and resolutions for Congress to pass; compiled an elaborate treatise on the boundaries of Louisiana; contributed a series of articles to a newspaper vindicating certain of his actions which had met with criticism; and partly drafted a curious monograph on the question: "Will the human race become more perfect?" The latter typical of his optimism, for when 
all Europe was in arms, and his own country suffering many evils, he could yet argue strongly in favor of a steady progress towards perfection.

After his retirement from office in 1809 , he wrote a "plan of an agricultural society," which is of little importance; sketched a paper on "objects of finance, intended for the guidance of the national government in the difficulties already felt, in which he argued strongly against all forms of fiat money; drew a brief fur the government relative to certain riparian rights; prepared at various times biographical notes and sketches of Franklin, Wythe, Peyton Randolph, and Meriwether Lewis; planned and partially outlined a work to be entitled The Morals and Life of Fesus of Nazareth; prepared an Autobiography to the year I790; framed another series of resolutions opposed to the action of the national government; and finally, owing to press of financial difficulties, and in behalf of a private scheme for his own advantage, wrote vigorously in favor of lotteries.

In addition to these, and a number of minor paper's, Jefferson carried on between the years of $1 ; 60$ and i 826 an enormous correspondence, both private and official, which practically constitutes the greater mass of his writings. A careful estimate of the letters still in existence gives not less than twenty-five thousand, yet portions only of certain years are still extant. Interesting not merely for the opinions expressed, but for the personal element they present, they are of equal, if not superior, importance to his other writings.

$$
*^{*} *
$$


The first of these writings to appear in print was the resolutions prepared for the Virginia House of Burgesses in I 769 , which was printed in their Fournal for that year. In I 774, without his knowledge, his friends caused the printing in pamphlet form of his proposed instructions to the Virginia delegates to the first Congress. His reply to Lord North's "Motion" was printed in the Fournal of Congress for 1775 , and very generally in the newspaper press of that year. His Declaration of Independence ran through the colonies like willfire, in many printed forms. Such bills as he drafted, which became laws, were printed in the session aets of Virginia during the years i 776 to 1779 . Several of his reports in the Corngress of $178,3-4$ were printed as broadsides, and he himself printed in the same form his Notes on a Money Unit. In I 784 , the State of Virginia printed, in the Report of the Revisors, the laws he had prepared for the proposed code. And, in the same year, he himself privately printed his Notes on Virginia and his Draft of a Fundamental Constitution for Virginia. In 1788 , his $O b$ servations on the Whale Fisheries, and the Consular Convention he had agreed upon with France, were printed. Most of 1iis reports to Congress as Secretary of State, and a part of his corresponclence with the foreign governments, were printed at various times between I 790 and r 794 , by orler of Congress. His Kentucky Resolutions of I79s were, in their amended form, given print and general currency by that state. His Manual of Parliamentary Practice was originally printed $1, y$ request in ISoo, and has been many times reprinted. In r8oo, he published 


\section{Introduction}

his Appendix to the Notes on Virginia, which was later issued as a part of that work. His inaugural speeches and messages as President were published in various forms as they became public. The argument he prepared on the Batture case was issued in pamphlet form in 1812 . His biographical sketch of Lewis was printed in 1814 in the History of the Expedition of Lewis and Clark. A volume of legal reports, containing three of his early law arguments, edited by him before his death, was issued in I 829 . In the same year, his grandson, Thomas Jefferson Randolph, as his literary executor, edited a fourvolume edition of his writings and correspondence, including his autobiography, a small portion of his private correspondence, a part of his Anas, and a few miscellaneous papers; which was several times reprinted. In 1851, his Essay on Anglo-Saxon was printed by the University of Virginia, and five years later, his correspondence relating to that institution was included in the History of the University of Virginia. In 1848 , Congress purchased the larger part of his papers, and by their direction, H. A. Washington selected from tinem, with a few additions from other sources, enough to make a nine-volume edition of his writings, which naturally became the standard collection.

\section{Paul Leicester Ford.}

October $15,1892$. 



\section{PUBLISHERS' NOTE}

The publishers have thought it in order to utilize for this re-issue of Jefferson's Autobiography the Introduction prepared by the late Paul Leicester Ford, for the Federal Edition of Jefferson's Works.

In this volume only the closing paragraph, which refers to the sources from which he collected the material comprised in the complete works, has been omitted from Ford's Introduction. 



\title{
CHIEF EVENTS IN JEFFERSON'S LIFE
}

\author{
FROM HIS BIRTH IN 1743 TO HIS DEATH IN 1826
}

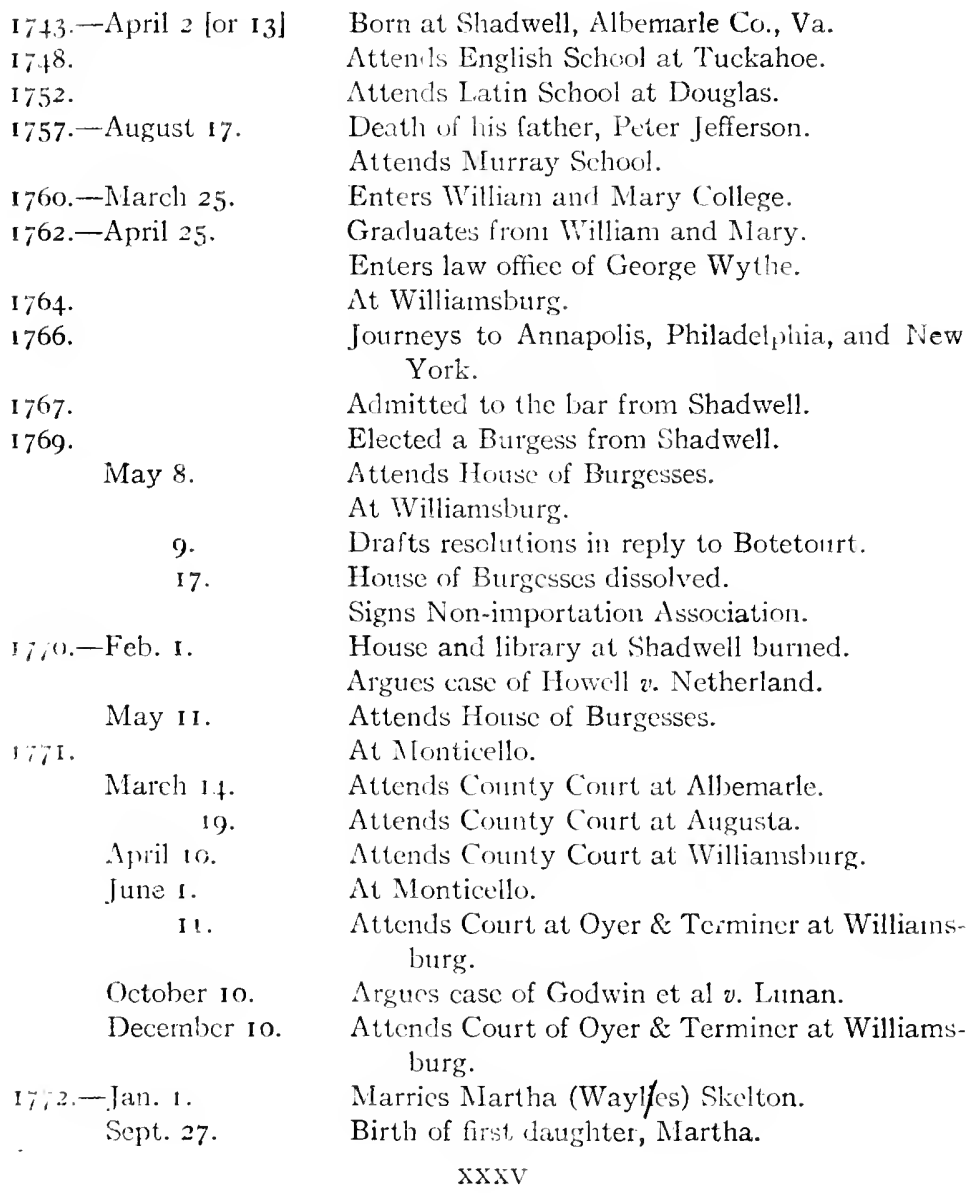


$1 \% 5 .--$ Marcl1 4.

I 2.

October 14.

$1774-A$ pril 3 .

May 9.

July 26.

$1775 .-\mathrm{Jan} .5$.

March 20.

23.

27.

fune 2.

10.

21.

July 3!.

Augn: 9.

II.

16.

() toher 2 .

Nov. 16.

2.3 .

24.

Dec. 15.

22.

$1776 .-\mathrm{March} 31$. May $2 \mathrm{I}$.

June z.

5.

Io.

I1.

$\mathrm{I} \%$

20 .

$2 S$.
Attends House of Burgesses at Williamsburg.

Aitends Committee of Correspondence.

Appointed Surveyor of Albemarle County.

Birth of second daughter, Jane Randolph.

Attends Honse of Burgesses.

Drafts the resolutions of $A$ ibemarle Co.

Writes "A Summary View."

Elected nnember of Albemarle Committee of Safety.

Attenel: Convention at Richmoncl.

Placer on Committee for I)efense of Colony.

Elected deputy delegate to the Continental Congress.

On Committec to Draft Address to the Governor.

Prepares address to Governor Dunmore.

Attends Continental Congress at Philadelplia.

Placed on Committe to 1)rali Declaration on

Army and Prepares lraft.

Reports from Committe Draft and Reply to Lord North's Motion.

Attends at Richmonl Convention of $\mathrm{Va}$.

Reellecter member of Continental Congress.

Placed on Committec on 1)efense.

Attends at Philadelphia session of Continental Cingress.

Ilaced on Committe on Mlassachusetts Papers.

rlaced on Committec on Currency.

l'laces on Committee on Condition of $\mathrm{N}$. C.

Prepares rules for Committee of Congress.

Placel on Contunittec on Business of Congress.

Deatle of Jefiersun's mother.

Draft of Report of Congressional Committee on letters.

Placed on Committee to Address Foreign Mercenaries.

Drafts: Constitution for Va.

Placel on Committec for Procuring News and supplies.

On Committer to Propare Rules for Congress.

On Committe to Irepare Declaration of Independence.

Draft Report of such Committee.

Reelected nember of Congress.

Draft Repurt on Canada.

Reports draft of Declaration of Independence. 


\section{Chief Events in Jefferson's Life xxxvii}

I776.-Duly \&.

5.

6.

Aug. 9.

Sept. 26.

Oct. I I.

15.

16.

21.

2.5 .

28.

Nov. 6.

$i$.

II.

$1777 .-$ Dec. 1.3.

$2 \pi$

T7,8.-.Jan. 20.

May 18 .

June 10.

Aug. 1 .

$1779 .-$ Jan. 22.

Nov. $3 \%$.

I780.--June 1.

Nov. 3.

Dec. 31 .

1781 .- Jan. 2.

Feb. 5.

April 15.

June $I$.

I.4.

July.

Nov. $3 \%$.

Dec. 10.

19.

$1782 .-$ Sept.

6.

Nov. 12.

Dec. 19.
Adopted Declaration.

Placed on Committee to Plan Seal for U.S.

Placed on Committec on Indian Affairs.

Placed on Committee to Encourage Hessians to Desert.

- Elected Commissioner of France.

Placed on Committee on Propositions and Grievances.

On Committee on Privileges and Elections.

On Committee to Draft Infantry Bill.

On Committee to Drafi Punishment Bill.

On Committee to Draft Bill to Renove Seat of Government and on Committec to Draft Naturalization Bill.

On Committee to Draft Congress Bill.

Ch Committee to Draft Bill to Define Treason.

Chosen one of five 10 revise the laws.

On Committee to Draft Copper-Coinage Bili.

Introrluces Bill to Remove Capital.

On Committee to Draft Tax Bill.

( ) Committec to Draft Salary Bill.

On Committee to Amend Small-Pox Bill.

On Committee to Draft Chancery Court Bill.

On CommittectoDraft Bill forRecovery of Debts.

Leaves Williamsburg.

Third daughter born (Mary Jefferson).

At Williamsburg.

Issues Proclamation Laying Embarso.

Reēlected Governor of Virginia.

Birth of fourth daughter.

Receives news of Leslie's Invasion.

Orders out militia.

Issues Proclamation Concerning Forcirners.

Death of son.

Resigns (ivvernorship.

Appointed by Congress Peace Commissioner, which appointment he declines.

Begins preparation of Notes on Virginia.

Elected delegate to Contincntal Congress.

Placed on Committee on Finance.

Declines appointment for Congress.

Birth of youngest daughter, Lucy Elizabeth.

Death of wife.

Appointed Pcace Commissioner to Europe.

Arrives at Philadelphia. 


\section{xxxviii Chief Events in Jefferson's Life}

1783.-Fcb. 14. April I.

June 6.

I0.

Nov. 4.

Dec. 16.

22.

27.

1784 . -Jan. It.

March I.

5.

12.

I. 3.

April 5 .

30.

13.

May 3.

23.

July 5 .

Aug. 6.

IO.

Sept. I3.

I .5.

16.

I785.-March Io.

Nay $1 \mathrm{I}$.

July 28 .

Novemher.

I $786 .-$ March 5 .

22.

23.

26.

May 23.

Oet. 22.

Dec. 16 .

26.
Departure to Europe suspended.

Congress withdraws appointment.

Eiected delegate to Congress.

Drafts Constitution for Virginia.

Congress adjourns to Annapolis.

Reports on definitive treaty.

Reports on cercmonial for Washington.

Reports on ratification of treaty.

Reports Proclamation of British Treaty.

Reports on Government for Western Teritory.

Reports on Indiana.

Elected Chairnan of Congress.

Placed on Committee on Qualifications and on Foreign Letters.

Elucted Chairman of Congress.

Prepares Notes on a Noney Unit.

Drafts resolution concerning seat of Government.

Reports ordinance for Trestern lands.

Report on W'estern Territory considered and adopted.

Sails from Boston on ship Ceres.

Reaches Paris.

At Passy, conferring with Franklin.

Sends the first Notes on Virginia.

At Versailles, with Commissioners, to meci Vergennes.

The Commissioners meet the British Ministers.

Elected by Congress Minister to France.

Completes Notes on Virginia.

Signs treaty with Prussia.

Death in Virginia of the youngest daughter, Lucy Elizaheth.

Lcaves Paris for London.

Presented at Windsor to the King.

Negotiates treaty with Portugal.

Prepares with Adams projet of treaty with Great Britain.

Plans treaty against Barbary States.

Prepares map of Virģinia.

Act of Religious I'redom passed by the Virginia Assemily.

Publication of French version of Notes on Virginia. 


\section{Chief Events in Jefferson's Life xxxix}

I787.-Jan. 4. Makes proposition to British creditors.

April, May, June. Tour through Franee.

Sept. Finishes map of Virginia.

Dec. Publication in England of " Notes on Virginia."

1788.-Feb. 4. Leaves Paris.

II. Declines membership in Society for Abolition of Slave Trade.

April

June 20.

I 789.-May 8.

June 3 .

July $\mathbf{1} 7$.

Sept. 25 .

26.

Oct.

1790.-Feb. 14.

28.

March 29.

June 7 .

July 4.

Aur. 22.

26.

28.

Nov. 2 I.

Dec. 8.

I79I.

Feb. I.

I5. 28.

May.

July.

1792.

Journcy to Germany.

Reccives from Harvard degree of LL.D.

Attcnds the opening at Versailles of the StatesGeneral.

Prepares charter for France.

Views ruins of Bastille.

Jefferson nominated for Secretary of State.

Confirmed by Senate.

Saits for America on the Montgomery.

Aecepts Secretaryship of State.

Arranges with Dutch bankers for a tuan.

Marriage of Jefferson's daughter Martha to Thomas Mann Randolph.

Takes residence in Maiden Lanc, New York City.

Elected member of American $\Delta \mathrm{rts}$ and Scicnces. Arranges with Hamilton the Assumption and Capital Compromise.

Reports on coinage, weights, and measures.

Drafts Considerations on Navigation of Mississippi.

Opinion on Foreign Debt.

Opinion on course toward Britain and Spain.

Takes residence in Philatelphia.

Draft of paragraph for President's Message.

Prepares Report on Fisheries.

Reports on Algerian Prisoners.

Draft of President's Message on British Negotiations.

Opinion on National Bank.

Offers Freneau a place.

Endorses Paine's Rights of Man.

Arranges with Frencau for the publication of a paper.

Endeavors to have Thomas Paine appointed postmaster.

Draft of President's Message on Diplomatic Nominations. 


\section{$\mathrm{xl}$

1792.-Feb. 28.

May 23.

Sept. 9 .

1793.-Jan.

Feb. 7 .

$\Lambda$ pril 8.

18.

Nay 8.

July 5 .

8.

Aug. 2.

31.

Nov. 16.

23.

Dec. $3 \mathbf{I}$.

(201.-Sept.

1795.-Dec.

$1796 .-$ Nay 12.

Nov. 4.

17) 7 - -Jan.

I 797.- -Jan. 25.

March \&.

May 14.

Oct. 13 .

1798.- - 1ich. 19.

Jialy 6.

()et.

14.

Nov. 14.

15 .

(1.)10.--Ja11. 18.

F(i).

May.

June.

Dec. 14

191.-. - Pa. 17.

18.
Announces to President intention to leave office. Writes to Washington of intended resignation.

Writes to President in defense of conduct.

Reconsiders resignation.

Paper on maladministration (by Hamilton) of the Treasury.

Genet lands at Charleston.

Drafts Cabinet Opinion on Proclamation and French Minister.

Opposes Hamilton's circular to collcctors.

Receives call from Genct.

Dissents from Cabinct Opinion on Little Sarah.

Recall of Genet decided upon by the Cabinet.

Drafts Cabinet Opinion on Privatcers and Prizes.

Borrows money.

Drafts Message to the Presiclent.

Resigns Secretaryship of State.

Offer of forcign mission.

Invents mould-board for plough.

Executes nortgage on his honte.

Elected Vice-President.

Elected President to Philosophical Socicty.

Letter written to Mazzei (in 1796 ) printed in Paris.

Sworn in as Vice-President.

Offer of French Mission.

Mazzci letter printed in America.

Marriage of Maria Jefferson to John Waylies Eppes.

X Y Z Message.

Passage of the Alien Bill.

Passage of the Sedition Bill.

Draft of the Kentucky Resolutions.

Kentucky Legislature arlopts resolutions.

Refuses Virginia Resolutions of Madison.

Drafts plan for the University of Va.

Prepares Parliamentary Mlanual.

Republican Caucus nominates Jefferson and Burr.

Removal of the capital to Washington. Offers Secretaryship of Navy to Livingston.

Election of Jefferson as President.

Offers Scerctaryship of War to Dearborn.

Offers French Mission to Livingston. 
1801.-Feb. 28.

Narch 4 .

5 .

9.

I 8.

May 11.

I5.

July I 5 .

Nov. 28.

1803.-Jan. II.

I8.

April.

I I .

May 2.

July.

24.

Oct. 20 .

1304.-Jan. 8.

Feb. Is.

April 17.

May 26.

Nov.

19.

I 805.-March 2.

August.

Dec. 20.

I806.-Feb. 24.

28.

April I9.

Oct. 25 .

Nov. 8.

I $807 .-$ Jan. 28.

31.
Farewell speech to Senate.

Inauguration of Jefferson as President.

Nominates Madison, Dearborn, and Lincoln to Cabinet.

Cabinet remits fines under Sedition Law.

Offers Paine passage on public vessel.

Appoints Gallatin Secretary of Treasury.

Cabinet discusses Barbary War.

Squadron ordered to Mediterranean.

Appoints Robert Smith Secretary of Navy.

Appoints Granger Postmaster-General.

Nominates Monroe Joint Minister to France.

Sends secret message on Lewis and Clark Expedition.

Prepares estimate of Christ.

Talleyrand offers to sell Louisiana.

Louisiana treaty signed at Paris.

Frames Louisiana Amendment to the Constitution.

Appoints Monroe Minister to Creat Britain.

Louisiana treaty ratified by Senate.

Offers Nonroe Governorship of Louisiana.

Approves act organizing Louisiana and Orleans.

Death of daughter Mary.

Appoints Munroe Minister to Spain.

Reèlected President of United States.

Nominates Bowdoin Minister to Spain.

Appoints Robert Smith Attorney-General.

Appoints Jacob Crowninshield Secretary of Navy.

Inaugurated as President.

Prepares Note on Conduct I 780-I.

Suggests alliance vitli Creat Pritain.

Nominates John Brechemidge Attoney-General

Ajds Barlow to Draft Bill for a National $\mathrm{T}_{11}$ : versity.

Nominated Bowdoin and Armstrong Joint Commissioners to Spain.

Writes letter to Alexander of Russia.

Nominates Monroe and Pinkney Joint Commissiuners.

Cabinet lecision on Burr.

Orlers to Willinson, in re Burr.

Sends additional message to Burr.

Sends message on Cumberland Road. 
I 807.-Feb. 22.

Feb. 28.

March 2.

30.

June 22.

Sept. I.

I I.

Nov. II.

Dec. 22.

1308.-Jan. 23.

Feb. 19.

29.

April 19.

1809.-Jan. 17.

March 1 .

4.

I 8 II.-Jan.

I812.-April I2. Dec. 17.

1813.-July.

1814.-Sept. 2 I.

Nuv. 21.

I8I 5.-Jan.

I 816.-July Io. Oct. I6.

1818.-Sept. I.

I822.- Nity.

1825.-Dee.

1826. - March io. July 4.
Calsinet Council on British negotiations.

Writes to King of Holland.

Sends Bill to End Slave Trade.

Beginning of trial of Burr.

Capture of the Chesapeake.

Proposes to seize the Floridas.

Acquittal of Burr.

Great Britain extends Orders in Council.

Signs Embargo Act.

Refuses to recommend Fast Day.

Sends message on Cumberland Road.

Sends reply to New York Society of St. Tammany.

Issues Proclamation on Embargo.

Furced to borrow money.

Sends repeal of Embargo.

Sends reply to citizens of Washington.

Close of Presidential term.

Issues circular letter on Public Appointments.

Urges seizures of the Floridas.

Sends Wirt his recollections of Patrick Henry.

Writes sketch of Meriwether Lewis.

Sells Mazzei's property in Richmond and borrows purchase money.

Offers Library to Congress.

Resigns presidency of American Philosophical Society.

Congress passes Bill to Purchase Library.

Completes schenc for the University of Va.

Writes sketch of Peyton Randolph.

Writes inscription for National Capitol.

Writes Anecdotes of Franklin.

Writes answer to "A Native of Virginia."

Drafts Protest for Virginia.

Executes will.

Death of Jefferson. 


AUTOBIOGRAPHY

YOL. $x,-1$ 



\section{THE WRITINGS}

\section{$\mathrm{OF}$ \\ THOMAS JEFFERSON}

\section{AUTOBIOGRAPHY}

\section{$1743^{-1} 79^{\circ}$}

I8z1. Jan. 6.

At the age of 77 , I begin to make some memoranda and state some recollections of dates \& facts concerning myself, for my own more ready reference $\&$ for the information of my family.

The tradition in my father's family was that their ancestor came to this country from Wales, and from near the mountain of Snowdon, the highest in Gr. Br. I notcd once a case from Wales in the law reports where a person of our name was either pl. or def. and one of the same name was Secretary to the Virginia company. 'Thesc are the only instances in which I have met with the name in that country. I have found it in our early records, but the first particular information I have of any ancestor was

${ }^{1}$ No Jefferson was ever secretary of the Virginia Company, but John Jefferson was a member of the company. He came to Virginia in the Bona Nova, in I6 19. 
my grandfather who lived at the place in Chesterfield called Ozborne's and ownd. the lands afterwards the glebe of the parish.' He had three sons, Thomas who died young, Field who settled on the waters of Roanolie and left numerous descendants, and Peter my father, who settled on the lands I still own called Shadwell ${ }^{2}$ adjoining my present residence. He was born Feb. 29, 1707/8, and intermarried I 739, with Jane Randolph, of the age of 19 . daur of Isham Randolph one of the seven sons of that name \& family settled at Dungeoness in (roochld. They trace their proligree far hack in England \& Scotland, to which let cvery one ascribe the faith \& merit he chooses.

My father's education had been quite neglected; but being of a strong mind, sound judgment and cager after information, he read much and improved himself insomuch that he was chosen with Joshua Fry, professor of Mathem. in W. \& M. college to continue the boundary line between Virginia \& $N$. Caroline which had been begun by Colo Byrd, and was afterwards employed with the same Mr. Fry to make the ist map of Virginia ${ }^{3}$ which had ever been marle, that of Capt Smith being merely a conjectural sketch. They possessed excellent materials for so much of the country as is below the blue ridge; little being then known beyond that ridge. He was the

This was (aph. Thomas fefferson, son of Thomas and Mary (Brancli) Jefferson, of Henrien ('o. He married Mary Ficld.

2 In Allemarle County. The house lot of too acres was purchased from William Randolph by "Henry Weatherhourne's biggest bow 1 of arrack punch."

3 Engraved and printed on four sheets in London, in 1751 , by 'Tlomas Jeffreys. The name Shadwell which it contains is even then one of the most western of settlements. 
$3 \mathrm{~d}$ or $4^{\text {th }}$ settler of the part of the country in which I live, which was about I737. He died Aug. I7. I 757 , leaving my mother a widow who lived till i 776 , with 6 daurs \& 2. sons, myself the elder. ${ }^{\text {' To my }}$ younger brother he left his estate on James river. called Snowden after the supposed birth-place of the family. To myself the lands, on which I was born \& live. He placed me at the English school at 5. years of age and at the Latin at 9 . where I continued until his death. My teacher Mr. Douglas ${ }^{2}$ a clergyman from Scotland was but a superficial Latinist, less instructed in Greek, but with the rudiments of these languages he taught me French, and on the death of my father I went to the revd. Mr. Maury ${ }^{3}$ a correct classical scholar, with whom I continued two years, and then went to $\mathrm{Wm}$. and Mary college, to wit in the spring of 1760 , where I continued 2. years. It was my great good fortune, and what probably fixed

I In Colonel Peter Jefferson's Prayer Book in the handwriting of Thomas Jefferson, are the following entries:

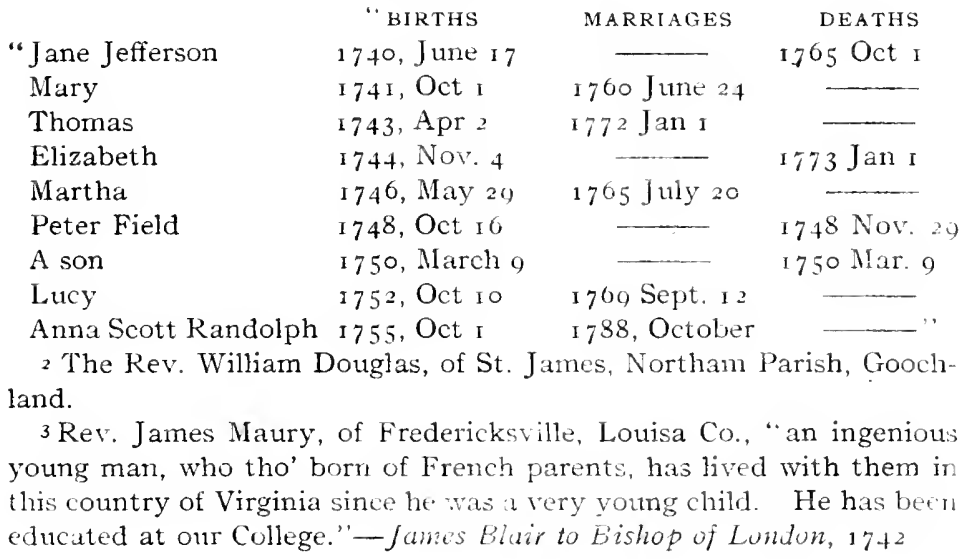


the destinies of my life that Dr. Wm. Small of Scotland was then professor of Mathematics, a man profound in most of the useful branches of science, with a happy talent of communication correct and gentlemanly manners, \& an enlarged \& liberal-mind. He, most happily for me, became soon attached to me \& made me his daily companion when not engaged in the school; and from his conversation I got my first views of the expansion of science \& of the system of things in which we are placed. Fortunately the Philosophical chair became vacant soon after my arrival at college, and he was appointed to fill it per interim: and he was the first who ever gave in that college regular lectures in Ethics, Rhetoric \& Belles lettres. He returned to Europe in 1762 , having previously filled up the measure of his goodness to me, by procuring for me, from his most intimate friend G. Wythe, a reception as a student of law, under his direction, and introduced me to the acquaintance and familiar table of Governor Fauquier, the ablest man who had ever filled that office. With him, and at his table, Dr. Small \& Mr. Wythe, his anici omnium horarum, \& myself, formed a partie quarree, \& to the habitual conversations on these occasions I owed much instruction. Mr. Wythe continuted to be my faithful and beloved Mentor in youth, and my most affectionate friend through life. In 1767 , he led me into the practice of the law at the bar of the General court, at which I continued until the revolution shut up the courts of justice. [For a sketch of the life \& character of Mr. Wythe see my letter of Aug. 3I. 20. to Mr. John Saunderson] 
In 1769 , I became a member of the legislature by the choice of the county in which I live, \& continued in that until it was closed by the revolution. I made one effort in that body for the permission of the emancipation of slaves, ${ }^{\prime}$ which was rejected: and indeed, during the regal government, nothing liberal could expect success. Our minds were circumscribed within narrow limits by an habitual belief that it was our duty to be subordinate to the mother country in all matters of government, to direct all our labors in subservience to her interests, and even to observe a bigoted intolerance for all religions but hers. The difficulties with our representatives were of habit and despair, not of reflection \& conviction. Experience soon proved that they could bring their minds to rights on the first summons of their attention. But the king's council, which acted as another house of legislature, held their places at will \& were in most humble obedience to that will: the Governor too, who had a negative on our laws held by the same tenure, \& with still greater devotedness to it: and last of all the Royal negative closed the last door to every hope of amelioration.

On the ist of January, I 772 I was married to - Martha Skelton wiclow of Bathurst Skelton, \& daughter of John Wayles, then 23. years old. Mr. Wayles was a lawyer of much practice, to which he

I Under the act of ad George II., no slave was to be set "free upon anv pretence whatsoever, except for some meritorious services, to be adjudged and allowed by the rovernor and Conncil." - Acts of the iscemhly, I760. No trace of this "effort" is recorded in the Journal of the House of Burgesses. 


\section{The Writings of}

was introduced more by his great industry, punctuality \& practical readiness, than to eminence in the science of his profession. He was a most agreeable companion, full of pleasantry \& good humor, and welcomed in every society. He acquired a handsome fortune, died in May, I773, leaving three daughters, and the portion which came on that event to Mrs. Jefferson, after the debts should be paid, which were very considerable, was about equal to my own patrimony, and consequently doubled the ease of our circumstances.

When the famous Resolutions of 1765 , against the Stamp-act, were proposed, I was yet a student of law in Wning. I attended the debate however at the door of the lobby of the H. of Burgesses, \& heard the splendid display of Mr. Henry's talents as a popular orator. They were great inkeed; such as I have never heard from any other man. He appeared to me to speak as Homer wrote. Mr. Johnson, a lawyer $\&$ member from the Northern Neck, seconded the resolns, \& by him the learning $\&$ the logic of the case were chiefly maintained. My recollections of these transactions may be seen pa. 6o, Wirt's life of P. H.,' to whom I furnished them.

In May, I 769, a meeting of the General Assembly was called by the Govr., La. Botetourt. I had then become a member; and to that meeting became known the joint resolutions $\&$ address of the Lords $\&$ Commons of $1768-9$, on the proceedings in Massachusetts. Counter-resolutions, $\&$ an address to the

\footnotetext{
1 Patrick Henry. Cf. post, sketch of Pitrick Henry, under i 814 . $\therefore$.llay sth.
} 
King, by the $\mathrm{H}$. of Burgesses were agreed to with little opposition, \& a spirit manifestly displayed of considering the cause of Massachusetts as a common one. The Governor dissolved us ' : but we met the next day in the Apollo ${ }^{2}$ of the Raleigh tavern, formed ourselves into a voluntary convention, drew up articles of association against the use of any merchandise imported from Gr. Britain, signed and recommended them to the people, repaired to our several connties, \& were re elected without any other exception than of the very few who had declined assent to our proceedings.

Nothing of particular excitement occurring for a considerable tine onr countrymen seemed to fall into a state of insensibility to our situation. The duty on tea not yet repealed \& the Declaratory act of a right in the British parl to bind us by their laws in all cases whatsocver, still suspended over us. But a court of inquiry held in $\mathrm{R}$. Island in 1762 , with a power to send persons to England to be tried for offences committed here ${ }^{3}$ was considered at our session of the spring of 1773 . as demanding attention. Not thinking our old \& leading members up to the point of forwardness \& zeal which the times required, Mr. Henry, R. H. Lee, Francis L. Lee, Mr. Carr \& myself agreed to meet in the evening in a private room of the Raleigh to consult on the state of things. There may have been a member or two nore wliom I

I May 16 th.

2 A public room sometimes called the "long room" in the tavern. There is a picture of it in The Century Magazine for November, 1875 .

3 This was the famous "Gaspee" inquiry, the date being a slip for 1772 . 
do not recollect. We werc all scnsible that the most urgent of all measures was that of coming to an understanding with all the other colonies to consider the British claims as a common cause to all, \& to produce an unity of action: and for this purpose that a commee of correspondec in cach colony would be the best instrument for intercommunication: and that their first measure would probably be to propose a meeting of deputies from every colony at some central place, who should be charged with the direction of the measures which should be taken by all. We therefore drew up the resolutions which may be seen in Wirt pa 87 . The consulting members proposed to me to move them, but I urged that it should be done by Mr. Carr, ${ }^{1}$ my friend \& brother in law, then a new nember to whom I wished an opportunity should be given of making known to the house his great worth \& talents. It was so agreed; he moved them, they were agreed to nem. con. and a commee of correspondence appointed of whom Peyton Randolph, the Speaker, was chairman. The Govr. (then Ld. Dunmore) dissolved us, but the commee met the next day, prepared a circular letter to the Speakers of the other colonies, inclosing to each a copy of the resolns and left it in charge with their chairman to forward them by expresses.

The origination of these commees of correspondence between the colonies has been since claimed for Massachusetts, and Marshall II. I5 I, has given into this error, altho' the very note of his appendix to which he refers, shows that their establmt was con-

I Dabney Carr. He married Martha Jefferson. 
fined to their own towns. This matter will be seen clearly stated in a letter of Samuel Adams Wells to me of Apr. 2, i8 89, and my answer of May i2. I was corrected by the letter of Mr. Wells in the information I had given $\mathrm{Mr}$. Wirt, as stated in his note, pa. 87 , that the messengers of Massach. \& Virga crossed each other on the way bearing similar propositions, for Mr. Wells shows that Mass. did not adopt the measure but on the receipt of our proposn delivered at their next session. Their message therefore which passed ours, must have related to something else, for I well remember P. Randolph's informing me of the crossing of our messengers.

The next event which excited our sympathies for Massachusets was the Boston port bill, by which that port was to be shut up on the rst of June, r 774 . This arrived while we were in session in the spring of that year. The lead in the house on these subjects being no longer left to the old members, Mr. Henry, R. H. Lee, Fr. L. Lee, 3. or 4. other members, whom I do not recollect, and myself, agreeing that we must boldly take an unequivocal stand in the line with Massachusetts, determined to meet and consult on the proper measures in the council chaniber, for the benefit of the library in that room. We were under conviction of the necessity of arousing our people from the lethargy into which they had fallen as to passing events; and thought that the appointment of a day of general fasting \& prayer would be most likely to call up \& alarm their attention.' ${ }^{\prime}$ No

I "Mr. Jefferson and Charles Lee may be said to have originated a fast to electrify the people from the pulpit.

Those gentlemen, 
example of such a solemnity had existed since the days of our distresses in the war of 55 . since which a new generation had grown up. With the help therefore of Rushworth, whom we rummaged over for the revolutionary precedents \& forms of the Puritans of that day, preserved by him, we cooked up a resolution, somewhat modernizing their phrases, for appointing the ist day of June, on which the Port bill was to commence, for a day of fasting, humiliation \& prayer, to implore heaven to avert from us the evils of civil war, to inspire us with firmness in support of our rights, and to turn the hearts of the King \& parliament to moderation \& justice.' To give greater emphasis to our proposition, we agreed to wait the next morning on Mr. Nicholas, ${ }^{2}$ whose grave \& religious character was more in unison with the tone of our resolution and to solicit him to move it. We accordingly went to him in the morning. He moved it the same day; the ist of Jume was proposed and it passed without opposition. ${ }^{3}$ The Governor dis-

knowing that Robert Carter Nicholas, the chairman of the committee of religion, was no less zealous than themselves against the attempt to starve thousands of American people into a subservience to the ministry, easily persuaded him to put forth the strength of his character, on an occasion which he thought to be pious, and move a fast, to be observed on the first lay of Junc. - Edmund Randolph's (MS.) History of Virginia, p. 24 .

'Printed in Force's Archives, the 1, 350.

2 Robert Carter Nicholas.

" It (the fist) was spoke of by some as a Schem calculated to inflame and excite an enthusiastic zeal in the Minds of the People under a (Coat of Religion, than which nothing could be more calumnious and uniust . . The Resolution was not Smuggled, but proposed in a very full House, not above one Dissentient appearing amongst near an humlred members." - R. ('. Nicholas' Considerations on the Present Situte of l'irginia Examined, P. 40. 
solved us as usual. We retired to the Apollo as before, agreed to an association, ${ }^{\prime}$ and instructed the commee of correspdce to propose to the corresponding commees of the other colonies to appoint deputies to meet in Congress at such place, annually, as should be convenient to direct, from time to time, the measures required by the general interest: and we declared that an attack on any one colony should be considered as an attack on the whole. This was in May. ${ }^{2}$ We further recommended to the several counties to elect deputies to meet at Wmsbg the ist of Aug ensuing, to consider the state of the colony, \& particularly to appoint delegates to a general Congress, should that measure be acceded to by the commees of correspdce generally. ${ }^{3}$ It was acceded to, Philadelphia was appointed for the place, and the 5 th of Sep. for the time of meeting. We returned home, and in our several counties invited the clergy to meet assemblies of the people on the Ist of June, ${ }^{4}$ to perform the ceremonies of the day, \& to address to them discourses suited to the occasion. The people met generally, with anxiety \& alarm in their conntenances, and the effect of the day thro' the whole colony was like a shock of electricity, arousing every man \& placing him erect \& solidly on his centre.

'Printed in Rind's Virginia Gazettc for May 26, 1774. It was signeel by eighty-nine members.

2 May 27, 1774.

3 This was"in a separate resolution, adopter Nay joth, by "all the members that were then in town." It was not to "elect deputies " but merely a reference of the consideration of important papers to such "late members of the Honse of Burgesses" who should then gather.

4 By the original invitation, printed herein under June, 1774 , it will be seen that the call was for June $23 \mathrm{~d}$, instead of the 1 st. 
They chose universally delegates for the convention. Being elected one for my own county I prepared a draught of instructions to be given to the delegates whom we should send to the Congress, and which I meant to propose at our meeting. In this I took the ground which, from the beginning I had thought the only one orthodox or tenable, which was that the relation between $\mathrm{Gr}$. Br. and these colonies was exactly the same as that of England \& Scotland after the accession of James \& until the Union, and the same as her present relations with Hanover, having the same Executive chief but no other necessary political connection; and that our cmigration from England to this country gave her no more rights over us, than the emigrations of the Danes and Saxons gave to the present authorities of the mother country over England. In this doctrine however I had never been able to get any one to agree with me but Mr. Wythe. He concurred in it from the first dawn of the question What was the political relation between us \& England? Our other patriots Randolph, the Lees, Nicholas, Pendleton stopped at the half-way house of John Dickinson who admitted that England had a right to regulate our commerce, and to lay duties on it for the purposes of regulation, but not of raising revenue. But for this ground there was no foundation in compact, in any acknowledged principles of colonization, nor in reason: expatriation being a natural right, and acted on as such, by all nations, in all ages. I set out for Wmsbg some days before that appointed for our meeting, but was taken ill of a dysentery on the road, \& unable to pro- 
ceed. I sent on therefore to Wmsbg two copies of my draught, the one under cover to Peyton Randolph, who I knew would be in the chair of the convention, the other to Patrick Henry. Whether Mr. Henry disapproved the ground taken, or was too lazy to read it (for he was the laziest man in reading I ever knew) I never learned: but he communicated it to nobody. Peyton Randolph informed the convention he had received such a paper from a member prevented by sickness from offering it, in his place, and he laid it on the table for perusal. It was read generally by the members, approved by many, but thought too bold for the present state of things; but they printed it in pamphlet form under the title of A Summary view of the rights of British America. It found its way to England, was taken up by the opposition, interpolated a little by $\mathrm{Mr}$. Burke so as to make it answer opposition purposes, and in that

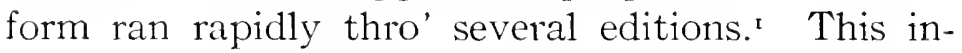
formation I had from Parson Hurt, ${ }^{2}$ who happened at the time to be in London, whither he had gone to receive clerical orders. And I was informed afterwards by Peyton Randolph that it had procured me the honor of having my name inserted in a long list of proscriptions enrolled in a bill of attainder commenced in one of the houses of parliament, but suppressed in embryo by the hasty step of events which warned them to be a little cautious. ${ }^{3}$ Montague,

I There are several errors in this statement, which are treated in the note on the pamphlet. See post, I 774 .

2 Rev. John Hurt.

3 It is hardly necessary to state that this so-called bill was a myth, which had no basis in fact. But at the time when these leaders were 
agent of the $\mathrm{H}$. of Burgesses in England made extracts from the bill, copied the names, and sent them to Peyton Randolph. The names I think were about 2o which he repeated to me, but I recollect those only of Hancock, the two Adamses, Peyton Randolph himself, Patrick Henry, \& myself. ${ }^{1}$ The convention met on the ist of Aug, renewed their association, appointed delegates to the Congress, gave them instructions very temperately \& properly expressed, both as to style \& matter; and they repaired to Philadelphia at the time appointed. The splendid proceedings of that Congress at their ist session belong to general history, are known to every one, and need not therefore be noted here. They terminated their session on the 26 th of ()ctob, to meet again s on the roth May ensuing. The convention at their enstuing session of Mar, ' $75,^{2}$ approved of the proceedings of Congress, thanked their delegates and reappointed the same persons to represent the colony at . the meeting to be held in May: and foreseeing the probability that Peyton Randolph their president and Speaker also of the $\mathrm{H}$. of $\mathrm{B}$. might be called off, they added me, in that event to the relegation.

$\mathrm{Mr}$. Randolph was according to expectation obliged to leave the chair of Congress to attend the Gen. Assembly summoned by Ld. Dunmore to meet on the ist day of Jume 1775. Ld. North's conciliatory

risking such a proseription, it was the current belief, both in England and America, that steps would be taken against them, and it is not strange that, in the absence of the proof to the contrary which we now possess, it was belicred in.

'See Cirardin's History of Virginia, Appendix No. 12, note.-T.J.

2 Murch 27,1775 . See Force's Archives, the II, 172. 
propositions, as they were called, had been received by the Governor and furnished the subject for which this assembly was convened. Mr. Randolph accordingly attended, and the tenor of these propositions being generally known, as having been addressed to all the governors, he was anxious that the answer of our assembly, likely to be the first, ${ }^{2}$ should harmonize with what he knew to be the sentiments and wishes of the body he had recently left. He feared that Mr. Nicholas, whose mind was not yet up to the mark of the times, would undertake the answer, \& therefore pressed me to prepare an answer. ' did so, and with his aid carried it through the house ith long and doubtful scruples from Mr. Nicholas nd James Mercer, and a dash of cold water on it .ere $\&$ there, enfeebling it somewhat, but finally vith unanimity or a vote approaching it." This eing passed, I repaired immediately to Philadelphia, nd conveyed to Congress the first notice they had of it. It was entirely approved there. I took my seat with them on the 2 Ist of June. On the 24 th, a commee which had been appointed to prepare a declaration of the causes of taking up arms, brought in cheir report (drawn I believe by J. Rutledge) which not being liked they recommitted it on the 26 th, and added Mr. Dickinson and myself to the committee. On the rising of the house, the commee having not yet met, I happened to find myself near Govr W. Livingston, and proposed to him to draw the paper.

It had already been referred to the Congress by New Jersey, May roth, 1775 .

See post, under June $12,1775$. Yoi. $1,-2$. 
He excused himself and proposed that I should draw it. On my pressing him with urgency, "we are as yet but new acquaintances, sir, said he, why are you so earnest for my doing it?" "Because, said I, I have been informed that you drew the Address to the people of Gr. Britain, a production certainly of the finest pen in America." "On that, says he, perhaps sir you may not have been correctly informed." I had received the information in Virginia from Colo Harrison on his return from that Congress. Lee, Livingston \& Jay had been the commee for that draught. The first, prepared by Lee, had been disapproved \& recommitted. The second was drawn by Jay, but being presented by Govr Livingston, had led Colo Harrison into the error. The next morning, walking in the hall of Congress, many members being assembled but the house not yet formed, I observed Mr. Jay, speaking to R. H. Lee, and leading him by the button of his coat, to me. "I understand, sir, said he to me, that this gentleman informed you that Gorr Livingston drew the Address to the people of Gr Britain." I assured him at once that I had not received that information from $\mathrm{Mr}$. Lee $\&$ that not a word had ever passed on the subject hetween Mr. Lee \& myself; and after some explanations the subject was dropt. These gentlemen had hat some sparrings in debate before, and continued ever very hostile to each other.

I prepared a draught of the Declaration committed to us. ${ }^{1}$ It was too strong for Mr. Dickinson. He still retained the hope of reconciliation with the ${ }^{1} C f$. note on Jefferson's draft, post, under July 6, 1775 . 
mother country, and was unwilling it should be lessened by offensive statements. He was so honest a man, $\&$ so able a one that he was greatly indulged even by those who could not feel his scruples. We therefore requested him to take the paper, and put it into a form he could approve. He did so, preparing an entire new statement, and preserving of the former only the last 4. paragraphs \& half of the preceding one. We approved \& reported it to Congress, who accepted it. Congress gave a signal proof of their indulgence to Mr. Dickinson, and of their great desire not to go too fast for any respectable part of our body, in permitting him to draw their second petition to the king according to his own ideas, ' and passing it with scarcely any amendment. The disgust against this humility was general; and Mr. Dickinson's delight at its passage was the only circumstance which reconciled them to it. The vote being passed, altho' further observn on it was out of order, he could not refrain from rising and expressing his satisfaction and concluded by saying "there is but one word, Mr. President, in the paper which I disapprove, \& that is the word Congress," on which Ben Harrison rose and said "there is but one word in the paper, Mr. President, of which I approve, and that is the word Congress."

On the 22 d of July Dr. Franklin, Mr. Adams, R. H. Lee, \& myself, were appointed a commee to consider and report on Ld. North's conciliatory resolution. The answer of the Virginia assembly on that subject having been approved I was requested by

I "Scarcely I believe altering one" struck out in MS. by author. 
the commec to prepare this report, which will account for the similarity of feature in the two instruments.'

()n the 5 th of May, 1776 , the convention of Virrinia instructed their delegates in Congress to pro. pose to that body to declare the colonies independent of ( $r$. Britain, and appointed a commee to prepare a declaration of rights and plan of government.?

${ }^{3}$ In Congress, Friday June 7. i 776 . The delegates from Virginia moved ${ }^{4}$ in obedience to instructions from their constituents that the Congress should declare that these United colonies are \& of right ought to be free \& independent states, that they are absolved from all allcgiance to the British crown, and that all political connection between them \& the state of Great Britain is \& ought to be, totally dissolved; that measures should be immediately taken for procuring the assistance of foreign powers, and a conferleration be formed to bind the colonies more closely together. 5

1 See post, muler fuly $31,1775$.

2 Printed in Foree's Archives, 5 th, vi, for.

3Here, in the original manuscript, commence the "two preceding sheets" referred to ly Mr. Jefferson, as containing "notes" taken hy lim "whilst these things were going on." They are easily distinguishod from the hody of the MS. in which they were inserted by him, heing of a fatper very different in size, quality, and color from that on which the lateris witten.

4 Introduced by Richard Henry Lee. His antograph resolution is reproduced in Etting's Momorials of $1776.1 \% .4$.

5."The Congress sat till 7 o'elock this evening in consequence of a molion of R. II. Lee's remelering ourselves iree and independent States. The sensible part of the Ilouse opposed the Motion-they had no oljection to forming a Scheme of a Treaty which they would send to France by proper Persous \& uniting this Continent by a Confederacy: they saw no wisdom in a Declaration of ludependence, nor any other 
The house being obliged to attend at that time to some other business, the proposition was referred to the next day, when the members were ordered to attend punctually at ten o'clock.

Saturday June 8 . They proceeded to take it into consideration and referred it to a committee of the whole, into which they immediately resolved themselves, and passed that day \& Monday the roth in debating on the subject.

It was argued by Wilson, Robert R. Livingston, E. Rutledge, Dickinson and others

'That tho' they were friends to the measures themselves, and saw the impossibility that we should ever again be united with Gr. Britain, yet they were against adopting them at this time:

That the conduct we had formerly observed was wise \& proper now, of deferring to take any capital step till the voice of the people drove us into it:

That they were our power, \& without them our declarations could not be carried into effect;

That the people of the middle colonies (Maryland, Delaware, Pennsylva, the Jerseys \& N. York) were

Purpose to be enforced by it, but placing ourselves in the power of those with whom we mean to treat, giving our Enemy Notice of our Intentions before we had taken any steps to execute them. The event, however, was that the Question was postponed; it is to be renewed on Monday when I mean to move that it should be postponed for 3 Weeks or Months. In the mean Time the plan of Confederation $\mathbb{E}$ the Scheme of Treaty may go on. I don't know whether I shall succeed in this Motion; I think not, it is at least doubtful. However I must do what is right in my own Eyes, \& Consequences must take Care of thernselves. I wish you had been here-the whole Argument was sustained on one side by R. Livingston, Wilson, Dickenson, \& myself, \& by the Power of all N. England, Virginia \& Georgia at the other."-E. Rutledge to John Jay, fune 9,1776 . 
not yet ripe for bidding adieu to British connection, but that they were fast ripening $\&$ in a short time would join in the general voice of America:

That the resolution entered into by this house on the $5^{5}$ th of May ${ }^{1}$ for suppressing the exercise of all powers derived from the crown, had shown, by the ferment into which it had thrown these middle colonies, that they had not yet accommodated their minds to a separation from the mother country:

That some of them had expressly forbidden their delegates to consent to such a declaration, and others had given no instructions, \& consequently no powers to give such consent:

That if the delegates of any particular colony had no power to declare such colony independant, certain they were the others could not declare it for them: the colonies being as yet perfectly independant of each other:

That the assembly of Pennsylvania was now sitting above stairs, their convention would sit within a few days, the convention of New York was now sitting, \& those of the Jerseys \& Delaware counties would meet on the Monday following, \& it was probable these bodies would talse up the question of Independance \& would declare to their delegates the voice of their state:

I That "every kind of authority under the saicl crown should be tolislly suppressed" and "to aldopt such governument ats shall . . . lest conduce to the happiness and safety of their constituents."Journal of Congress, 11., 166, 17. . Duane, in a letter to Jay, dated May roth, states that: "it has oceasioned a great alarm here PPhiladelphial, and the cautious folks are very fearful of its being attended with many ill conse"quences." 
That if such a declaration should now be agreed to, these delegates must retire \& possibly their colonies might secede from the Union:

That such a secession would weaken us more than could be compensated by any foreign alliance:

That in the event of such a division, foreign powers would either refuse to join themselves to our fortunes, or, having us so much in their power as that desperate declaration would place us, they would insist on terms proportionably more hard and prejudicial:

That we had little reason to expect an alliance with those to whom alone as yet we had cast our eyes:

That France \& Spain had reason to be jealous of that rising power which would one day certainly strip them of all their American possessions:

That it was more likely they should form a connection with the British court, who, if they should find themselves unable otherwise to extricate themselves from their difficulties, would agree to a partition of our territories, restoring Canada to France, $\&$ the Floridas to Spain, to accomplish for themselves a recovery of these colonies:

That it would not be long before we should receive certain information of the disposition of the French court, from the agent whom we had sent to Paris for that purpose:

That if this disposition should be favorable, by waiting the event of the present campaign, which we all hoped would be successful, we should have reason to expect an alliance on better terms:

That this would in fact work no delay of any affectual aid from such ally, as, from the advance of 
the season \& distance of our situation, it was impossible we could receive any assistance during this campaign:

That it was prudent to fix among ourselves the terms on which we should form alliance, before we declared we would form one at all events:

And that if these were agreed on, \& our Declaration of Independance ready by the time our Ambassador should be prepared to sail, it would be as well as to go into that Declaration at this day.

On the other side it was urged by J. Adams, Lee, Wythe, and others

That no gentleman had argued against the policy or the right of separation from Britain, nor had supposed it possible we should ever renew our connection; that they had only opposed its being now declared:

That the question was not whether, by a declaration of independance, we should make ourselves what we are not; but whether we should declare a fact which already exists:

That as to the people or parliament of England, we had ahwais been independent of them, their restraints on our trade deriving efficacy from our acruiesecnce only, \& not from any rights they possesser of imposing them, \& that so far our connection had been federal only \& was now dissolved by the commencement of hostilities:

That as to the King, we had been bound to him by allegiance, but that this bond was now dissolved by his assent to the late act of parliament, by which he declares us out of his protection, and by his levying 
war on us, a fact which had long ago proved us out of his protection; it being a certain position in law that allegiance \& protection are reciprocal, the one ceasing when the other is withdrawn:

That James the IId. never declared the people of England out of his protection yet his actions proved it \& the parlianent declared it:

No delegates then can be denied, or ever want, a power of declaring an existing truth:

That the delegates from the Delaware counties having declared their constituents ready to join, there are only two colonies Pennsylvania \& Maryland whose delegates are absolutely tied up, and that these had by their instructions only reserved a right of confirming or rejecting the measure:

That the instructions from Pennsylvania might be accounted for from the times in which they were drawn, near a twelvemonth ago, since which the face of affairs has totally changed:

That within that time it had become apparent that Britain was determined to accept nothing less than a carte-blanche, and that the King's answer to the Lord Mayor Aldernen \& common council of London, which had come to hand four days ago, must have satisfied every one of this point:

'That the people wait for us to lead the way:

That thcy are in favour of the measure, tho' the instructions given by some of their represcntatives are not:

That the voice of the representatives is not always consonant with the voice of the people, and that this is remarkably the case in these middle colonies: 
That the effect of the resolution of the 15 th of May has proved this, which, raising the murmurs of some in the colonies of Pennsylvania \& Maryland, called forth the opposing voice of the freer part of the people, \& proved them to be the majority, even in these colonies:

That the backivardness of these two colonies might be ascribed partly to the influence of proprietary power \& connections, \& partly to their having not yet been attacked by the enemy:

That these causes were not likely to be soon removed, as there seemed no probability that the cnemy would make either of these the seat of this summer's war:

That it would be vain to wait either weeks or months for perfect unanimity, since it was impossible that all men should ever become of one sentiment on any question:

That the conduct of some colonies from the beginning of this contest, had given rcason to suspect it was their settled policy to keep in the rear of the confederacy, that their particular prospect might be letter, cren in the worst event:

That therefore it was necessary for those colonies who had thrown themselves forward \& hazarded all from the beginning, to come forward now also, and put all again to their own hazard:

That the history of the Dutch revolution, of whom three states only confederated at first proved that a sccession of some colonies would not be so dangerous as some apprehended:

That a declaration of Independence alone could 
render it consistent with European delicacy for European powers to treat with us, or even to receive an Ambassador from us:

That till this they would not receive our vessels into their ports, nor acknowledge the adjudications of our courts of admiralty to be legitimate, in cases of capture of British vessels:

That though France \& Spain may be jealous of our rising power, they must think it will be much more formidable with the addition of Great Britain; and will therefore see it their interest to prevent a coalition; but should they refuse, we shall be but where we are; whereas without trying we shall never know whether they will aid us or not:

That the present campaign may be unsuccessful, \& therefore we had better propose an alliance while our affairs wear a hopeful aspect:

That to await the event of this campaign will certainly work delay, because during this summer France may assist us effectually by cutting off those supplies of provisions from England \& Ireland on which the enemy's armies here are to depend; or by setting in motion the great power they have collected in the West Indies, \& calling our enemy to the defence of the possessions they have there:

That it would be idle to lose time in settling the terms of alliance, till we had first determined we would enter into alliance:

That it is necessary to lose no time in opening a trade for our people, who will want clothes, and will want money too for the paiment of taxes:

And that the only misfortune is that we did not 
enter into alliance with France six months sooner, as besides opening their ports for the vent of our last year's produce, they might have marched an army into Germany and prevented the petty princes there from selling their unhappy subjects to subdue us.

It appearing in the course of these debates that the colonies of N. York, New Jersey, Pennsylvania, Delaware, Maryland, and South Carolina ${ }^{\text {I }}$ were not yet matured for falling from the parent stem, but that they were fast advancing to that state, it was thought most prudent to wait a while for them, and to postpone the final decision to July I . but that this might occasion as little delay as possible a committee was appointed ${ }^{2}$ to prepare a declaration of independence. The commee were J. Adams, Dr. Franklin, Roger Sherman, Robert R. Livingston \& myself. Committees were also appointed at the same time to prepare a plan of confederation for the colonies, and to state the terms proper to be proposed for foreign alliance. The committee for drawing the declaration of Independence desired me to do it. It was accordingly done, and being approved by them, I reported it to the house on Friday the 28 th of June when it was read and ordered to lie on the table. ${ }^{3}$ On

1 "Had not yet advanced to" struck out in MS. by author.

${ }^{2}$ June 10,1776 .

3 A different account is given of this by John Adams, as follows:

"The committee had several meetings, in which were proposed the articles of which the declaration was to consist, and minutes made of them. The committee then appointed Mr. Jefferson and me to draw them up in form, and clothe them in a proper dress. The sub-committee met, and considered the minutes, making such observations on them as then occurred, when $\mathrm{Mr}$. Jefferson desired me to take them to my lodgings, and make the draught. This I declined, and gave several 


\section{Monday, the ist of July the house resolved itself into} a commee of the whole $\&$ resumed the consideration of the original motion made by the delegates of

reasons for declining. 1. That he was a Virginian, and I a Massaclusettensian. 2. That he was a southern man, and 1 a northern one. 3. That $I$ had been so obnoxious for my early and constant zeal in promoting the measure, that any dratught of mine would undergo a more scvere serutiny and criticism in Congress, than one of his composition. 4. And lastly, and that would be reason enough if there were no other, I had a great opinion of the elegance of his pen, and nonc at all of ny ow1. I therefore insisted that no hesitation should be made on his part. He accordingly took the minutes, and in a day or two produced to me his draught. Whether I made or suggested any correction, I remember not. The report was made to the committce of five, by them examined, but, whether altered or corrected in any thing, I cannot recollect. But, in substanee at least, it was reported to Congress, where, after a severe criticism, and striking out several of the most oratorical paragraphs, it was adopted on the fourth of July, 1776 . and published to the world."-A utobiograplty of John Adams.

"You inquire why so young a man as Mr. Jefferson was placed at the head of the Committee for preparing a Declaration of Independence? I answer: it was the Frankfort advice, to place Virginia at the head of every thing. Mr. Riehard Henry Lee might be gone to Virgina, to his sick family, for aught I know, but that was not the reason of Mr. Jefferson's appointment. There were three committees appointed at the same time. One for the Declaration of Independence, another for preparing the articles of Confederation, another for preparing a treaty to be proposed to France. Mr. Lee was chosen for the committec of Confederation, and it was not thought convenient that the same person should be upon both. Mr. Jefferson eame into Congress, in June, I 775, and brought with him a reputation for literature, science, and a happy talent of composition. Writings of his were handed about, remarkable for the peculiar felicity of expression. Though a silent member in Congress, he was so prompt, frank, explicit, and decisive upon committees and in conversation, not even Samuel Adams was more so, that he soon seized upon my heart and upon this oceasion I gave him my vote, and did all in my power to procure the votes of others. I think he had one more vote than any other, and that placed him at the head of the committec. I had the next highest number, and that placed me the seeond. The committee met, discussed the subjeet, and then appointed Mr. Jefferson and me to make the draft, I suppose because we were the two first on the list.

"The sub-committee met. Jefferson proposed to me to make the 


\section{Virginia, which being again debated through the day, was carried in the affirmative by the votes of N. Hampshire, Connecticut, Massachusetts, Rhode Island, N. Jersey, Maryland, Virginia, N. Carolina, \&}

draft. I said: 'I will not.' 'You should do it.' 'Oh! no.' 'Why will you not? You ought to do it." 'I will not.' 'Why?' 'Reasons enough.' 'What can be your reasons?' 'Reason first-You are a Virginian, and a Virginian ought to appear at the head of this business. Reason second-I am obnoxious, suspected, and unpopular. You are very much otherwise. Reason third-You can write ten times better than I can.' 'Well,' said Jefferson, 'If you are decided, I will do as well as I canl.' 'Very well. When you have drawn it up, we will have a meeting.'

"A ineeting we accordingly had, and conned the paper over. I was delighterl with its high tone and the flights of oratory with which it abounded, especially that concerning negro slavery, which, though I knew his Southern brethren would never suffer to pass in Congress, I certainly never would oppose. There were other expressions which I would not have inserted, if I had drawn it 1 p, particularly that which called the King tyrant. I thought this too personal; for I never believed George to be a tyrant in disposition and in nature: I always believed him to be deceived by his courtiers on both sides of the Atlantic, and in his official capacity only, cruel. I thought the expression too passionate, and too much like scolding, for so grave and solemn a document; but as Franklin and Sherman were to inspect it afterwards, I thought it would not becone me to strike it out. I consented to report it, and do not now remember that I made or suggested a single alteration.

"We reported it to the committee of five. It was read, and I do not remember that Franklin or Sherman criticised any thing. We were all in luaste. Congress was impatient, and the instrument was reported, as I helieve, in Jefferson's handwriting, as he first drew it. Congress cut off about a quarter of it, as I expected they would; but they obliterated some of the best of it, and left all that was exceptionable, if anything in it was. I have long wondered that the original draught has not been published. I suppose the reason is, the vehement philippic against negro slavery."-John Adams to Timothy Pickcring, Aug. 22, I822.

To this Jefferson replied:

"You have doubtless seen Timothy Pickering's fourth of July observations on the Declaration of Independence. If his principles and prejudices, personal and political, gave us no reason to doubt whether 


\section{Georgia. S. Carolina and Pennsylvania voted against} it. Delaware having but two members present, they were divided. ${ }^{\mathrm{r}}$ The delegates for New York de-

he had truly quoted the information he alleges to have received from Mr. Adams, I should then say, that in some of the particulars, Mr. Adams' memory has led him into unquestionable error. At the age of eighty-eight, and forty-seven years after the transactions of Independence, this is not wonderful. Nor should I, at the age of eighty, on the small advantage of that difference only, venture to oppose my memory to his, were it not supported by written notes, taken by myself at the moment and on the spot. He says 'the committee of five, to wit, Doctor Franklin, Sherman, Livingston and ourselves, met, discussed the subject, and then appointed him and myself to make the draught; that we, as a sub-committee, met, and after the urgencies of each on the other, I consented to undertake the task, that the draught being made, we, the sub-committee, met, and conned the paper over, and he does not remember that he made or suggested a single alteration.' Now these details are quite incorrect. The committee of five met; no such thing as a sub-committee was proposed, but they unanimously pressed on myself alone to undertake the draught. I consented; I drew it; but before I reported it to the committee, I communicated it separately to Doctor Franklin and Mr. Adams, requesting their corrections because they were the two members of whose judgments and amendments I wished most to have the benefit, before presenting it to the committee: and you have seen the original paper now in my hands, with the corrections of Doctor Franklin and Mr. Adans interlined in their own handwritings. Their alterations were two or three only, and merely verbal. I then wrote a fair copy, reported it to the committee, and from them unaltered, to Congress. This personal communication and consultation with Mr. Adams, he has misremembered into the actings of a sub-committee. Pickering's observations, and Mr. Adams' in addition, 'that it contained no new ideas, that it is a common place compilation, its sentiments hacknied in Congress for two years before, and its essence contained in Otis' pamphlet,' may all be true. Of that I am not to be the judge. Richard Henry Lee charged it as copied from Locke's treatise on government. Otis' pamphlet I never saw, and whether I had gathered my ideas from reading or reflection $I$ do not know. I know only that 1 turned to neither book nor pamphlet while writing it. I did not consider it as any part of my charge to invent new ideas altogether, and to offer no sentiment which hal ever heen expressed before." - Letter to J. Madison, Aug. 30, 1823.

I George Read (opposing) and Thomas McKean. 
clared they were for it themselves \& were assured their constituents were for it, but that their instructions having been drawn near a twelvemonth before, when reconciliation was still the general object, they were enjoined by them to do nothing which should impede that object. They therefore thought themselves not justifiable in voting on either side, and asked leave to withdraw from the question, which was given them. The commee rose \& reported their resolution to the house. Mr. Edward Rutledge of S. Carolina then requested the determination might be put off to the next day, as he believed his colleagues, tho' they disapproved of the resolution, would then join in it for the sake of unanimity. The ultimate question whether the house would agree to the resolution of the committee was accordingly postponed to the next day, when it was again moved and S. Carolina concurred in voting for it. In the meantime a

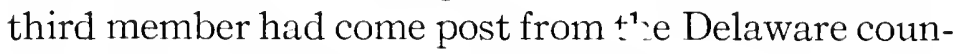
ties ' and turned the vote of that colony in favour of the resolution. Members ${ }^{2}$ of a different sentiment attending that morning from Pennsylvania also, their vote was changed, so that the whole I 2 colonies who were authorized to vote at all, gave their voices for it; and within a few days, ${ }^{3}$ the convention of $\mathrm{N}$. York approved of it and thus supplied the void occasioned by the withdrawing of her delegates from the vote.

Congress proceeded the same day ${ }^{4}$ to consider the

I Casar Rodney.

${ }^{2}$ Dickinson and Robert Morris did not attend, Wilson changed his vote, and with Franklin and Morton, outvoted Willing and Humphreys.

3 July 9 th.

4 Monday, July ist. No sitting was held on Saturday. 
declaration of Independance which had been reported $\&$ lain on the table the Friday preceding, and on Monday referred to a commee of the whole. The pusillanimous idea that we had friends in England worth keeping terms with, still haunted the minds of many. For this reason those passages which conveyed censures on the people of England were struck out, lest they should give them offence. The clause too, reprobating the enslaving the inhabitants of Africa, was struck out in complaisance to South Carolina and Georgia, who had never attempted to restrain the importation of slaves, and who on the contrary still wished to continue it. Our northern brethren also I believe felt a little tender under those censures; for tho' their people have very few slaves themselves yet they had been pretty considerable carriers of them to others. The debates having taken up the greater parts of the $2 \mathrm{~d} 3 \mathrm{~d} \& 4$ th days of July were, ${ }^{\mathrm{I}}$ in the evening of the last, closed the declaration was reported by the commee, agreed to by the house and signed by every member present except Mr. Dickinson. ${ }^{2}$ As the sentiments of men are known not only by what they receive, but what they

IThe "Resolution" for independence was under discussion on the Ist of July. The declaration on July $2 \mathrm{~d}, 3 \mathrm{~d}$, and $4^{\text {th. }}$.

2 The question whether the declaration was signed on the $4^{\text {th }}$ of July, as well as on the $2 \mathrm{~d}$ of August, has been a much vexed one, but a careful study of it must make almost certain that it was not. The MS. Journal of Congress (that printed by order of Congress being fabricated and altered) merely required its "authentication," which we know from other cases was by the signatures of the president and secretary; who accordingly signed it "by order and in behalf of the Congress," and the printed copies at once sent out had only these signatures. "It is also certain that several of the inembers then in Convii. 1, - 3 , 
reject also, I will state the form of the declaration as originally reported. The parts struck out by Congress shall be distinguished by a black line drawn under them; \& those inserted by them shall be placed in the margin or in a concurrent column. ${ }^{\mathrm{r}}$

gress would have refused to sign it on that day, and that the Congress therefore had good cause to postpone the signing till certain of the delegations should receive new instructions, or be changed; and also till its first effect on the people might be seen. For these reasons the declaration was not even entered in the journal, though a blank was left for it, and when it was inserted at a later period, the list of signers was taken from the engrossed copy, though had there been one signed on the $4^{\text {th }}$ of July it would certainly have been the one printed from, as including the men who were in Congress on that day and who voted on the question, instead of one signed by a number of men who were neither present nor members when the declaration was adopted. Moreover, though the printed journal afterwards led John Adams to believe and state that the declaration was signed on the $4^{\text {th }}$, we have his contemporary statement, on July gth, that "as soon as an American seal is prepared, I conjecture the Declaration will be subscribed by all the members." And we have the positive denial of McKean that "no person signed it on that day," and this statement is substantiated by the later action of Congress in specially permitting him to sign what he certainly would have already done on the 4 th, had there been the opportunity. Opposed to these direct statements and probabilities, we have Jefferson's positive statement, three times repeated, that such a signing took place, but as he follows his nearly contemporary one with the statements that it was "signed. by every member present except Mr. Dickinson," when we have proof positive that all the New York delegates refused to even rote, much less sign, and that Dickinson was not even present in Congress on that day, it is evident that this narrative is not wholly trustworthy.

1 "I expected you had in the Preamble to our form of Government, exhausted the subject of complaint agt Geo. $3 \mathrm{~d} \&$ was at a loss to discover what Congress would do for one to their Declaration of Independence without copying, but find you have acquitted your selves very well on that score."-E. Pendletom to Jefferson, July 22.

"I am also obliged by ye Original Declaration of Independence, which I find your brethren have treated as they did ye Manifesto last suminer-altered it much for the worse; their hopes of a Reconciliation might restrain them from plain truths then, but what could cramp them now?"-E. Pendleton to Jefferson, Ang. IO, I776. 
A DEClaRATION BY THE REPRESENTATIVES OF THE UNITED STATES OF AMERICA, IN GENERAL CONGRESS ASSEMBLED

When in the course of human events it becomes necessary for one people to dissolve the political bands which have connected them with another, and to assume anlong the powers of the earth the separate \& equal station to which the laws of nature and of nature's God entitle them, a decent respect to the opinions of mankind requires that they should declare the causes which impel them to the separation.

We hold these truths to be self-erident: that all men are created equal; that they are endowed by their creator with inherent and inalienable certain rights; that among these are life, liberty,

$\&$ the pursuit of happiness: that to secure these rights, governments are instituted among men, deriving their just powers from the consent of the governed; that whenever any form of government becomes destructive of these ends, it is the right of the people to alter or abolish it, \& to institute new government, laying it's foundation on such principles, \& organizing it's powers in such form, as to them shall seem most likely to effect their safety $\&$ happiness. Prudence indeed will dictate that governments long established should not be changed for light \& transient causes; and accordingly all experience hath shown that mankind are more disposed to suffer while evils are sufferable, than to right themselves by abolishing the forms to which they are 
accustomed. But when a long train of abuses \& usurpations begun at a distinguished period and pursuing invariably the same object, evinces a design to reduce them under absolute despotism, it is their right, it is their duty to throw off such government, \& to provide new guards for their future security. Such has been the patient sufferance of these colonies; \& such is now the necessity which conalter strains them to expunge their former systems of government. The history of the present king of Great Britain is a history of unrepeated remitting injuries \& usurpations, among which appears no solitary fact to contradict the all having uniform tenor of the rest but all have in direct object the establishment of an absolute tyranny over these states. To prove this let facts be submitted to a candid world for the truth of which we pledge a faith yet unsullied by falsehood.

He has refused his assent to laws the most wholesome \& necessary for the public good.

He has forbidden his governors to pass laws of immediate \& pressing importance, unless suspended in their operation till his assent should be obtained; \& when so suspended, he has utterly neglected to attend to them.

He has refused to pass other laws for the accommodation of large districts of people, unless those people would relinquish the right of representation in the legislature, a right inestimable to them, \& formidable to tyrants only.

He has called together legislative bodies at places unusual, uncomfortable, and distant from the deposi- 
tory of their public records, for the sole purpose of fatiguing them into compliance with his measures.

He has dissolved representative houses repeatedly \& continually for opposing with manly firmness his invasions on the rights of the people.

He has refused for a long time after such dissolutions to cause others to be elected, whereby the legislative powers, incapable of annihilation, have returned to the people at large for their exercise, the state remaining in the meantime exposed to all the dangers of invasion from without $\&$ convulsions within.

He has endeavored to prevent the population of these states; for that purpose obstructing the laws for naturalization of foreigners, refusing to pass others to encourage their migrations hither, \& raising the conditions of new appropriations of lands.

$\mathrm{He}$ has suffered the administration of obstructed justice totally to cease in some of these

by states refusing his assent to laws for establishing judiciary powers.

He has made our judges dependant on his will alone, for the tenure of their offices, $\&$ the amount $\&$ paiment of their salaries.

He has erected a multitude of new offices by a self assumed power and sent hither swarms of new officers to harass our people and eat out their substance.

He has kept among us in times of peace standing armies and ships of war without the consent of our legislatures.

He has affected to render the military independant of, \& superior to the civil power. 
He has combined with others to subject us to a jurisdiction foreign to our constitutions \& unacknowledged by our laws, giving his assent to their acts of pretended legislation for quartering large bodies of armed troops among , ...; for protecting them by a mock-trial from punishment for any murders which they should commit on the inhabitants of these states; for cutting off uur trade with all parts of the world; for imposing taxes on us without in many our consent; for depriving us [ ] of the cases benefits of trial by jury for transporting us beyond seas to $\mathrm{b} \approx$ tried for pretend $\mathrm{d}$ offences; for abolishing the free system of English laws in a neighboring province, establishing therein an arbitrary government, and eniargins, it's houndaries, so as to render it at once an exmple and fit instrument for introducing the same absolute colunies rule into these states; for taking away our charters, abolishing our most valuable laws, and altering fundamentally the forms of iur governments; for suspending our own legislatures, \& declaring themselves invested with power to legislate for us in all cases whatsoever.

by declaring: us vut of his protection. and wagith war dpainst 11 s.

He has abdicated government here withdrawing his governors, and declaring us out of his allegiance \& protection.

He has plundered our seas, ravaged our coasts, burnt our towns, \& destroyed the lives of our jeople.

$H e$ is at this time transporting large armies of foreign merenaries to compleat the works of death, lesolation \& tyranny already begun with circum- 
stances of cruelty and perfidy [ ] unworthy the head of a civilized nation.

He has constrained our fellow citizens taken captive on the high seas to bear arms scarcely the most barbarous ages, \& totally against their country, to become the executioners of their friends \& brethren, or to fall themselves by their hands.

$\mathrm{H} \odot$ has [ ] endeavored to bring on the inhabitants of our frontiers the merciless Indian savages, whose known rule of war-

domested domestic in. surrection among us, $\&$ has fare is an undistinguished destruction of all ages, sexes, \& conditions of existence.

He has incited treasonable insurrections of our fellow-citizens, with the allurements of forfeiture $\&$ confiscation of our property.

He has waged cruel war against himan nature itself, violating it's most sacred rights of life and liberty in the persons of a distant people who never offended him, captivating \& carrying them into slavery in another hemisphere, or to incur miserable death in their transportation thither. This piratical warfare, the opprobium of INJFIDEL powers, is the warfare of the CHRISTIAN king of Great Britain. Determined to keep open a market wher MEN should be bought \& sold, he has prostituted his negative for suppressing every legislative attempt to prohibit or to restrain this execrable commerce. And that this assemblag of horrors might want no fact of distinguished die, ho is now exciting those very people to rise in arms among us, and to purchase that liberty of which he has deprived them, by murdering the people on whom ha also obtruded them: thus paying 
off former crimes committed against the LIBERTIES of one people, with crimes which he urges them to commit against the LIVES of another.

In every stage of these oppressions we have petitioned for redress in the most humble terms: our repeated petitions have been answered only by repeated injuries.

A prince whose character is thus marked by every act which may define a tyrant is unfit to be the ruler frec of a [] people who mean to be free. Future ages will scarcely believe that the hardiness of one man adventured, within the short compass of twelve years only, to lay a foundation so broad \& so undisguised for tyranny over a people fostered \& fixed in principles of freedom.

Nor have we been wanting in attention to our British brethren. We have warned them from time $\underset{\text { rantable }}{\text { an unwar- }}$ to time of attempts by their legislature to us extend a jurisdiction over these our states. We have reminded them of the circumstances of our emigration \& settlement here, no one of which could warrant so strange a pretension: that these were effected at the expense of our own blood \& treasure, unassisted by the wealth or the strength of Great Britain: that in constituting indeed our several forms of government, we had adopted one common king, thereby laying a foundation for perpetual league \& amity with them: but that submission to their parliament was no part of our constitution, nor ever in have

and we have conjured them by id a, if history may be credited: and, we [ ] appealed to their native justice and magnanimity as well as to the ties of our common 
kindred to disavow these usurpations which were likely to interrupt our connection and correspondence. They too have been deaf to

the voice of justice \& of consanguinity, and when occasions have been given them, by the regular course of their laws, of removing from their councils the disturbers of our harmony, they have, by their free election, re-established them in power. At this very time too they are permitting their chief magistrate to send over not only soldiers of our common blood, but Scotch \& foreign mercenaries to invade $\&$ destroy us. These facts have given the last stab to agonizing affection, and manly spirit bids us to renounce forever these unfeeling brethren. We must endeavor to forget our former love for them, and hold them as we hold the rest of mankind, enemies in war, in peace friends. We might have been a free and a great people together; but a communication of grandeur \& of freedom it scems is below their dignity. Be it so, since they will have it. The road to happiness \& to glory is open to us too. We will tread it apart from them, and ac- we must thereforc quiesce in the necessity which de- and hold them as nuonces our eternal separation [ ] !

We therefore the representatives of the United States of America in General Congress assembled do in the name \& by authority of the good people of these states reject \&
We therefore the representatives of the United States of America in General Congress assembled, appealing to the supreme judge of the world for the rectitude of our inten- 
renounce all allegiance \& subjection to the kings of Great Britain \& all others who may hereafter claim by, through or under them: we utterly dissolve all political connection which may heretofore have subsisted between us \& the people or parliament of Great Britain: \& finally we do assert \& declare these colonies to be free \& independent states, \& that as free \& independent states, they have full power to levy war, conclude peace, contract alliances, establish commerce, \& to do all other acts \& things which independent states may of right do.

And for the support of this declaration we mutually pledge to each other our lives, our fortunes, \& our sacred honor. tions, do in the name, $\&$ by the authority of the good people of these colonies, solemnly publish \& declare that these united colonies are \& of right ought to be free $\&$ independent states; that they are absolved from all allegiance to the British crown, and that all political connection between them \& the state of Great Britain is, \& ought to be, totally dissolved; \& that as free \& independent states they have full power to levy war, conclude peace, contract alliances, establish commerce $\&$ to do all other acts $\&$ things which independant states may of right do.

And for the support of this declaration, with a firm reliance on the protection of divine providence we mutually pledge to each other our lives, our fortunes, \& our sacred honor. ${ }^{\mathrm{I}}$

This is printed just as Jefforson prepared it for the press. By 
The Declaration thus signed on the 4 th, on paper was engrossed on parchment, \& signed again on the 2d. of August. ${ }^{\prime}$

On Friday July i2. the Committee appointed to draw the articles of confederation reported them, and on the $22 \mathrm{~d}$. the house resolved themselves into a committee to take them into consideration. On the 3 oth. \& 3 Ist. of that month \& ist. of the ensuing, those articles were debated which determined the proportion or quota of money which each state should furnish to the common treasury, and the manner of voting in Congress. The first of these articles was expressed in the original draught in these words." "Art. XI. All charges of war \& all

comparing it with the text as printed post, under July 4,1776 , it will be seen that he took the liberty of somewhat changing and even expunging portions.

I This is an interlineation made at a later period-apparently after the question as to the signing of the declaration was raised. Jefferson has also written the following on a slip and pasted it on the sheet:

"Some erroneous statements of the proceedings on the declaration of independence having got before the public in latter times, Mr. Samuel A. Wells asked explanations of me, which are given in my letter to him of May I2. I 9 . before and now again referred to. I took notes in my place while these things were going on, and at their close wrote them out in form and with correctness and from $i$ to 7 of the two preceding sheets are the originals then written; as the two following are of the earlier debates on the Confederation, which I took in like manner."

${ }^{2}$ In the H'orks of John Adams (ii., 492) are printed his memoranda of the debates on the confederation, wherein he has recorded the following sentences from Jefferson's speeches on that subject: Article 14. "The limits of the Southern Colonies are fixed. Mores an amendment, that all purchases of lands, not within the boundaries of any Colony, shall be made by Congress of the Indians in a great Council." Article 15. "What are reasonable limits? What security have we, that the Congress will not curtail the present settlements of the States? 
other expenses that shall be incurred for the common defence, or general welfare, and allowed by the United States assembled, shall be defrayed out of a common treasury, which shall be supplied by the several colonies in proportion to the number of inhabitants of every age, sex \& quality, except Indians not paying taxes, in each colony, a true account of which, distinguishing the white inhabitants, shall be triennially taken \& transmitted to the Assembly of the United States."

Mr. [Samuel] Chase moved that the quotas should be fixed, not by the number of inhabitants of every condition, but by that of the "white inhabitants." He admitted that taxation should be alwais in proportion to property, that this was in theory the true rule, but that from a variety of difficulties, it was a rule which could never be adopted in practice. The value of the property in every State could never be estimated justly \& equally. Some other measure for the wealth of the State must therefore be devised, some standard referred to which would be more simple. He considered the number of inhabitants as a tolerably good criterion of property, and that this might alwais be obtained. He therefore thought it the best mode which we could adopt, with one exception only. He observed that negroes are prop-

I have no doubt that the colonies will limit themselves." Article I6. "Thinks the Congress will have a short meeting in the Fall and another in the Spring." Article 17. "Explains it to mean the Indians who live in the Colony. These are subject to the laws in some degree.

I protest against the right of Congress to decide upon the right of Virginia. Virginia has released all claims to lands settled by Maryland, \&c." 
erty, and as such cannot be distinguished from the lands or personalities held in those States where there are few slaves, that the surplus of profit which a Northern farmer is able to lay by, he invests in cattle, horses, \&c. whereas a Southern farmer lays out that same surplus in slaves. There is no more reason therefore for taxing the Southern states on the farmer's head, \& on his slave's head, than the Northern ones on their farmer's heads \& the heads of their cattle, that the method proposed would therefore tax the Southern states according to their numbers \& their wealth conjunctly, while the Northern would be taxed on numbers only: that negroes in fact should not be considered as members of the state more than cattle \& that they have no more interest in it.

Mr. John Adams observed that the numbers of people were taken by this article as an index of the wealth of the state, \& not as subjects of taxation, that as to this matter it was of no consequence by what name you called your people, whether by that of freemen or of slaves. That in some countries the labouring poor were called freemen, in others they were called slaves; but that the difference as to the state was imaginary only. What matters it whether a landlord employing ten labourers in his farm, gives them annually as much money as will buy them the necessaries of life, or gives them those necessaries at short hand. The ten labourers add as much wealth annually to the state increase it's exports as much in the one case as the other. Certainly 500 freemen produce no more profits, no greater surplus for the 
paiment of taxes than 500 slaves. Therefore the state in which are the labourers called freemen should be taxed no more than that in which are those called slaves. Suppose by any extraordinary operation of nature or of law one half the labourers of a state could in the course of one night be transformed into slares: would the state be made the poorer or the less able to pay taxes? That the condition of the laboring poor in most countries, that of the fishermen particularly of the Northern states, is as abject as that of slaves. It is the number of labourers which produce the surplus for taxation, and numbers therefore indiscriminate1y, are the fair index of wealth. That it is the use of the word "property" here, \& it's application to some of the people of the state, which produces the fallacy. How does the Southern farmer procure slaves? Either by importation or by purchase from his neighbor. If he imports a slave, he adds one to the number of labourers in his country, and proportionably to it's profits \& abilities to pay taxes. If he buys from his neighbor it is only a transfer of a labourer from one farm to another, which does not change the annual produce of the state, \& therefore should not change it's tax. That if a Northern farmer works ten labourers on his farm. he can, it is true, invest the surplus of ten men's labour in cattle: but so may the Southern farmer working ten slaves. That a state of one hundred thousand freemen can maintain no more cattle than one of one hundred thousand slaves. Therefore they have no more of that kind of property. That a slave may indeed from the custom of 
speech be more properly called the wealth of his master, than the free labourer might be called the wealth of his employer: 'but as to the state, both were equally it's wealth, and should therefore equally add to the quota of it's tax.

$\mathrm{Mr}$. [Benjamin] Harrison proposed as a compromise, that two slaves should be counted as one freeman. He affirmed that slaves did not do so much work as freemen, and doubted if two effected more than one. That this was proved by the price of labor. The hire of a labourer in the Southern colonies being from 8 to $£$ I 2. while in the Northern it was generally $£ 24$.

Mr. [James] Wilson said that if this amendment should take place the Southern colonies would have all the benefit of slaves, whilst the Northern ones would bear the burthen. That slaves increase the profits of a state, which the Southern states mean to take to themselves; that they also increase the burthen of defence, which would of course fall so much the heavier on the Northern. That slaves occupy the places of freemen and eat their food. Dismiss your slaves $\&$ freemen will take their places. It is our duty to lay every discouragement on the importation of slaves; but this amendment would give the jus trium liberorun to him who would import slaves. That other kinds of property were pretty equally distributed thro' all the colonies: there were as many cattle, horses, \& sheep, in the North as the South, \& South as the North; but not so as to slaves. That experience has shown that those colonies have been alwais able to pay most which have the most inhabitants, whether they be 
black or white, and the practice of the Southern colonies has alwais been to make every farmer pay poll taxes upon all his labourers whether they be black or white. He acknowledges indeed that freemen work the most; but they consume the most also. They do not produce a greater surplus for taxation. The slave is neither fed nor clothed so expensively as a freeman. Again white women are exempted from labor generally, but negro women are not. In this then the Southern states have an advantage as the article now stands. It has sometimes been said that slavery is necessary because the commodities they raise would be too dear for market if cultivated by freemen; but now it is said that the labor of the slave is the dearest.

Mr. Payne ${ }^{\mathrm{u}}$ urged the original resolution of Congress, to proportion the quotas of the states to the number of souls.

Dr. [John] Witherspoon was of opinion that the value of lands \& houses was the best estimate of the wealth of a nation, and that it was practicable to obtain such a valuation. This is the true barometer of wealth. The one now proposed is imperfect in itself, and unequal between the States. It has been objected that negroes eat the food of freemen \& therefore should be taxed. Horses also eat the food of freemen; therefore they also should be taxed. It has been said too that in carrying slaves into the estimate of the taxes the state is to pay, we do no more than those states themselves do, who alwais take slaves into the estimate of the taxes the individual is to pay. But

I Robert Treat Paine. 
the cases are not parallel. In the Southern colonies slaves pervade the whole colony; but they do not pervade the whole continent. That as to the original resolution of Congress to proportion the quotas according to the souls, it was temporary only, \& related to the monies heretofore emitted: whereas we are now entering into a new compact, and therefore stand on original ground.

Aug. I. The question being put the amendment proposed was rejected by the votes of N. Hampshire, Massachusetts, Rhode island, Connecticut, N. York, N. Jersey, \& Pennsylvania, against those of Delaware, Maryland, Virginia, North \& South Carolina. Georgia was divided.

The other article was in these words. "Art. XVII. In determining questions each colony shall have one vote."

July 30. 31. Aug. I. Present 4I. members. Mr. Chase observed that this article was the most likely to divide us of any one proposed in the draught then under consideration. That the larger colonies had threatened they would not confederate at all if their weight in congress should not be equal to the numbers of people they added to the confederacy; while the smaller ones declared against a union if they did not retain an equal vote for the protection of their rights. That it was of the utmost consequence to bring the parties together, as should we sever from - each other, either no foreign power will ally with us at all, or the different states will form different alliances, and thus increase the horrors of those scenes of civil war and bloodshed which in such a state of vol. $1 .-4$. 
separation $\&$ independance would render us a miserable people. That our importance, our interests, our peace required that we should confederate, and that mutual sacrifices should be made to effect a compromise of this difficult question. He was of opinion the sr.taller colonies would lose their rights, if they were not in some instances allowed an equal vote; and therefore that a discrimination should take place among the questions which would come before Congress. ${ }^{\mathrm{T}}$ That the smaller states should be secured in all questions concerning life or liberty $\&$ the greater ones in all respecting property. He therefore proposed that in votes relating to money, the voice of each colony should be proportioned to the number of its inhabitants.

Dr. Franklin " thought that the votes should be so proportioned in all cases. He took notice that the Delaware counties had bound up their Delegates to disagree to this article. He thought it a very extraordinary language to be held by any state, that they would not confederate with us unless we would let them dispose of our money. Certainly if we vote equally we ought to pay equally; but the smaller states will hardly purchase the privilege at this price. That had he lived in a state where the representation, originally equal, had become unequal by time $\&$ accident he might have submitted rather than disturb government; but that we should be very wrong to set out in this practice when it is in our power to establish what is right. That at the time of the

I "He therefore proposed" struck out in MS. by author.

a "Seconded the proposition" struck out in MS. by author. 
Union between England and Scotland the latter ha!l made the objection which the smaller states now do. But experience had proved that no unfairness had ever been shown them. That their advocates had prognosticated that it would again happen as in times of old, that the whale would swallow Jonas, but he thought the prediction reversed in event and that Jonas had swallowed the whale, for the Scotch had in fact got possession of the government and gave laws to the English. He reprobated the original agreement of Congress to vote by colonies and therefore was for their voting in all cases according to the number of taxables.'

Dr. Witherspoon opposed cvery alteration of the article. All men admit that a confederacy is necessary. Should the idea get abroad that there is likely to be no union among us, it will damp the minds of the people, diminish the glory of our struggle, \& lessen it's importance; because it will open to our view future prospects of war $\&$ dissension among ourselves. If an equal vote be refused, the smaller states will become vassals to the larger; \& all experience has shown that the vassals $\&$ subjects of free states are the most enslaved. He instanced the Helots of Sparta \& the provinces of Rome. He observed that foreign powers discovering this blemish would make it a handle for disengaging the smaller states from so unequal a confederacy. That the colonies should in fact be considered as individuals; and that as such, in all disputes they should have an

1 "So far going beyond Mr. Chase's proposition," struck out in MS. by author. 
equal vote; that they are now collected as individuals making a bargain with each other, \& of course had a right to vote as individuals. That in the East India company they voted by persons, \& not by their proportion of stock. That the Belgic confederacy voted by provinces. That in questions of war the smaller states were as much interested as the larger, \& therefore should vote equally; and indeed that the larger states were more likely to bring war on the confederacy in proportion as their frontier was more extensive. He admitted that equality of representation was an excellent principle, but then it must be of things which are co-ordinate; that is, of things similar \& of the same nature: that nothing relating to individuals could ever come before Congress; nothing but what would respect colonies. He distinguished between an incorporating \& a federal union. The union of England was an incorporating one; yet Scotland had suffered by that union: for that it's inhabitants were drawn from it by the hopes of places \& employments. Nor was it an instance of equality of representation; because while Scotland was allowed nearly a thirteenth of representation they were to pay only one fortieth of the land tax. He expressed his hopes that in the present enlightened state of men's minds we might expect a lasting confederacy, if it was founded on fair principles.

John Adams advocated the voting in proportion to numbers. He said that we stand here as the representatives of the people. That in some states the people are many, in others they are few; that 
therefore their vote here should be proportioned to the numbers from whom it comes. Reason, justice, $\&$ equity never had weight enough on the face of the earth to govern the councils of men. It is interest alone which does it, and it is interest alone which can be trusted. That therefore the interests within doors should be the mathematical representatives of the interests without doors. That the individuality of the colonies is a mere sound. Does the individuality of a colony increase it's wealth or numbers. If it does, pay equally. If it does not add weight in the scale of the confederacy, it cannot add to their rights, nor weigh in argument. A. has £50. B. £500. C. $f_{1000}$. in partnership. Is it just they should equally dispose of the monies of the partnership? It has been said we are independent individuals making a bargain together. The question is not what we are now, but what we ought to be when our bargain shall be made. The confederacy is to make us one individual only; it is to form us, like separate parcels of metal, into one common mass. We shall no longer retain our separate individuality, but become a single individual as to all questions submitted to the confederacy. Therefore all those reasons which prove the justice \& expediency of equal representation in other assemblies, hold good here. It has been objected that a proportional vote will endanger the smaller states. We answer that an equal vote will endanger the larger. Virginia, Pennsylvania, \& Massachusetts are the three greater colonies. Consider their distance, their difference of produce, of interests $\&$ of manners, $\&$ it is apparent they can 
never have an interest or inclination to combine for the oppression of the smaller. That the smaller will naturally divide on all questions with the larger. Rhode isld, from it's relation, similarity \& intercourse will generally pursue the same objects with Massachusetts; Jersey, Delaware \& Maryland, with Pennsylvania.

Dr. [Benjamin] Rush took notice that the decay of the liberties of the Dutch republic proceeded from three causes. I. The perfect unanimity requisite on all occasions. 2. Their obligation to consult their constituents. 3. Their voting by provinces. This last destroyed the equality of representation, and the liberties of great Britain also are sinking from the same defect. That a part of our rights is deposited in the hands of our legislatures. There it was admitted there should be an equality of representation. Another part of our rights is deposited in the hands of Congress: why is it not equally necessary there should be an equal representation there? Were it possible to collect the whole body of the people together, they would determine the questions submitted to them by their majority. Why should not the same majority decide when voting here by their representatives? The larger colonies are so providentially divided in situation as to render every fear of their combining visionary. Their interests are different, \& their circumstances dissimilar. It is more probable they will become rivals \& leave it in the power of the smaller states to give preponderance to any scale they please. The voting by the number of free inhabitants will have one excellent effect, that 
of inducing the colonies to discourage slavery \& to encourage the increase of their free inhabitants.

Mr. [Stephen] Hopkins observed there were 4 larger, 4 smaller, \& + middle-sized colonies. That the 4 largest would contain more than half the inhabitants of the confederated states, \& therefore would govern the others as they should please. That history affords no instance of such a thing as equal representation. The Germanic body votes by states. The Helvetic body does the same; \& so does the Belgic confederacy. That too little is known of the ancient confederations to say what was their practice.

Mr. Wilson thought that taxation should be in proportion to wealth, but that representation should accord with the number of freemen. That government is a collection or result of the wills of all. That if any government could speak the will of all, it would be perfect; and that so far as it departs from this it becomes imperfect. It has been said that Congress is a representation of states; not of individuals. I say that the objects of its care are all the individuals of the states. It is strange that annexing the name of "State" to ten thousand men, should grive them an equal right with forty thousand. This must be the effect of magic, not of reason. As to those matters which are referred to Congress, we are not so many states, we are one large state. We lay aside our individuality, whenever we come here. The Germanic body is a burlesque on government; and their practice on any point is a sufficient authority \& proof that it is wrong. The greatest 
imperfection in the constitution of the Belgic confederacy is their voting by provinces. The interest of the whole is constantly sacrificed to that of the small states. The history of the war in the reign of $Q$. Anne sufficiently proves this. It is asked shall nine colonies put it into the power of four to govern them as they please? I invert the question, and ask shall two millions of people put it in the power of one million to govern them as they please? It is pretended too that the smaller colonies will be in danger from the greater. Speak in honest language \& say the minority will be in danger from the majority. And is there an assembly on earth where this danger may not be equally pretended? The truth is that our proceedings will then be consentaneous with the interests of the majority, and so they ought to be. The probability is much greater that the larger states will disagree than that they will combine. I defy the wit of man to invent a possible case or to suggest any one thing on earth which shall be for the interests of Virginia, Pennsylvania \& Massachusetts, and which will not also be for the interest of the other states. ${ }^{\mathrm{x}}$

These articles reported July I 2. 76 were debated

I Here end the notes which Jefferson states were taken "while these things were going on, and at their close" were "written out in form and with correctness." Much of their value depends on the date of their writing, but there is nothing to show this, except negative evidence. The sheets were all written at the same time, which makes the writing after Aug. I, 1776 ; while the misstatements as to the signing, and as to Dickinson's presence, would seem almost impossible unless greater time even than this had elapsed between the occurrence and the notes. The MS. is, moreover, considerably corrected and interlined, which would hardly be the case if merely a transcript of rough notes. 
from day to day, \& time to time for two years, werc ratified July 9, ' 78 , by ro states, by $N$. Jersey on the 26th. of Nov. of the same year, and by Delaware on the $23 \mathrm{~d}$. of Feb. following. Maryland alone held off 2 years more, acceding to them Mar I, 8I. and thus closing the obligation.

Our delegation had been renewed for the ensuing year commencing Aug. I . but the new government was now organized, a meeting of the legislature was to be held in Oct. and I had been elected a member by my county. I knew that our legislation under the regal government had many very vicious points which urgently required reformation, and I thought I could be of more use in forwarding that work. I therefore retired from my seat in Congress on the $2 \mathrm{~d}$. of Sep. resigned it, and took my place in the legislature of my state, on the 7 th. of October.

On the i Ith.' I moved for leave to bring in a bill for the establishment of courts of justice, the organization of which was of importance; I drew the bill it was approved by the commee, reported and passed after going thro' it's due course. ${ }^{2}$

${ }^{1}$ Ordcred, That leave be given to bring in a bill For the cstablishment of courts of justice within this Commonwealth, and that Mr. Jefferson, Mr. Smith, Mr. Bullitt, Mr. Fleming, Mr. Watts, Mr. Williams, Mr. Gray. Mr. Bland, Mr. Braxton, and Mr. Curle do prepare and bring in the same.-Journal of the House of Delegates, 1776 , p. 12.

2 This, is crroneously stated. After the committee was formed they were directed by the House of Delegates to "divide the subject thereof into five distinct bills." Three of these. ("Appeals," "Chancery," and "Assize") were introduced by Jefferson Nov. 25, 1776, and the other two ("Admiralty" and "County") Dec. 4, 1776. All but the "Admiralty" (which was promptly passed) encountered bitter opposition, (see note to: Bill for suspending execution for debt, Dec. 6, 1776), and none were acted upon at this session, nor at the succeeding one. On 
On the r ath. I obtained leave to bring in a bill declaring tenants in tail to hold their lands in fee simple. ${ }^{1}$ In the earlier times of the colony when lands were to be obtained for little or nothing, some provident individuals procured large grants, and, desirous of founding great families for themselves, settled them on their descendants in fee-tail. The transmission of this property from generation to generation in the same name raised up a distinct set of families who, being privileged by law in the perpetuation of their wealth were thus formed into a Patrician order, distinguished by the splendor and luxury of their establishments. From this order too the king habitually selected his Counsellors of State, the hope of which distinction devoted the whole corps to the interests $\&$ will of the crown. To annul this privilege, and instead of an aristocracy of wealth, of more harm and danger, than benefit, to society, to make an opening for the aristocracy of virtue and talent, which nature has wisely provided for the direction of the interests of society, \& scattered with equal hand through all it's conditions, was deemed essential to a well ordered republic. To effect it no violence was necessary, no deprivation of natural right, but rather an enlargement of it by a repeal of the law. For this would authorize the present holder to divide the property among his

Oct. 30, 1777 , fresh leave was granted to introduce bills establishing Courts of Appeals, "General Court and Court of Assize" and Chancery. The latter two were passed at this session, and the first passed at the first session in 1778 . They are all printed in A Collection of the Public Acts of Virginia. Richmond, 1785, pp. $66,70,84$.

1 See post, Oct. I $2,1776$. 
children equally, as his affections were divided; and would place them, by natural generation on the level of their fellow citizens. But this repeal was strongly opposed by Mr. Pendleton, who was zealously attached to ancient establishments; and who, taken all in all, was the ablest man in debate I have ever met with. He had not indeed the poetical fancy of $\mathrm{Mr}$. Henry, his sublime imagination, his lofty and overwhelming diction; but he was cool, smooth and persuasive; his language flowing, chaste \& embellished, his conceptions quick, acute and full of resource; never vanquished; for if he lost the main battle, he returned upon you, and regained so much of it as to make it a drawn one, by dexterous manœuvres, skirmishes in detail, and the recovery of small advantages which, little singly, were important altogether. You never knew when you were clear of him, but were harassed by his perseverance until the patience was worn down of all who had less of it than himself. - Add to this that he was one of the most virtuous \& benevolent of men, the kindest friend, the most amiable \& pleasant of companions, which ensured a favorable reception to whatever came from him. Finding that the general principles of entails could not be maintained, he took his stand on an amendment which he proposed, instead of an absolute abolition, to permit the tenant in tail to convey in fee simple, if he chose it: and he was within a few votes of saving so much of the old law. But the bill passed finally for entire abolition.

In that one of the bills for organizing our judiciary system which proposed a court of chancery, I had 
provided for a trial by jury of all matters of fact in that as well as in the courts of law. He defeated it by the introduction of 4 . words only, "if either party chuse." I The consequence has been that as no suitor will say to his judge, "Sir, I distrust you, give me a jury" juries are rarely, I might say perhaps never seen in that court, but when called for by the Chancellor of his own accord.

The first establishment in Virginia which became permanent was made in 1607 . I have found no mention of negroes in the colony until about 1650 . The first brought here as slaves were by a Dutch ship; after which the English commenced the trade and continued it until the revolutionary war. That suspended, ipso facto, their further importation for the present, and the business of the war pressing constantly on the legislature, this subject was not acted on finally until the year 78 . when I brought in a bill to prevent their further importation. ${ }^{2}$ This

I This was one of the five bills into which the committee by order of the House of Delegates divided the law for the establishment of courts of justice (see Journal of the House of Delegates, p. 69). But the original draft of the bill (which is not in Jefferson's handwriting) in the Virginia State Archives contains only the clause concerning juries in the bill as passed, which was to the effect that by mutual agreement of the parties the case could be submitted to the judge, without the calling of a jury, but otherwise a jury trial should be given; such having been the law before the extinction of the courts by the revolutionary conflict. Moreover, with the rough draft of the bill already alluded to, is a separate paper, in Pendleton's handwriting, containing his amendments to the bill, which does not alter in any way the jury system in the original bill.

2 This is erroneously stated. The earliest step towards this limitation was the permission of the House of Delegates, Nov. 8, i 777 , to John Henry and Starke to introduce a bill "to prohibit the importation of slaves." On Nov. 22 d, Henry introduced a bill which was read 
passed without opposition, and stopped the increase of the evil by importation, leaving to future efforts its final eradication.

The first settlers of this colony were Englishmen, loyal subjects to their king and church, and the grant to Sr. Walter Raleigh contained an express Proviso that their laws "should not be against the true Christian faith, now professed in the church of England." As soon as the state of the colony admitted, it was divided into parishes, in each of which was established a minister of the Anglican church, endowed with a fixed salary, in tobacco, a glebe house and land with the other necessary appendages. To meet these expenses all the inhabitants of the parishes were assessed, whether they were or not, members of the established church. Towards Quakers who came here they were most cruelly intolerant, driving them from the colony by the severest penalties. In process of time however, other scctarisms were introduced, chiefly of the Presbyterian family; and the established clergy, secure for life in their glebes and salaries, adding to these generally the emoluments of a classical school, found employment

for a first and second time on that day, and then postponed from time to time till the end of the session. In the next session, the matter was taken up de novo, on Oct. I 5, i 778 , by the House of Delegates ordering the committee of trade to prepare a new bill. It was introduced by Kella as chairman of the committee on Oct. I 5 th, passed on Oct. 22 d, amended by the Senate on the $23 \mathrm{~d}$, and finally concurred in by the House, Oct. 27, I 778 . Jefferson thus clearly had nothing to do with the first bill, and, as he did not take his seat at the second session till Nov. 3 oth, it is equally certain he had nothing to do with the one which was adopted.--See Journal of the House of Delegates for 1777 , pp. 17 , 40: for 1778 , pp. 1 1 , 13, 19, 23. The original draft of the bill, now in the Virginia State Archives, is not in Jefferson's handwriting. 
cnough, in their farms and schoolrooms for the rest of the week, and devoted Sunday only to the edification of their flock, by service, and a sermon at their parish church. Their other pastoral functions were little attended to. Against this inactivity the zeal and industry of sectarian preachers had an open and undisputed field; and by the time of the revolution, a majority of the inhabitants had become dissenters from the established church, but were still obliged to pay contributions to support the Pastors of the minority. This unrighteous compulsion to maintain teachers of what they decmed religious errors was grievously felt during the regal government, and without a hope of relief. But the first republican legislature which met in 76. was crowded with petitions to abolish this spiritual tyranny. These brought on the severest contests in which I have ever been engaged. Our great opponents were Mr. Pendelton \& Robert Carter Nicholas, honest men, hut zcalous churchmen. The petitions were referred to the commec of the whole house on the state of the country; and after desperate contests in that committee, almost daily from the $x$ ith of Octob. ${ }^{1}$ to the 5th of December, we prevailed so far only as to repeal the laws which rendered criminal the maintenance of any religious opinions, the forbearance of repairing to church, or the exercise of any mode of worship: and

'An error. These petitions were invariably" refered to the "Committee of Religion" ennsisting of nineteen members (including Jefferson) appointed Oct. 11. 1776. See Jourmal of the House of Delegates. pp. 7. 24. 26. 35.47. On Nov, oth, however, that committee was "discharged" of this question and it was referred to the "Committee of the Whole Inuse upon the State of the Country." 
further, to exempt dissenters from contributions to the support of the established church; and to suspend, only until the next session levies on the members of that church for the salaries of their own incumbents. For although the majority of our citizens were dissenters, as has been observed, a majority of the legislature were churchmen. Among these however were some reasonable and liberal men, who enabled us, on some points, to obtain feeble majorities. But our opponents carried in the general resolutions of the commee of Nov. I9. a declaration that religious assemblies ought to be regulated, and that provision ought to be made for continuing the succession of the clergy, and superintending their conduet. And in the bill now passed ${ }^{\mathrm{I}}$ was inserted an express reservation of the question Whether a general assessment should not be established by law, on every one, to the support of the pastor of his choice; or whether all should be left to voluntary contributions; and on this question, debated at every session from 76 to 79 (some of our dissenting allies, having now secured their particular object, going over to the advocates of a general assessment) we could only obtain a suspension from session to session until 79 . when the question against a general assessment was finally carried, and the establishment of the Anglican

I Entitled: "An Act for exempting the different societies of dissenters from contributing to the support and maintenance of the church as by law established, and its ministers, and for other purposes therein mentioned." Passed by the House of Delegates, Dec. 5th. Concurred in by the Senate Dec. 9th. Re-enacted Jan. 1, 1778 . It is printed in A Collection of Public Acts of Virginia, Richmond, 1785, p. 39 . 
church entirely put down. In justice to the two honest but zealous opponents, who have been named I must add that altho', from their natural temperaments, they were more disposed generally to acquiesce in things as they are, then to risk innovations, yet whenever the public will had once decided, none were more faithful or exact in their obedience to it.

The seat of our government had been originally fixed in the peninsula of Jamestown, the first settlement of the colonists; and had been afterwards removed a few miles inland to Williamsburg. But this was at a time when our settlements had not extended beyond the tide water. Now they had crossed the Alleghany; and the center of population was very far removed from what it had been. Yet Williamsburg was still the depository of our archives, the habitual residence of the Governor \& many other of the public functionaries, the established place for the sessions of the legislature, and the magazine of our military stores: and it's situation was so exposed that it might be taken at any time in war, and, at this time particularly, an enemy might in the night run up either of the rivers between which it lies, land a force above, and take possession of the place, without the possibility of saving either persons or things. I had proposed it's removal so early as Octob. $76 .{ }^{1}$ but it did not prevail until the session of May. '79.

Early in the session of May 79. I prepared, and obtained leave to bring in a bill declaring who should

${ }^{1}$ This was moved as early as $176 r$, and only failed by a vote of 35 to 36 . A second attempt was made Feb. I0, I772.- Journal of the House of Burgesses. Cf. post, Oct. 1 4, 1776. 
be deemed citizens, asserting the natural right of expatriation, and prescribing the mode of exercising it. This, when I withdrew from the house on the Ist of June following, I left in the hands of George Mason and it was passed on the 26 th of that month. ${ }^{\mathrm{I}}$

In giving this account of the laws of which I was myself the mover \& draughtsman, I by no means mean to claim to myself the merit of obtaining their passage. I had many occasional and strentious coadjutors in debate, and one most steadfast, able, and zealous; who was himself a host. This was George Mason, a man of the first order of wisdom among those who acted on the theatre of the revolution, of expansive mind, profound judgment, cogent in argument, learned in the lore of our former constitution, and earnest for the republican change on democratic principles. His elocution was neither flowing nor smooth, but his language was strong, his manner most impressive, and strengthened by a dash of biting cynicism when provocation made it seasonable.

Mr. Wythe, while speaker in the two sessions of I 777. between his return from Congress and his appointment to the Chancery, was an able and constant associate in whatever was before a committee of the whole. His pure integrity, judgment and reasoning powers gave him great weight. Of him see more in some notes inclosed in my letter of August 3I, I82 I, to Mr. John Saunderson.

Mr. Madison came into the House in 1776. a new member and young; which circumstances, concurring

${ }^{1}$ Printed in the Report of the Committee of Revisors, P. 4I. 
with his extreme modesty, prevented his venturing himself in debate before his removal to the Council of State in Nov. 77. From thence he went to Congress, then consisting of few members. Trained in these successive schools, he acquired a habit of self-possession which placed at ready command the rich resources of his luminous and discriminating mind, \& of his extensive information, and rendered him the first of every assembly afterwards of which he became a member. Never wandering from his subject into vain declamation, but pursuing it closely in language pure, classical, and copious, soothing always the feelings of his adversaries by civilities and softness of expression, he rose to the eminent station which he held in the great National convention of I 787 . and in that of Virginia which followed, he sustained the new constitution in all its parts, bearing off the palm against the logic of George Mason, and the fervid declamation of Mr. Henry. With these consummate powers were united a pure and spotless virtue which no calumny has ever attempted to sully. Of the powers and polish of his pen, and of the wisdom of his administration in the highest office of the nation, I need say nothing. They have spoken, and will forever speak for themselves.

So far we were proceeding in the details of reformation only; selecting points of legislation prominent in character \& principle, urgent, and indicative of the strength of the general pulse of reformation. When I left Congress, in 76 . it was in the persuasion that our whole code must be reviewed, adapted to our republican form of government, and, now that we 
had no negatives of Councils, Governors \& Kings to restrain us from doing right, that it should be corrected, in all it's parts, with a single eye to reason, \& the good of those for whose government it was framed. Early therefore ${ }^{1}$ in the session of 76 . to which I returned, I moved and presented a bill for the revision of the laws; which was passed on the 24 th. of October, and on the 5th. of November Mr. Pendleton, Mr. Wythe, George Mason, Thomas L. Lee and myself were appointed a committee to execute the work. We agreed to mect at Fredericksburg to settle the plan of operation and to distribute the work. We met there accordingly, on the I 3 th. of January 1777 . The first question was whether we should propose to abolish the whole existing system of laws, and prepare a new and complete Institute, or preserve the general system, and only modify it to the present state of things. Mr. Pendleton, contrary to his usual disposition in favor of antient things, was for the former proposition, in which he was joined by Mr. Lee. To this it was objected that to abrogate our whole system would be a bold measure, and probably far beyond the views of the legislature; that they had been in the practice of revising from time to time the laws of the colony, omitting the expired, the repealed and the obsolete, amending only those retained, and probably meant we should now do the same, only including the British statutes as well as our own: that to compose a new Institute like those of Justinian and Bracton, or that of Blackstone, which was the model proposed by Mr. Pendleton, would be an arduous

I Oct. I 2 th. Cf. note on this revision, post, under June 18 , 1779 . 
undertaking, of vast research, of great consideration \& judgment; and when reduced to a text, every word of that text, from the imperfection of human language, and it's incompetence to express distinctly every shade of idea, would become a subject of question \& chicanery until settled by repeated adjudications; that this would involve us for ages in litigation, and render property uncertain until, like the statutes of old, every word had been tried, and settled by numerous decisions, and by new volumes of reports \& commentaries; and that no one of us probably would undertake such a work, which, to be systematical, must be the work of one hand. This last was the opinion of Mr. Wythe, Mr. Mason \& myself. When we proceeded to the distribution of the work, Mr. Mason excused himself as, being no lawyer, he felt himself unqualified for the work, and he resigned soon after. Mr. Lee excused himself on the same ground, and died indeed in a short time. The other two gentlemen therefore and myself divided the work among 11s. The common law and statutes to the 4. James I. (when our separate legislature was established) were assigned to me; the British statutes from that period to the present day to Mr. Wythe, and the Virginia laws to Mr. Pendleton. As the law of Descents, \& the criminal law fell of course within my portion, I wished the commee to settle the leading principles of these, as a guide for me in framing them. And with respect to the first, I proposed to abolish the law of primogeniture, and to make real estate descendible in parcenary to the next of kin, as personal property is by the statute of distribution. 
Mr. Pendleton wished to preserve the right of primogeniture, but seeing at once that that could not prevail, he proposed we should adopt the Hebrew principle, and give a double portion to the elder son. I observed that if the eldest son could eat twice as much, or do double work, it might be a natural evidence of his right to a double portion; but being on a par in his powers \& wants, with fis brothers and sisters, he should be on a par also in the partition of the patrimony, and such was the decision of the other members.

On the subject of the Criminal law, all were agreed that the punishment of death should be abolished, except for treason and murder; and that, for other felonies should be substituted hard labor in the public works, and in some cases, the Lex talionis. How this last revolting principle came to obtain our approbation, I do not remember. There remained indeed in our laws a vestige of it in a single case of a slave. it was the English law in the time of the AngloSaxons, copied probably from the Hebrew law of "an eye for an eye, a tooth for a tooth," and it was the law of several antient people. But the modern mind had left it far in the rear of it's advances. These points however being settled, we repaired to our respective homes for the preparation of the work.

Feb. 6. In the execution of my part I thought it material not to vary the diction of the antient statutes by modernizing it, nor to give rise to new questions by new expressions. The text of these statutes had been so fully explained and defined by numerous, 
adjudications, as scarcely ever now to produce a question in our courts. I thought it would be useful a1so, in all new draughts, to reform the style of the later British statutes, and of our own acts of assembly, which from their verbosity, their endless tautologies, their involutions of case within case, and parenthesis within parenthesis, and their multiplied efforts at certainty by saids and aforesaids, by ors and by ands, to make them more plain, do really render them more perplexed and incomprehensible, not only to common readers, but to the lawyers themselves. We were employed in this work from that time to Feb. I779, when we met at Williamsburg, that is to say, Mr. Pendleton, Mr. Wythe \& myself, and meeting day by day, we examined critically our several parts, sentence by sentence, scrutinizing and amending until we had agreed on the whole. We then returned home, had fair copies made of our several parts, which were reported to the General Assembly June i 8. 1 779. by Mr. Wythe and nuself, Mr. Pendleton's residence being distant, and he having authorized us by letter to declare his approbation. We had in this work brought so much of the Common law as it was thought necessary to alter, all the British statutes from Magna Charta to the present day, and all the laws of Virginia, from the establishment of our legislature, in the 4 th. Jac. I. to the present time, which we thought should be retained, within the compass of 126 bills, making a printed folio of 90 pages only. Some bills were taken out occasionally, from time to time, and passed; but the main body of the work was not entered on by the legislature until 
after the general peace, in 1785 . when by the unwearied exertions of Mr. Madison, in opposition to the endless quibbies, chicaneries, perversions, vexations and delays of lawyers and demi-lawyers, most of the bills were passed by the legislature, with little, alteration. ${ }^{1}$

The bill for establishing religious freedom, ${ }^{2}$ the principles of which had, to a certain degree, been enacted before, I had drawn in all the latitude of reason \& right. It still met with opposition; but, with some mutilations in the preamble, it was finally passed; and a singular proposition proved that it's protection of opinion was meant to be universal. Where the preamble declares that coercion is a departure from the plan of the holy author of our religion, an amendment was proposed, by inserting the word "Jesus Christ," so that it should read "a departure from the plan of Jesus Christ, the holy author of our religion" the insertion was rejected by a great majority, in proof that they meant to comprehend, within the mantle of it's protection, the Jew and the Gentile, the Christian and Mahometan, the Hindoo, and infidel of every denomination.

Beccaria and other writers on crimes and punishments had satisfied the reasonable world of the unrightfulness and inefficacy of the punishment of crimes by death; and hard labor on roads, canals and other public works, had been stiggested as a proper substitute. The Revisors had adopted these

I See Correspondence of James Madison, i., r 99, 203, 207, 2 I 2 ; iii., 532, $580,583,612$.

2 Printed in this edition under June 18 , I 779 . 
opinions; but the general idea of our country had not yet advanced to that point. The bill therefore for proportioning crimes and punishments was lost in the House of Delegates by a majority of a single vote. I I learnt afterwards that the substitute of hard labor in public was tried (I believe it was in Pennsylvania) without success. Exhibited as a public spectacle, with shaved heads and mean clothing, working on the high roads produced in the criminals such a prostration of character, such an abandonment of self-respect, as, instead of reforming, plunged them into the most desperate $\&$ hardened depravity of morals and character.-To pursue the subject of this law.- I was written to in 1785 (being then in Paris) by Directors appointed to superintend the building of a Capitol in Richmond, to advise them as to a plan, and to add to it one of a prison. Thinking it a favorable opportunity of introducing into the state an example of architecture in the classic style of antiquity, and the Maison quarrée of Nismes, an antient Roman temple, being considered as the

I "We went on slowly but successfully till we arrived at the bill concerning crimes and punishments. Here the adversaries of the Code exerted their whole force, which, being abetted by the impatience of its friends in an advanced stage of the session, so far prevailed that the farther prosecution of the work was postponed till the next session." -Madison to Jefferson, Jamuary 22, 1786. "After being altered so as to remove most of the objections, as was thought [it] was lost by a single vote. The rage against Horse-stealers had a great influence on the fate of the bill. Our old bloody code is by this event fully restored."-Madison to Jefferson, February 15, I787. "In the changes made in the penal law, the Revisors were unfortunately misled into some of the specious errors of - [Beccaria] then in the zenith of his fame as a philosophical legislator." -Madison to Grimke, Jamuary I5, I 828 . 
most perfect model existing of what may be called Cubic architecture, I applied to M. Clerissault, who had published drawings of the Antiquities of Nismes, to have me a model of the building made in stucco, only changing the order from Corinthian to Ionic, on account of the difficulty of the Corinthian capitals. I yielded with reluctance to the taste of Clerissault, in his preference of the modern capital of Scamozzi to the more noble capital of antiquity. This was executed by the artist whom Choiseul Gouffier had carried with him to Constantinople, and employed while Ambassador there, in making those beautiful models of the remains of Grecian architecture which are to be seen at Paris. To adapt the exterior to our use, I drew a plan for the interior, with the apartments necessary for legislative, executive $\&$ judiciary purposes, and accommodated in their size and distribution to the form and dimensions of the building. These were forwarded to the Directors in I 786 . and were carried into execution, with some variations not for the better, the most important of which however admit of future correction. With respect to the plan of a Prison, requested at the same time, I had heard of a benevolent society in England which had been indulged by the government in an experiment of the effect of labor in solitary confinement on some of their criminals, which experiment had succeeded beyond expectation. The same idea had been suggested in France, and an Architect of Lyons had proposed a plan of a well contrived edifice on the principle of solitary confinement. I procured a copy, and as it was too large 
for our purposes, I drew one on a scale, less extensive, but susceptible of additions as they should be wanting. This I sent to the Directors instead of a plan of a common prison, in the hope that it would suggest the idea of labor in solitary confinement instead of that on the public works, which we had adopted in our Revised Code. It's principle accordingly, but not it's exact form, was adopted by Latrobe in carrying the plan into execution, by the erection of what is now called the Penitentiary, built under his direction. In the meanwhile the public opinion was ripening by time, by reflection, and by the example of Pensylva, where labor on the highways had been tried without approbation from I 786 to 89 . \& had been followed by their Penitentiary system on the principle of confinement and labor, which was proceeding auspiciously. In I 796. our legislature resumed the subject and passed the law for amending the Penal laws of the commonwealth. They adopted solitary, instead of public labor, established a gradation in the duration of the confinement, approximated the style of the law more to the modern usage, and instead of the settled distinctions of murder \& manslaughter, preserved in my bill, they introduced the new terms of murder in the Ist $\& 2 \mathrm{~d}$ degree. Whether these have produced more or fewer questions of definition I am not sufficiently informed of our judiciary transactions to say. I will here however insert the text of my bill, with the notes I made in the course of my researches into the subject. ${ }^{\mathrm{T}}$

I Printed in this edition under June $18,1779$. 
Feb. 7. The acts of assembly concerning the College of Wm. \& Mary, were properly within Mr. Pendleton's portion of our work. But these related chiefly to it's revenue, while it's constitution, organization and scope of science were derived from it's charter. We thought, that on this subject a systematical plan of general education should be proposed, and I was requested to undertake it. I accordingly prepared three bills for the Revisal, proposing three distinct grades of education, reaching all classes. ${ }^{\mathrm{I}} \quad$ I. Elementary schools for all children generally, rich and poor. 2. Colleges for a middle degree of instruction, calculated for the common purposes of life, and such as would be desirable for all who were in easy circumstances. And $3 \mathrm{~d}$. an ultimate grade for teaching the sciences generally, $\&$ in their highest degree. The first bill proposed to lay off every county into Hundreds or Wards, of a proper size and population for a school, in which reading, writing, and common arithmetic should be taught; and that the whole state should be divided into 24 districts, in each of which should be a school for classical learning, grammar, geography, and the higher branches of numerical arithmetic. The secand bill proposed to amend the constitution of $\mathrm{Wm}$. $\&$ Mary College, to enlarge it's sphere of science, and to make it in fact an University. The third was for the establishment of a library. These bills were not acted on until the same year ' 96 . and then only so much of the first as provided for elementary schools. The College of Wm. \& Mary was an establishment

$$
\text { I Printed in this edition under June I8, I779. }
$$


purely of the Church of England, the Visitors were required to be all of that Church; the Professors to subscribe it's 39 Articles, it's Students to learn it's Catechism, and one of its fundamental objects was (leclared to be to raise up Ministers for that church. The religious jealousies therefore of all the dissenters took alarm lest this might give an ascendancy to the Anglican sect and refused acting on that bill. Its local eccentricity too and unhealthy autumnal climate lessened the general inclination towards it. And in the Elementary bill they inserted a provision which completely defeated it, for they left it to the court of each county to determine for itself when this act should be carried into execution, within their county. One provision of the bill was that the expenses of these schools should be borne by the inhabitants of the county, every one in proportion to his general tax-rate. This would throw on wealth the education of the poor; and the justices, being generally of the more wealthy class, were unwilling to incur that burthen, and I believe it was not suffered to commence in a single county. I shall recur again to this subject towards the close of my story, if I should have life and resolution enough to reach that term; for I am already tired of talking about myself.

The bill on the subject of slaves was a mere digest of the existing laws respecting them, without any intimation of a plan for a future \& general emancipation. It was thought better that this should be kept back, and attempted only by way of amendment whenever the bill should be brought on. ${ }^{1}$ The prinI Cf. post, with Notes on Virginia in this edition. 
ciples of the amendment however were agreed on, that is to say, the freedom of all born after a certain day, and deportation at a proper age. But it was found that the public mind would not yet bear the proposition, nor will it bear it eren at this day. Yet the day is not distant when it must bear and adopt it, or worse will follow. Nothing is more certainly written in the book of fate than that these people are to be free. Nor is it less certain that the two races, equally free, cannot live in the same government. Nature, habit, opinion has drawn indelible lines of distinction between them. It is still in our power to direct the process of emancipation and deportation peaceably and in such slow degree as that the evil will wear off insensibly, and their place be pari passu filled up by free white laborers. If on the contrary it is left to force itself on, human nature must shudder at the prospect held up. We should in vain look for an example in the Spanish deportation or deletion of the Moors. This precedent would fall far short of our case.

I consiclered 4 of these bills, passed or reported, as forming a system by which every fibre would be eradicated of antient or future aristocracy; and a foundation laid for a government truly republican. The repeal of the laws of entail would prevent the accumulation and perpetuation of wealth in select families, and preserve the soil of the country from being daily more \& more absorbed in Mortmain. The abolition of primogeniture, and equal partition of inheritances removed the feudal and unnatural distinctions which made one member of every family 
rich, and all the rest poor, substituting equal partition, the best of all Agrarian laws. The restoration of the rights of conscience relieved the people from taxation for the support of a religion not theirs; for the establishment was truly of the religion of the rich, the dissenting sects being entirely composed of the less wealthy people; and these, by the bill for a general education, would be qualified to understand their rights, to maintain them, and to exercise with intelligence their parts in self-government: and all this would be effected without the violation of a single natural right of any one individual citizen. To these too might be added, as a further seeurity, the introduction of the trial by jury, into the Chancery courts, which have already ingulfed and continue to ingulf, so great a proportion of the jurisdiction over our property.

On the ist of June I 779. I was appointed Governor of the Commonwealth and retired from the legislature. Being elected also one of the Visitors of Wm. \& Mary college, a self-electing body, I effected, during my residence in Williamsburg that year, a change in the organization of that institution by abolishing the Grammar school, and the two professorships of Divinity \& Oriental languages, and substituting a professorship of Law \& Police, one of Anatomy Medicine and Chemistry, and one of Modern languages; and the charter confining us to six professorships, ${ }^{\mathrm{I}}$ we added the law of Nature \& Nations, \& the Fine Arts to the duties of the Moral professor, and Natural history to those of the professor of Mathematics and Natural philosophy.

${ }^{1} C f$. post, with Notes on Virginia in this edition. 
Being now, as it were, identified with the Commonwealth itself, to write my own history during the two years of my administration, would be to write the public history of that portion of the revolution within this state. This has been done by others, and particularly by Mr. Girardin, who wrote his Continuation of Burke's history of Virginia while at Milton, in this neighborhood, had free access to all my papers while composing it, and has given as faithful an account as I could myself. For this portion therefore of nyy own life, I refer altogether to his history. From a belief that under the pressure of the invasion under which we were then laboring the public would have more confidence in a Military chief, and that the Military commander, being invested with the Civil power also, both might be wielded with more energy promptitude and effect for the defence of the state, I resigned the administration at the end of my $2 \mathrm{~d}$. year, and General Nelson was appointed to succeed me.

Soon after my leaving Congress in Sep. ' 76 , to wit

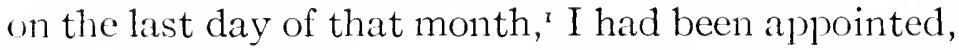
with Dr. Franklin, to go to France, as a Commissioner to negotiate treaties of alliance and commerce with that government. Silas Deane, then in France, acting as agent " for procuring military stores, was

I An error. He was appointed Sept. 26th,- -Secret Journals of Congress, ii., $3 \mathrm{I}$.

${ }^{2}$ His ostensible character was to be that of a merchant, his real one that of agent for military supplies, and also for sounding the dispositions of the government of France, and seeing how far they would favor us, either secretly or openly. ILis appointment had been by the Committee of Foreign Correspondence, March, i 776.-T. J. 
joined with us in commission. But such was the state of my family that I could not leave it, nor could I expose it to the dangers of the sea, and of capture by the British ships, then covering the ocean. I saw too that the laboring oar was really at home, where much was to be done of the most permanent interest in new modelling our governments, and much to defend our fanes and fire-sides from the desolations of an invading enemy pressing on our country in every point. I declined therefore and Dr. Lee was appointed in my place. On the I5th. of June ${ }^{\mathrm{I}}$ 78 $\mathrm{I}$. I had been appointed with $\mathrm{Mr}$. Adams, Dr. Franklin, Mr. Jay, and Mr. Laurens a Minister plenipotentiary for negotiating peace, then expected to be effected thro' the mediation of the Empress of Russia. The same reasons obliged me still to decline; and the negotiation was in fact never entered on. But, in the autumn of the next year 1782 Congress receiving assurances that a general peace would be concluded in the winter and spring, they renewed my appointment on the $\mathrm{r} 3$ th. of Nov. of that year. I had two months before that lost the cherished companion of my life, in whose affections, unabated on both sides I had lived the last ten years in unchequered happiness. With the public interests, the state of my mind concurred in recommending the change of scene proposed; and I accepted the appointment, and left Monticello on the rgth. of Dec. I 782 . for Philadelphia, where I arrived on the 27 th. The Minister of France, Luzerne, offered me a passage in the Romulus frigate,

I By the Secret Journal of Congress it was June I 4 th. 
which I accepting. But she was then lying a few miles below Baltimore blocked up in the ice. I remained therefore a month in Philadelphia, looking over the papers in the office of State in order to possess myself of the general state of our foreign relations, and then went to Baltimore to await the liberation of the frigate from the ice. After waiting there nearly a month, we received information that a Provisional treaty of peace had been signed by our Commissioners on the $3 \mathrm{~d}$. of Sep. I782. to become absolute on the conclusion of peace between France and Great Britain. Considering my proceeding to Europe as now of no utility to the public, I returned immediately to Philadelphia to take the orders of Congress, and was excused by them from further proceeding. I therefore returned home, where I arrived on the $5_{5}$ th. of May, 1783 .

On the 6 th. of the following month I was appointed by the legislature a delegate to Congress, the appointment to take place on the ist. of Nov. ensuing, when that of the existing delegation would expire. I accordingly left home on the 16 th. of Oct. arrived at Trenton, where Congress was sitting, on the $3 \mathrm{~d}$. of Nov. and took my seat on the 4th., on which day Congress adjourned to meet at Annapolis on the 26th.

Congress had now become a very small body, and the members very remiss in their attendance on it's duties insomuch that a majority of the states, necessary by the Confederation to constitute a house even for minor business did not assemble until the r 3 th. of December.

They as early as Jan. 7. I 782. had turned their rol. 1. -6 . 
attention to the monies current in the several states, and had directed the Financier, Robert Morris, to report to them a table of rates at which the foreign coins should be received at the treasury. That officer, or rather his assistant, Gouverneur Morris, answered them on the ${ }_{5}{ }^{\text {th }}{ }^{2}$ in an able and elaborate statement of the denominations of money current in the several states, and of the comparative value of the foreign coins chiefly in circulation with us. $\mathrm{He}$ went into the consideration of the necessity of establishing a standard of value with us, and of the adoption of a money-Unit. He proposed for the Unit such a fraction of pure silver as would be a common measure of the penny of every state, without leaving a fraction. This common divisor he found to be I-I 440 of a dollar, or I-I 600 of the crown sterling. The value of a dollar was therefore to be expressed by 1440 units, and of a crown by $\mathrm{I} 600$. Each unit containing a quarter of a grain of fine silver. Congress turning again their attention to this subject the following year, the financier, by a letter of Apr. 30, I783. further explained and urged the Unit he had proposed; but nothing more was done on it until the ensuing year, when it was again taken up, and referred to a commee of which I was a member. The general views of the financier were sound, and the principle was ingenious on which he proposed to found his Unit. But it was too minute for ordinary use, too laborious for computation either by the head or in figures. The price of a loaf of bread $I-20$ of a dollar would be 72 . units.

¿Diplomatic Correspondence, xii., $8 \mathrm{r}$. 
A pound of butter $I_{-5} 5$ of a dollar 288 . units.

A horse or bitllock of 80 . D value would require a notation of 6 . figures, to wit I I 5,200 , and the public debt, suppose of 80 . millions, would require i 2 . figures, to wit I I5,200,000,000 units. Such a system of money-arithmetic would be entirely unmanageable for the common purposes of society. I proposed therefore, instead of this, to adopt the Dollar as our Unit of account and payment, and that it's divisions and sub-divisions should be in the decimal ratio. I wrote some Notes ' on the strbject, which I submitted to the consideration of the financier. I received his answer and adherence to his general system, only agreeing to take for his Unit roo. of those he first proposed, so that a Dollar should be I 4 40-100 and a crown I6. units. I replied to this and printed my notes and reply on a flying sheet, which I put into the hands of the members of Congress for consideration, and the Committee agreed to report on my principle. This was adopted the ensuing year and is the system which now prevails. I insert here the Notes and Reply, as shewing the different views on which the adoption of our money system hung. The division into dimes, cents \& mills is now so well understood, that it would be easy of introduction into the kindred branches of weights \& measures. I use, when I travel, an Odometer of Clarke's invention which divides the mile into cents, and I find every one comprehend a distance readily when stated to them in miles \& cents; so they would in feet and cents, pounds \& cents, \&c.

${ }^{1}$ Printed in this edition under ${ }_{17} 84$. 
The remissness of Congress, and their permanent session, began to be a subject of uneasiness and even some of the legislatures had recommended to them intermissions, and periodical sessions. As the Confederation had made no provision for a visible head of the government during vacations of Congress, and such a one was necessary to superintend the exccutive business, to receive and communicate with foreign ministers \& nations, and to assemble Congress on sudden and extraordinary emergencies, I proposed early in April ${ }^{1}$ the appointment of a commee to be called the Committee of the states, to consist of a member from each state, who should remain in session during the recess of Congress: that the functions of Congress should be divided into Executive and Legislative, the latter to be reserved, and the former, by a general resolution to be delegated to that Committee. This proposition was afterwards agreed to; a Committee appointed, who entered on duty on the subsequent adjournment of Congress, quarrelled very soon, split into two parties, abandoned their post and left the government without any visible head until the next meeting in Congress. We have since seen the same thing take place in the Directory of France; and I believe it will forever take place in any Executive consisting of a plurality. Our plan, best I believe, combines wisdom and practicability, by providing a plurality of Counsellors, but a single Arbiter for ultimate decision. I was in France when we heard of this schism,

1 April I 4, 1784. Journal of Congress, ix., i 27. Cf. post, under Jan. 30, i $; 8_{4}$. Jefferson's report on the committee of the States. 
and separation of our Committee, and, speaking with Dr. Franklin of this singular disposition of men to quarrel and divide into parties, he gave his sentiments as usual by way of Apologue. He mentioned the Eddystone lighthouse in the British channel as being built on a rock in the mid-channel, totally inaccessible in winter, from the boisterous character of that sea, in that season. That therefore, for the two keepers employed to keep up the lights, all provisions for the winter were necessarily carried to them in autumn, as they could never be visited again till the return of the milder season. That on the first practicable day in the spring a boat put off to them with fresh supplies. The boatmen met at the door one of the keepers and accosted him with a How goes it friend? Very well. How is your companion? I do not know. Don't know? Is not he here? I can't tell. Have not you seen him to-day? No. When did you see him? Not since last fall. You have killed him? Not I, indeed. They were about to lay hold of him, as having certainly murdered his companion; but he desired them to go up stairs \& examine for themselves. They went up, and there found the other keeper. They had quarrelled it seems soon after being left there, had divided into two parties, assigned the cares below to one, and those above to the other, and had never spoken to or seen one another since.

But to return to our Congress at Annapolis, the refinitive treaty of peace which had been signed at Paris on the $3 \mathrm{~d}$. of Sep. I783. and received here, could not be ratified without a House of 9. states."

\footnotetext{
${ }^{1} \mathrm{Cf}$. post, under Jan., ${ }^{7} 84$.
} 
On the 23 d. of Dec. ${ }^{\mathrm{x}}$ therefore. we addressed letters to the several governors, stating the receipt of the definitive treaty, that 7 states only were in attendance, while 9. were necessary to its ratification, and urging them to press on their delegates the necessity of their immediate attendance. And on the 26th. to save time I moved that the Agent of Marine (Robert Morris) should be instructed to have ready a vessel at this place, at N. York, \& at some Eastern port, to carry over the ratification of the treaty when agreed to. It met the general sense of the house, but was opposed by Dr. Lee ${ }^{2}$ on the ground of expense which it would authorize the agent to incur for us; and he said it would be better to ratify at once $\&$ send on the ratification. Some members had before suggested that 7 states were competent to the ratification. My motion was therefore postponed and another brought forward by $\mathrm{Mr}$. Read ${ }^{3}$ of S. C. for an immediate ratification. This was debated the 26 th. and 27 th. Reed, Lee, [Hugh] Williamson is Jeremiah Chace urged that ratification was a mere matter of form, that the treaty was conclusive from the moment it was signed by the ministers; that although the Confederation requires the assent of 9. states to enter into a treaty, yet that it's conclusion could not be called entrance into it; that supposing 9. states requisite, it would be in the power of 5 . states to keep us always at war; that 9. states had virtually authorized the ratifion having ratified

I On motion of Williamson, seconded by Jefferson.

2 Arthur Lee, Delegate from Virginia.

3 Jacob Read. 
the provisional treaty, and instructed their ministers to agrec to a definitive one in the same terms, and the present one was in fact substantially and almost verbatim the same; that there now remain but 67 . days for the ratification, for it's passage across the Atlantic, and it's exchange; that there was no hope of our soon having 9. states present; in fact that this was the ultimate point of time to which we could venture to wait; that if the ratification was not in Paris by the time stipulated, the treaty would become void; that if ratified by 7 states, it would go under our seal without it's being known to $\mathrm{Gr}$. Britain that only 7 . had concurred; that it was a question of which they had no right to take cognizance, and we were only answerable for it to oul constituents; that it was like the ratification which Gr. Britain had received from the Dutch by the negotiations of Sr. Wm. Temple.

On the contrary, it was argued by Monroe, Gerry, Howel, Ellery \& myself that by the modern usage of Europe the ratification was considered as the act which gave validity to a treaty, until which it was not obligatory. ${ }^{x}$ 'That the commission to the ministers reserved the ratification to Congress; that the treaty itself stipulated that it should be ratified; that it became a $2 \mathrm{~d}$. question who were competent to the ratification? That the Confederation expressly required 9 states to enter into any treaty; that, by this, that instrument must have intended that the assent of 9. states should be necessary as T. $J$.

L. 4, $\$ 77 . \quad$ I. Mably Droit D'Europe, 86.- 
well to the completion as to the commencement of the treaty, it's object having been to guard the rights of the Union in all those important cases where 9 . states are called for; that, by the contrary construction, 7 states, containing less than one third of our whole citizens, might rivet on us a treaty, commenced indeed under commission and instructions from 9. states, but formed by the minister in express contradiction to such instructions, and in direct sacrifice of the interests of so great a majority; that the definitive treaty was admitted not to be a verbal copy of the provisional one, and whether the departures from it were of substance or not, was a question on which 9. states alone were competent to decide; that the circumstances of the ratification of the provisional articles by 9 . states the instructions to our ministers to form a definitive one by them, and their actual agreement in substance, do not render us competent to ratify in the present instance; if these circumstances are in themselves a ratification, nothing further is requisite than to give attested copies of them, in exchange for the British ratification; if they are not, we remain where we were, without a ratification by 9 . states, and incompetent ourselves to ratify; that it was but 4 . days since the seven states now present unanimously concurred in a resolution to be forwarded to the governors of the absent states, in which they stated as a cause for urging on their delegates, that 9. states were necessary to ratify the treaty; that in the case of the Lutch ratification, Gr. Britain had courted it, and therefore was glad to accept it as it was; that 
they knew our constitution, and would object to a ratification by 7 . that if that circumstance was kept lack, it would be known hereafter, \& would give them ground to deny the validity of a ratification into which they should have been surprised and cheated, and it would be a dishonorable prostitution of our seal; that there is a hope of 9 . states; that if the treaty would become null if not ratified in time, it would not be saved by an imperfect ratification; but that in fact it would not be null, and would be placed on better ground, gring in unexceptionable form, thr' a few days tor late, and rested on the small importance of this circumstance, and the physical impossibilities which had prevented a punctual compliance in point of time; that this would be approved by all nations, \& by Great Britain herself, if not determinced to renew the war, and if determined, she would never want excuses, were this out of the way. Mr. Reade gave notice he should call for the yeas \& nays; whereon those in opposition prepared a resolution expressing pointedly the reasons of the dissent from his motion. It appearing however that his proposition could not be carried, it was thought better to make no entry at all. Massachusetts alone would have been for it; Rhode Island, Pennsylvania and Virginia against it, Delaware, Maryland \& $\mathrm{N}$. Carolina, would have been divided.

Our body was little numerous, but very contentious. Day after day was wasted on the most unimportant questions. My colleague Mercer ' was one of those afflicted with the morbid rage of debate,

I John F. Mercer. 
well to the completion as to the commencement of the treaty, it's object having been to guard the rights of the Union in all those important cases where 9 . states are called for; that, by the contrary construction, 7 states, containing less than one third of our whole citizens, might rivet on us a treaty, commenced indeed under commission and instructions from 9. states, but formed by the minister in express contradiction to such instructions, and in direct sacrifice of the interests of so great a majority; that the definitive treaty was admitted not to be a verbal copy of the provisional one, and whether the departures from it were of substance or not, was a question on which 9. states alone were competent to decide; that the circumstances of the ratification of the provisional articles by 9 . states the instructions to our ministers to form a definitive one by them, and their actual agreement in substance. do not render us competent to ratify in the present instance; if these circumstances are in themselves a ratification, nothing further is requisite than to give attested copies of them, in exchange for the British ratification; if they are not, we remain where we were, without a ratification by 9 . states, and incompetent ourselves to ratify; that it was but 4 . days since the seren states now present unanimously concurred in a resolution to be forwarded to the governors of the absent states, in which they stated as a cause for urging on their delegates, that 9. states were necessary to ratify the treaty; that in the case of the Dutch ratification, Gr. Britain had courted it, and therefore was glad to accept it as it was; that 
they knew our constitution, and would object to a ratification by 7 . that if that circumstance was kept loack, it would be known hereafter, \& would give them ground to deny the validity of a ratification into which they should have been surprised and cheated, and it would be a dishonorable prostitution of our seal; that there is a hope of 9 . states; that if the treaty would become null if not ratified in time, it would not be saved by an imperfect ratification; but that in fact it would not be null, and would be placed on better ground, going in unexceptionable form, tho' a few days too late, and rested on the small importance of this circumstance, and the physical impossibilities which had prevented a punctual compliance in point of time; that this would be approved by all nations, \& by Great Britain herself, if not determined to renew the war, and if determined, she would never want excuses, were this out of the way. Mr. Reade gave notice he should call for the yeas \& nays; whereon those in opposition prepared a resolution expressing pointedly the reasons of the dissent from his motion. It appearing however that his proposition could not be carried, it was thought better to make no entry at all. Massachusetts alone would have been for it; Rhode Island, Pennsylvania and Virginia against it, Delaware, Maryland \& N. Carolina, would have been divided.

Our body was little numerous, but very contentious. Day after day was wasted on the most unimportant questions. My colleague Mercer $^{\mathrm{I}}$ was one of those afflicted with the morbid rage of debate,

' John F. Mercer. 
debated on the 3 d. and 4 th.' and on the 5 th. a vessel being to sail for England from this port (Annapolis) the House directed the President to write to our ministers accordingly.

Jan. I4. Delegates from Connecticut having attended yesterday, and another from S. Carolina coming in this day, the treaty was ratified without a dissenting voice, and three instruments of ratification were ordered to be made out, one of which was sent by Colo. Harmer, another by Colo. Franks, and the $3 \mathrm{~d}$. transmitted to the agent of Marine to be forwarded by any good opportunity.

Congress soon took up the consideration of their foreign relations. They deemed it necessary to get their commerce placed with every nation on a footing as favorable as that of other nations; and for this purpose to propose to each a distinct treaty of commerce. This act too would amount to an acknowledgment by each of our independance and of our reception into the fraternity of nations; which altho', as possessing our station of right and in fact, we would not condescend to ask, we were not unwilling to furnish opportunities for receiving their friendly salutations \& welcome. With France the United Netherlands and Sweden we had already treaties of commerce, but commissions were given for those countries also, should any amendments be thought necessary. The other states to which treaties were to be proposed were England, Hamhurg, Saxony, Prussia, Denmark, Russia, Austria, Venice, Rome, Naples, Tuscany, Sardinia, Genoa,

I The ${ }_{4}$ th of January, 1784 , was Sunday, so Congress did not sit. 
Spain, Portugal, the Porte, Algiers, Tripoli, 'Tunis \& Morocco.'

Mar. i6. On the gth. of May Congress resolved that a Minister Plenipotentiary should be appointed in addition to Mr. Adams \& Dr. Franklin for negntiating treaties of commerce with foreign nations, and I was elected to that duty. I accordingly left Annapolis on the ith. Took with me my elder daughter $^{2}$ then at Philadelphia (the two others being too young for the voyage) \& proceeded to Boston in quest of a passage. While passing thro' the rifferent states, I made a point of informing myself of the state of the commerce of each, went on to New Hampshire with the same view and returned to Boston. From thence I sailed on the 5th. of July in the Ceres a merchant ship of Mr. Nathaniel Tracey, bound to Cowes. He was himself a passenger, and, after a pleasant voyage of 19 . days from land to land, we arrived at Cowes on the 26th. I was detained there a few days by the indisposition of my daughter. On the 3oth. we embarked for Havre, arrived there on the 3 Ist. left it on the $3 \mathrm{~d}$. of August, and arrived at Paris on the 6th. I called immediately on Doctr. Franklin at Passy, communicated to him our charge, and we wrote to $\mathrm{Mr}$. Adams, then at the Hague to join us at Paris.

Before I had left America, that is to say in the year I78I. I had received a letter from M. de Marbois, of the French legation in Philadelphia, informing me he had been instructed by his government to

${ }^{1}$ See Jefferson's report on European treaties, post, under 1784 .

${ }^{2}$ Martha Jefferson, afterwards Mrs. Thomas Mann Randolph. 
obtain such statistical accounts of the different states of our Union, as might be useful for their information; and addressing to me a number of queries relative to the state of Virginia. I had always made it a practice whenever an opportunity occurred of obtaining any information of our country, which might be of use to me in any station public or private, to commit it to writing. These memoranda were on loose papers, bundled up without order, and difficult of recurrence when I had occasion for a particular one. I thought this a good occasion to cmbody their substance, which I did in the order of Mr. Marbois' queries, so as to answer his wish and to arrange them for my own use. Some friends to whom they were occasionally communicated wished for copies; but their volume rendering this too laborious by hand, I proposed to get a few printed for their gratification. I was asked such a price however as exceeded the importance of the object. On my arrival at Paris I found it could be done for a fourth of what I had been asked here. I therefore corrected and enlarged them, and had 200. copies printed, under the title of Notes on Virginia. I gave a very few copies to some particular persons in Europe, and sent the rest to my friends in America. An European copy, by the death of the owner, got into the hands of a bookseller, who engaged it's translation, \& when ready for the press, communicated his intentions \& manuscript to me, without any other permission than that of suggesting corrections. I never had seen so wretched an attempt at translation. Interverted, abridged, mutilated, and 
often reversing the sense of the original, I found it a blotch of errors from beginning to end. I corrected some of the most material, and in that form it was printed in French.' A London bookseller, on seeing the translation, requested me to permit him to print the English original. I thought it best to do so to let the world see that it was not really so bad as the French translation had made it appear. And this is the true history of that publication.

Mr. Adams soon joined us at Paris, \& our first employment was to prepare a general form to be proposed to such nations as were disposed to treat with us. During the negotiations for peace with the British Commissioner David Hartley, our Commissioners had proposed, on the suggestion of Doctr. Franklin, to insert an article exempting from capture by the public or private armed ships of either belligerent, when at war, all merchant vessels and their cargoes, employed merely in carrying on the commerce between nations. It was refused by England, and unwisely, in my opinion. For in the case of a war with us, their superior commerce places infinitely more at hazard on the ocean than ours; and as hawks abound in proportion to game, so our privateers would swarm in proportion to the wealth exposed to their prize, while theirs would be few for want of subjects of capture. We inserted this article in our form, with a provision against the molestation of fishermen, husbandmen, citizens unarmed and following their occupations in unfortified places, for the humane treatment of prisoners of war,

I Cf. post, note on Notes on V'irginia under I $_{7} 82$. 
the abolition of contraband of war, which exposes merchant vessels to such vexatious \& ruinous detentions and abuses; and for the principle of free bottoms, free goods.

In a conference with the Count de Vergennes, it was thought better to leave to legislative regulation on both sides such modifications of our commercial intercourse as would voluntarily flow from amicable dispositions. Without urging, we sounded the ministers of the several European nations at the court of Versailles, on their dispositions towards mutual commerce, and the expediency of encouraging it by the protection of a treaty. Old Frederic of Prussia met us cordially and without hesitation, and appointing the Baron de Thulemeyer, his minister at the Hague, to negotiate with us, we communicated to him our Project, which with little alteration by the King, was soon concluded. Denmark and Tuscany entered also into negotiations with us. Other powers appearing indifferent we did not think it proper to press them. They seemed in fact to know little about us, but as rebels who had been successful in throwing off the yoke of the mother country. They were ignorant of our commerce, which had been always monopolized by England, and of the exchange of articles it might offer advantageously to both parties. They were inclined therefore to stand aloof until they could see better what relations might be usefully instituted with us. The negotiations therefore begun with Denmark \& Tuscany we protracted designedly until our powers had expired; and abstained from making new propositions to 
others having no colonies; because our commerce being an exchange of raw for wrought materials, is a competent price for admission into the colonies of those possessing them: but were we to give it, without price, to others, all would claim it without price on the ordinary ground of gentis amicissimæ.

Mr. Adams being appointed Min. Pleny. of the U S. to London, left us in June, and in July I 785 . Dr. Franklin returned to America, and I was appointed his stuccessor at Paris. In Feb. I 786. Mr. Adams wrote to me pressingly to join him in London immediately, as he thought he discovered there some symptoms of better disposition towards us. Colo. Smith,' his Secretary of legation, was the bearer of his urgencies for my immediate attendance. I accordingly left Paris on the ist. of March, and on my arrival in London we agreed on a very summary form of treaty, proposing an exchange of citizenship for our citizens, our ships, and our productions generally, except as to office. On my presentation as usual to the King and Queen at their levées, it was impossible for anything to be more ungracious than their notice of $\mathrm{Mr}$. Adams \& myself. I saw at once that the ulcerations in the narrow mind of that mulish being left nothing to be expected on the subject of my attendance; and on the first conference with the Marquis of Caermarthen, his Minister of foreign affairs, the distance and disinclination which he betrayed in his conversation, the vagueness $\&$ evasions of his answers to us, confirmed me in the belief of their aversion to have anything to do with us. We 'William Stephens Smith.

VOL. 1. $\rightarrow$. 
delivered him however our Projét, Mr. Adams not despairing as much as I did of it's effect. We afterwards, by one or more notes, requested his appointment of an interview and conference, which, without directly declining, he evaded by pretences of other pressing occupations for the moment. After staying there seven weeks, till within a few days of the expiration of our commission, I informed the minister by note that my duties at Paris required my return to that place, and that I should with pleasure be the bearer of any commands to his Ambassador there. He answered that he had none, and wishing me a pleasant journey, I left London the 26 th. arrived at Paris on the zoth. of April.

While in London we entered into negotiations with the Chevalier Pinto, Ambassador of Portugal at that place. The only article of difficulty between us was a stipulation that our bread stuff should be received in Portugal in the form of flour as well as of grain. He approved of it himself, but observed that several Nobles, of great influence at their court, were the owners of wind mills in the neighborhood of Lisbon which depended much for their profits on manufacturing our wheat, and that this stipulation would endanger the whole treaty. He signed it however, \& it's fate was what he had candidly portended.

My duties at Paris were confined to a few objects; the receipt of our whale-oils, salted fish, and salted meats on favorable terms, the admission of our rice on equal terms with that of Piedmont, Egypt \& the Levant, a mitigation of the monopolies of our tobacco by the Farmers-general, and a free admission of our 
productions into their islands; were the principal commercial objects which required attention; and on these occasions I was powerfully aided by all the influence and the energies of the Marquis de La Fayette, who proved himself equally zealous for the friendship and welfare of both nations; and in justice I must also say that I found the government entirely disposed to befriend us on all occasions, and to yield us every indulgence not absolutely injurious to themselves. The Count de Vergennes had the reputation with the diplomatic corps of being wary \& slippery in his diplomatic intercourse; and so he might be with those whom he knew to be slippery and double-faced themselves. As he saw that I had no indirect views, practised no subtleties, meddled in no intrigues, pursued no concealed object, I found him as frank, as honorable, as easy of access to reason as any man with whom I had ever done business; and I must say the same for his successor Montmorin, one of the most llonest and worthy of human beings.

Our commerce in the Mediterranean was placed under early alarm by the capture of two of our vessels and crews by the Barbary cruisers. I was very unwilling that we should acquiesce in the European humiliation of paying a tribute to those lawless pirates, and endeavored to form an association of the powers subject to habitual depredation from them. I accordingly prepared and proposed to their ministers at Paris, for consultation with their governments, articles of a special confederation in the following form. 
"Proposals for concerted operation among the powers at war with the Piratical States of Barbary.

" I. It is proposed that the several powers at war with the Piratical States of Barbary, or any two or more of them who shall be willing, shall enter into a convention to carry on their operations against those states, in concert, beginning with the Algerines.

" 2 . This convention shall remain open to any other power who shall at any future time wish to accede to it; the parties reserving a right to prescribe the conditions of such accession, according to the circumstances existing at the time it shall be proposed.

"3. The object of the convention shall be to compel the piratical states to perpetual peace, without price, \& to guarantee that peace to each other.

"4. The operations for obtaining this peace shall be constant cruises on their coast with a naval force now to be agreed on. It is not proposed that this force shall be so considerable as to be inconvenient to any party. It is believed that half a dozen frigates, with as many Tenders or Xebecs, one half of which shall be in cruise, while the other half is at rest, will suffice.

" 5 . The force agreed to be necessary shall be furnished by the parties in certain quotas now to be fixed; it being expected that each will be willing to contribute in such proportion as circumstance may render reasonable.

"6. As miscarriages often proceed from the want of harmony among officers of different nations, the parties shall now consider \& decide whether it will 
not be better to contribute their quotas in money to be employed in fitting out, and keeping on duty, a single fleet of the force agreed on.

"7. The difficulties and delays too which will attend the management of these operations, if conducted by the parties themselves separately, distant as their courts may be from one another, and incapable of meeting in consultation, suggest a question whether it will not be better for them to give full powers for that purpose to their Ambassadors or other ministers resident at some one court of Europe, who shall form a Committee or Council for carrying this convention into effect; wherein the vote of each member shall be computed in proportion to the quota of his sovereign, and the majority so computed shall prevail in all questions within the view of this convention. The court of Versailles is proposed, on account of it's neighborhood to the Mediterranean, and because all those powers are represented there, who are likely to become parties to this convention.

"8. To save to that council the embarrassment of personal solicitations for office, and to assure the parties that their contributions will be applied solely to the object for which they are destined, there shall be no establishment of officers for the said Council, such as Commis, Secretaries, or any other kind, with either salaries or perquisites, nor any other lucrative appointments but such whose functions are to be exercised on board the sd vessels.

"9. Should war arise between any two of the parties to this convention it shall not extend to this 
enterprise, nor interrupt it; but as to this they shall be reputed at peace.

" Io. When Algiers shall be reduced to peace, the other pyratical states, if they refuse to discontinue their pyracies shall become the objects of this convention, either successively or together as shall seem best.

"II. Where this convention would interfere with treaties actually existing between any of the parties and the sd states of Barbary, the treaty shall prevail, and such party shall be allowed to withdraw from the operations against that state."

Spain had just concluded a treaty with Algiers at the expense of 3. millions of dollars, and did not like to relinquish the benefit of that until the other party should fail in their observance of it. Portugal, Naples, the two Sicilies, Venice, Malta, Denmark and Sweden were favorably disposed to such an association; but their representatives at Paris expressed apprehensions that France would interfere, and, either openly or secretly support the Barbary powers; and they required that I should ascertain the dispositions of the Count de Vergennes on the subject. I had before taken occasion to inform him of what we were proposing, and therefore did not think it proper to insinuate any doubt of the fair conduct of his government; but stating our propositions, I mentioned the apprehensions entertained by us that England would interfere in behalf of those piratical governments. " She dares not do it," said he. I pressed it no further. The other agents were 
satisfied with this indication of his sentiments, and nothing was now wanting to bring it into direct and formal consideration, but the assent of our government, and their authority to make the formal proposition. I communicated to them the favorable prospect of protecting our commerce from the Barbary depredations, and for such a continuance of time as, by an exclusion of them from the sea, to change their habits \& characters from a predatory to an agrictultural people: towards which however it was expected they would contribute a frigate, and it's expenses to be in constant cruise. But they were in no condition to make any such engagement. Their recommendatory powers for obtaining contributions were so openly neglected by the several states that they declined an engagement which they were conscious they could not fulfill with punctuality; and so it fell through.

May i 7 . In I 786 . while at Paris I became acquainted with John Ledyard of Connecticut, a man of genius, of some science, and of fearless courage, \& enterprise. He had accompanied Capt Cook in his voyage to the Pacific, had distinguished himself on several occasions by an unrivalled intrepidity, and published an account of that voyage with details unfavorable to Cook's deportment towards the savages, and lessening our regrets at his fate. Ledyard had come to Paris in the hope of forming a company to engage in the fur trade of the Western coast of America. He was disappointed in this, and being out of business, and of a roaming, restless character, I suggested to him the enterprise of exploring the 
Western part of our continent, by passing thro St. Petersburg to Kamschatka, and procuring a passage thence in some of the Russian vessels to Nootka Sound, whence he might make his way across the continent to America; and I undertook to have the permission of the Empress of Russia solicited. He eagerly embraced the proposition, and M. de Sémoulin, the Russian Ambassador, and more particularly Baron Grimm the special correspondent of the Empress, solicited her permission for him to pass thro' her dominions to the Western coast of America. And here I must correct a material error which I have committed in another place to the prejudice of the Empress. In writing some Notes of the life of Capt Lewis, ${ }^{\mathbf{I}}$ prefixed to his expedition to the Pacific, I stated that the Empress gave the permission asked, $\&$ afterwards retracted it. This idea, after a lapse of 26 years, had so insinuated itself into my mind, that I committed it to paper without the least suspicion of error. Yet I find, on recurring to my letters of that date that the Empress refused permission at once, considering the enterprise as entirely chimerical. But Ledyard would not relinquish it, persuading himself that by proceeding to St. Petersburg he could satisfy the Empress of it's practicability and obtain her permission. He went accordingly, but she was absent on a visit to some distant part of her dominions, ${ }^{2}$ and he pursued his course to within 200. miles of Kamschatka, where he was overtaken by an arrest from the Empress, brought back to Poland, and there dismissed. I must there-

'In Lewis and Clarke's Travels.

2 The Crimea. $-T$. J. 
fore in justice, acquit the Empress of ever having for a moment countenanced, even by the indulgence of an innocent passage thro' her territories this interesting enterprise.

May i 8 . The pecuniary distresses of France produced this year a measure of which there had been no example for near two centuries, \& the consequences of which, good and evil, are not yet calculable. For it's remote causes we must go a little back.

Celebrated writers of France and England had already sketched good principles on the subject of government. Yet the American Revolution seems first to have awakened the thinking part of the French nation in general from the sleep of despotism in which they were sunk. The officers too who had been to America, were mostly young men, less shackled by habit and prejudice, and more ready to assent to the suggestions of common sense, and feeling of common rights. They came back with new ideas \& impressions. The press, notwithstanding it's shackles, began to disseminate them. Conversation assumed new freedoms. Politics became the theme of all societies, male and female, and a very extensive \& zealous party was formed which acquired the appellation of the Patriotic party, who, sensible of the abusive government under which they lived, sighed for occasions of reforming it. This party comprehended all the honesty of the kingdom sufficiently at it's leisure to think, the men of letters, the easy Bourgeois, the young nobility partly from reflection, partly from mode, for these sentiments became matter of mode, and as such 
united most of the young women to the party. Happily for the nation, it happened at the same moment that the dissipations of the Queen and court, the abuses of the pension-list, and dilapidations in the administration of every branch of the finances, had exhausted the treasures and credit of the nation, insomuch that it's most necessary functions were paralyzed. To reform these abuses would have overset the minister; to impose new taxes by the authority of the King was known to be impossible from the determined opposition of the parliament to their enregistry. No resource remained then but to appeal to the nation. He advised therefore the call of an assembly of the most distinguished characters of the nation, in the hope that by promises of various and valuable improvements in the organization and regimen of the government, they would be induced to authorize new taxes, to controul the opposition of the parliament, and to raise the annual revenue to the level of expenditures. An Assembly of Notables therefore, about i 50. in number named by the King, convened on the $22 \mathrm{~d}$. of Feb. The Minister (Calonne) stated to them that the annual excess of expenses beyond the revenue, when Louis XVI. came to the throne, was 37. millions of livres; that 440. millns. had been borrowed to reestablish the navy; that the American war had cost them i 440. millns. (256. mils. of Dollars) and that the interest of these sums, with other increased expenses had added 40 millns. more to the annual deficit. (But a subseqt. and more candid estimate made it 56 . millns.) He proffered them an 
universal redress of grievances, laid open those grievances fully, pointed out sound remedies, and covering his canvas with objects of this magnitude, the deficit dwindled to a little accessory, scarcely attracting attention. The persons chosen were the most able \& independent characters in the kingdom, and their support, if it could be obtained, would be enough for him. They improved the occasion for redressing their grievances, and agreed that the public wants should be relieved; but went into an examination of the causes of them. It was supposed that Calonne was conscious that his accounts could not bear examination; and it was said and believed that he asked of the King to send 4 . members to the Bastile, of whom the M. de la Fayette was one, to banish 20. others, \& 2. of his Ministers. The King found it shorter to banish him. His successor went on in full concert with the Assembly. The result was an augmentation of the revenue a promise of economies in it's expenditure, of an annual settlement of the public accounts before a council, which the Comptroller, having been heretofore obliged to settle only with the King in person, of course never settled at all; an acknowledgment that the King could not lay a new tax, a reformation of the criminal laws abolition of torture, suppression of Corvées, reformation of the gabelles, removal of the interior custom houses, free commerce of grain internal \& external, and the establishment of Provincial assemblies; which allogether constituted a great mass of improvement in the condition of the nation. The establishment of the Provincial assem- 
blies was in itself a fundamental improvement. They would be of the choice of the people, one third renewed every year, in those provinces where there are no States, that is to say over about three fourths of the kingdom. They would be partly an Executive themselves, \& partly an Executive council to the Intendant, to whom the Executive power, in his province had been heretofore entirely delegated. Chosen by the people, they would soften the execution of hard laws, \& having a right of representation to the King, they would censure bad laws, suggest good ones, expose abuses, and their representations, when united, would command respect. To the other advantages might be added the precedent itself of calling the Assemblée des Notables, which would perhaps grow into habit. The hope was that the improvements thus promised would be carried into effect, that they would be maintained during the present reign, \& that that would be long enough for them to take some root in the constitution, so that they might come to be considered as a part of that, and be protected by time, and the attachment of the nation.

The Count, de Vergennes had died a few days before the meeting of the Assembly, \& the Count de Montmorin had been named Minister of foreign affairs in his place. Villedeuil succeeded Calonnes as Comptroller general, \& Lomenie de Bryenne, Archbishop of Thoulouse, afterwards of Sens, \& ultimately Cardinal Lomenie, was named Minister principal, with whom the other ministers were to transact the business of their departments, hereto. 
fore done with the King in person, and the Duke de Nivernois, and M. de Malesherbes were called to the Council. On the nomination of the Minister principal the Marshals de Segur \& de Castries retired from the departments of War \& Marine, unwilling to act subordinately, or to share the blame of proceedings taken out of their direction. They were suceeded by the Count de Brienne, brother of the Prime minister, and the Marquis de la Luzerne, brother to him who had been Minister in the United States.

May 24. A dislocated wrist, unsuccessfully set, occasioned advice from my Surgeon to try the mincral waters of Aix in Provence as a corroborant. I left Paris for that place therefore on the $28 \mathrm{th}$. of Feb. and proceeded up the Seine, thro' Champagne $\&$ Burgundy, and down the Rhone thro' the Beaujolais by Lyons, Avignon, Nismes to Aix, where finding on trial no benefit from the waters, I conclucled to visit the rice country of Piedmont, to see if anything might be learned there to benefit the rivalship of our Carolina rice with that, and thence to make a tour of the seaport towns of France, along it's Southern and Western Coast, to inform myself if anything could be done to favor our commerce with them.' From Aix therefore I took my route by Marseilles, Toulon, Hieres, Nice, across the Col de Tende, by Coni, Turin, Vercelli, Novara, Milan, Pavia, Novi, Genoa. Thence returning along the coast by Savona, Noli, Albenga, Oneglia, Monaco, Nice, Antibes, Frejus, Aix, Marseilles, Avignon,

r In Washington's edition of Jefferson's Writings (ix.. $3^{\mathrm{r}} \mathrm{3}$ ) a journal of this tour is printed. 
Nismes, Montpellier. Frontignan, Cette, Agde, and along the canal of Languedoc, by Bezieres, Narbonne, Cascassonne, Castelnaudari, thro' the Souterrain of St. Feriol and back by Castelnaudari, to Toulouse, thence to Montauban \& down the Garonne by Langron to Bordeaux. Thence to Rochefort, la Rochelle, Nantes, L'Orient, then back by Rennes to Nantes, and up the Loire by Angers, Tours, Amboise, Blois to New Orleans, thence direct to Paris where I arrived on the Ioth. of June. Soon after my return from this journey to wit, about the latter part of July, I received my younger daughter Maria from Virginia by the way of London, the youngest having died some time before.

The treasonable perfidy of the Prince of Orange, Stadtholder \& Captain General of the United Nethcrlands, in the war which England waged against them for entering into a treaty of commerce with the U.S. is known to all. As their Executive officer, charged with the conduct of the war, he contrived to baffle all the measures of the States General, to dislocate all their military plans, \& played false into the hands of England and against his own country on every possible occasion, confident in her protection, and in that of the King of Prussia, brother to his Princess. The States General indignant at this patricidal conduct applied to France for aid, according to the stipulations of the treaty concluded with her in 85. It was assured to them readily, and in cordial terms, in a letter from the Ct. de Vergennes to the Marquis de Verac, Ambassador of France at the Hague, of which the following is an extract. 
"Extrait de la depeche de Monsr. le Comte de Vergennes à Monsr. le Marquis de Verac, Ambassadeur de France à la Haye, du rer Mars i 786.

"Le Roi concourrera, autant qu'il sera en son pouvoir, au succes de la chose, et vous inviterez de sa part les patriotes de lui communiquer leurs vues, leurs plans, et leurs envieux. Vous les assurerez que le roi prend un interêt veritable à leurs personnes comme à leur cause, et qu' ils peuvent compter sur sa protection. Ils doivent y compter d' autant plus, Monsieur, que nous ne dissinulons pas que si Monsr. le Stadhoulder reprend son ancienne influence, le systeme Anglois ne tardera pas de prevaloir, et que notre alliance deviendroit un être de raison. Les Patriotes sentiront facilement que cette position seroit incompatible avec la dignité, comme avec la consideration de sa majesté. Mais dans le cas, Monsieur, ou les chefs des Patriotes auroient à craindre une scission, ils auroient le temps suffisant pour ramener ceux de leurs amis que les Anglomanes ont egarés, et preparer les choses de maniere que la question de nouveau mise en deliberation soit decidé selon leurs desirs. Dans cette hypothese, le roi vouts autorise à agir de concert avec eux, de suivre la direction qu' ils jugeront devoir vous donner, et d' employer tous les moyens pour augmenter le nombre des partisans de la bonne cause. Il me reste, Monsieur, il me reste, Monsieur, de vous parler de la sureté personelle des patriotes. Vous les assurerez que dans tout etat de cause, le roi les prend sous sa protection immediate, et vous ferez connoitre partout ou vous le jugerez necessaire, que sa Majesté 
regarderoit comme une offense personnelle tout ce qu' on entreprenderoit contre leur liberte. Il est à presumer que ce langage, tenu avec energie, en imposera à l'audace des Anglomanes et que Monsr. le Prince de Nassau croira courir quelque risque en provoquant le ressentiment de sa Majesté.'

This letter was communicated by the Patriots to me when at Amsterdam in I788. and a copy sent by me to Mr. Jay in my letter to him of Mar. i6. I 788 .

The object of the Patriots was to establish a representative and republican government. The majority of the States general were with them, but the majority of the populace of the towns was with the Prince of Orange; and that populace was played off with great effect by the triumvirate of $* * *$ Harris ${ }^{1}$ the English Ambassador afterwards Ld. Malmesbury, the Prince of Orange a stupid man, and the Princess as much a man as either of her colleagues in audaciousness, in enterprise, $\&$ in the thirst of domination. By these the mobs of the Hague were excited against the members of the States general, their persons were insulted \& endangered in the streets, the sanctuary of their houses was violated, and the Prince whose function \& duty it was to repress and punish these violations of order, took no steps for that purpose. The States General, for their own protection were therefore obliged to place their militia under the command of a Committee. The Prince filled the courts of London and Berlin

$$
\text { I Sir James Harris. }
$$


with complaints at this usurpation of his prerogatives, and forgetting that he was but the first servant of a republic, marched his regular troops against the city of Utrecht, where the States were in session. They were repulsed by the militia. His interests now became marshalled with those of the public enemy \& against his own country. The States therefore, exercising their rights of sovereignty, deprived him of all his powers. The great Frederic had died in August 86. $\quad$ He had never intended to break with France in support of the Prince of Orange. During the illness of which he died, he had thro' the Duke of Brunswick, declared to the Marquis de la Fayette, who was then at Berlin, that he meant not to support the English interest in Holland: that he might assure the government of France his only wish was that some honorable place in the Constitution should be reserved for the Stadtholder and his children, and that he would take no part in the quarrel unless an entire abolition of the Stadtholderate should be attempted. But his place was now occupied by Frederic William, his great nephew, a man of little understanding, much caprice, \& very inconsiderate; and the Princess his sister, altho' her husband was in arms against the legitimate authorities of the country, attempting to go to Amsterdam for the purpose of exciting the mobs of that place and being refused permission to pass a military post on the way, he put the Duke of Brunswick at the head of 20,000 men, and made demonstrations of marching on Holland. The King of France hereupon

voL, 1,-8.

$$
\text { 'Ire to Jay Aug. 6. 87.-T. J. }
$$


declared, by his Chargé des Affaires in Holland that if the Prussian troops continued to menace Holland with an invasion, his Majesty, in quality of Ally, was determined to succor that province. In answer to this Eden gave official information to Count Montmorin, that England must consider as at an end, it's convention, with France relative to giving notice of it's naval armaments and that she was arming generally. ${ }^{2}$ War being now imminent, Eden questioned me on the effect of our treaty with France in the case of a war, \& what might be our dispositions. I told him frankly and without hesitation that our dispositions would be neutral, and that I thought it would be the interest of both these powers that we should be so; because it would relieve both from all anxiety as to feeding their $\mathrm{W}$. India islands. That England too, by suffering us to remain so, would avoid a heavy land-war on our continent, which might very much cripple her proceedings elsewhere; that our treaty indeed obliged us to receive into our ports the armed vessels of France, with their prizes, and to refuse admission to the prizes made on her by her enemies: that there was a clause also by which we guaranteed to France her American possessions, which might perhaps force us into the war, if these were attacked. "Then it will be war, said he, for they will assuredly be attacked." 3 Liston, at Madrid, about the same time, made the same inquiries of Carmichael. The gorernment of France then declared a determination to

I My Ire Sep. 22. 87.-T. J. $\quad{ }^{2}$ My lre to J. Jay Sep. 24.-T. J.

3 lre to Carm. Dec. i 5.-T. J. 
form a camp of observation at Givet, commencel arming her marine, and named the Bailli de Suffrein their Generalissimo on the ()ean. She secretly engaged also in negotiations with Russia, Austria, \& Spain to form a quadruple alliance. The Duke of Brunswick having advanced to the confines of Holland, sent some of his officers to Givet to reconnoitre the state of things there, and report them to him. He said afterwards that "if there had been only a few tents at that place, he should not have advanced further, for that the King would not merely for the interest of his sister, engage in a war with France." But finding that there was not a single company there, he boldly entered the country took their towns as fast as he presented himself before them, and advancerl on Utrecht. 'The States had appointed the Rhingrave of Salm their Commander-in-chief, a Prince without talents, without courage, and without principle. He might have held out in Utrecht for a considerable time, but he surrendered the place without firing a gun, literally ran away \& hid himsclf so that for months it was not known what had become of him. Amsterdam was then attacked and capitulaterl. In the meantine the negotiations for the quarlruple alliance were 1roceeding favorably. But the secrecy with which they were attempted to be: conducted, was penetrated by Fraser, Chargé des affaires of England at St. Petersburg, who instantly notified his court, and gave the alarm to Prussia. The King saw at once what would be his situation between the jaws of France, Austria, and Russia. In great dismay he besought the court of London 
not to abandon him, sent Alvensleben to Paris to explain and soothe, and England thro' the D. of Dorset and Eden, renewed her conferences for accommodation. The Archbishop, who shuddered at the idea of war, and preferred a peaceful surrender of right to an armed vindication of it, received them with open arms, entered into cordial conferences, and a declaration, and counter declaration were cooked up at Versailles and sent to London for approbation. They were approved there, reached Paris at I O'clock of the 27 th. and were signed that night at Versailles. It was said and believed at Paris that M. de Montmorin, literally " pleuroit comme un enfant," when obliged to sign this counter declaration; so distressed was he by the dishonor of sacrificing the Patriots after assurances so solemn of protection, and absolute encouragement to proceed.' The Prince of Orange was reinstated in all his powers, now become regal. A great emigration of the Patriots took place, all were deprived of office, many exiled, and their property confiscated. They were received in France, and subsisted for some time on her bounty. Thus fell Holland, by the treachery of her chief, from her honorable independence to become a province of England, and so also her Stadtholder from the high station of the first citizen of a free republic, to be the servile Viceroy of a foreign sovereign. And this was effected by a mere scene of bullying \& demonstration, not one of the parties, France England or Prussia having ever really meant to encounter actual war

I My 1re to Jay Nov. 3. lre to J. Adams, Nov. I3.-T. J. 
for the interest of the Prince of Orange. But it had all the effect of a real and decisive war.

Our first essay in America to establish a federative government had fallen, on trial, very short of it's object. During the war of Independance, while the pressure of an external enemy hooped us together, and their enterprises kept us necessarily on the alert, the spirit of the people, excited by danger, was a supplement to the Confederation, and urged them to zealous exertions, whether claimed by that instrument, or not. But when peace and safety were restored, and every man became engaged in useful and profitable occupation, less attention was paid to the calls of Congress. The fundamental defect of the Confederation was that Congress was not authorized to act immediately on the people, \& by it's own officers. Their power was only requisitory, and these requisitions were addressed to the several legislatures, to be by them carried into execution, without other coercion than the moral principle of duty. This allowed in fact a negative to every legislature, on every measure proposed by Congress; a negative so frequently exercised in practice as to henumb the action of the federal government, and to render it inefficient in it's general objects, \& more especially in pecuniary and foreign concerns. The want too of a separation of the legislative, executive, \& judiciary functions worked disadvantageously in practice. Yet this state of things afforded a happy augury of the future march of our confederacy, when it was seen that the good sense and good dispositions of the people, as soon as they perceived the 
incompetence of their first compact, instead of leaving it's correction to insurrection and civil war, agreed with one voice to elect deputies to a general convention, who should peaceably meet and agree on such a constitution as "would ensure peace, justice, liberty, the common defence \& general welfare."

This Convention met at Philadelphia on the 25 th. of May '87. It sate with closed doors, and kept all it's proceedings secret, until it's dissolution on the I 7 th. of September, when the results of their labors were published all together. I received a copy early in November, and read and contemplated it's provisions with great satisfaction. As not a member of the Convention however, nor probably a single eitizen of the Union, had approved it in all it's parts, so I too found articles which I thought objectionable. The absence of express declarations ensuring freedom of religion, freedom of the press, freedom of the person under the uninterrupted protection of the Habeas corpus, \& trial by jury in civil as well as in criminal cases excited my jealotsy; and the re-eligibility of the President for life, I quite disapproved. I expressed freely in letters to my friends, and most particularly to $\mathrm{Mr}$. Madison \& General Washington, my approbations and objections. How the good should be secured, and the ill brought to rights was the difficulty. To refer it back to a new Convention might endanger the loss of the whole. My first idea was that the 9 . states first acting should accept it unconditionally, and thus secure what in it was good, and that the 4 . last should accept on the previous condition that 
certain amendments should be agreed to, but a better course was devised of accepting the whole and trusting that the good sense \& honest intention of our citizens would make the alterations which should be deemed necessary. Accordingly all accepted, 6. without objection, and 7. with recommendations of specified amendments. Those respecting the press, religion, \& juries, with several others, of great value, were accordingly made; but the Habeas corpus was left to the discretion of Congress, and the amendment against the reeligibility of the President was not proposed by that body. My fears of that feature were founded on the importance of the office, on the fierce contentions it might excitc among ourselves, if continuable for life, and the dangers of interference either with money or arms, by foreign nations, to whom the choice of an American President might become interesting. Examples of this abounded in history; in the case of the Roman emperors for instance, of the Popes while of any significance, of the German enperors, the Kings of Poland, \& the Deys of Barbary. I had observed too in the feudal History, and in the recent instance particularly of the Stadtholder of Holland, how easily offices or tenures for life slide into inheritances. My wish therefore was that the President should be elected for 7 . years \& be ineligible afterwards. This term I thought sufficient to enable him, with the concurrence of the legislature, to carry thro' \& establish any system of improvement he should propose for the general good. But the practice adopted I think is better allowing his 
continuance for 8 . years with a liability to be dropped at half way of the term, making that a period of probation. That his continuance should be restrained to 7 . years was the opinion of the Convention at an early stage of it's session, when it voted that term by a majority of 8 . against 2 . and by a simple majority that he should be ineligible a second time. This opinion \&c. was confirmed by the house so late as July 26, referred to the committee of detail, rereported favorably by them, and changed to the present form by final vote on the last day but one only of their session. ${ }^{1}$ Of this change three states expressed their disapprobation, N. York by recommending an amendment that the President should not be eligible a third time, and Virginia and $N$. Carolina that he should not be capable of serving more than 8 . in any term of $I 6$. years. And altho' this amendment has not been made in form, yet practice seems to have established it. The example of 4 Presidents voluntarily retiring at the end of their 8 th year, \& the progress of public opinion that the principle is salutary, have given it in practice the force of precedent \& usage; insomuch that should a President consent to be a candidate for a 3 d. election, I trust he would be rejected on this demonstration of ambitious views.

But there was another amendment of which none of us thought at the time and in the omission of which lurks the germ that is to destroy this happy

I This is an evident error. On September 4 th, the committee of eleven reported a clause making the term four years, which was adopted by the convention on the $6 \mathrm{th}$, and not altcred thereafter. 
combination of National powers in the General goverument for matters of National concern, and independent powers in the states for what concerns the states severally. In England it was a great point gained at the Revolution, that the commissions of the judges, which had hitherto been during pleasure. should thenceforth be made during good behavior. A Judiciary dependent on the will of the King had proved itself the most oppressive of all tools in the hands of that Magistrate. Nothing then could be more salutary than a change there to the tenure of good behavior; and the question of good behavior left to the vote of a simple majority in the two houses of parliament. Before the revolution we were all good English Whigs, cordial in their free principles, and in their jealousies of their executive Magistrate. These jealousies are very apparent in all our state constitutions; and, in the general government in this instance, we have gone even beyond the English caution, by requiring a vote of two thirds in one of the Houses for removing a judge; a vote so impossible where ${ }^{\prime}$ any defence is made, before men of ordinary prejudices $\&$ passions, that our judges are cffectually independent of the nation. But this ought not to be. I would not indeed make them dependant on the Executive authority, as they formerly were in England; but I deem it indispensable to the continuance of this government that they should be submitted to some practical \&

${ }^{I}$ In the impeachment of judge Pickering of New Hampshire, a habitual \& maniac drunkard, no defence was made. Had there been. the party vote of more than one third of the Senate would have acquitted him.-T.J. 
impartial controul: and that this, to be imparted, must be compounded of a mixture of state and federal authorities. It is not enough that honest men are appointed judges. All know the influence of interest on the mind of man, and how unconsciously his judgment is warped by that influence. To this bias add that of the esprit de corps, of their peculiar maxim and creed that "it is the office of a good judge to enlarge his jurisdiction," and the absence of responsibility, and how can we expect impartial decision between the General government, of which they are themselves so eminent a part, and an individual state from which they have nothing to hope or fear. We have seen too that, contrary to all correct example, they are in the habit of going out of the question before them, to throw an anchor ahead and grapple further hold for future advances of power. They are then in fact the corps of sappers $\&$ miners, steadily working to undermine the independant rights of the States, \& to consolidate all power in the hands of that government in which they have so important a freehold estate. But it is not by the consolidation, or concentration of powers, but by their distribution, that good government is effected. Were not this great country already divided into states, that division must be made, that each might do for itself what concerns itself directly, and what it can so much better do than a distant authority. Every state again is divided into counties, each to take care of what lies within it's local bounds; each county again into townships or wards, to manage minuter details; and every ward into 
farms, to be governed each by it's individual proprietor. Were we directed from Washington when to sow, \& when to reap, we should soon want bread. It is by this partition of cares, descending in gradation from general to particular, that the mass of human affairs may be best managed for the good and prosperity of all. I repeat that I do not charge the judges with wilful and ill-intentioned error; but honest error must be arrested where it's toleration leads to public ruin. As, for the safety of society, we commit honest maniacs to Bedlam, so judges should be withdrawn from their bench, whose erroneous biases are leading us to dissolution. It may indeed injure them in fame or in fortune; but it saves the republic, which is the first and supreme law.

Among the debilities of the government of the Confederation, no one was more distinguished or more distressing than the utter impossibility of obtaining, from the states, the monies necessary for the payment of debts, or even for the ordinary expenses of the government. Some contributed a little, some less, \& some nothing, and the last furnished at length an excuse for the first to do nothing also. Mr. Adams, while residing at the Hague, had a general authority to borrow what sums might be requisite for ordinary \& necessary expenses. Interest on the public debt, and the maintenance of the diplomatic establishment in Europe, had been hatitually provided in this way. He was now elected Vice President of the U S. was soon to return to America, ${ }^{1}$ and had referred our bankers to me for

\footnotetext{
- Adams returned to America before his election as Vice President.
} 
future councel on our affairs in their hands. But I had no powers, no instructions, no means, and no familiarity with the subject. It had always been exclusively under his management, except as to occasional and partial deposits in the hands of $\mathrm{Mr}$. Grand, banker in Paris, for special and local purposes. These last had been exhausted for some time, and I had fervently pressed the Treasury board to replenish this particular deposit; as Mr. Grand now refused to make further advances. They answered candidly that no funds could be obtained until the new government should get into action, and have time to make it's arrangements. Mr. Adams had received his appointment to the court of London while engaged at Paris, with Dr. Franklin and myself, in the negotiations under our joint commissions. He had repaired thence to London, without returning to the Hague to take leave of that government. He thought it necessary however to do so now, before he should leave Europe, and accordingly went there. I learned his departure from London by a letter from Mrs. Adams received on the very day on which he would arrive at the Hague. A consultation with him, \& some provision for the future was indispensable, while we could yet avail ourselves of his powers. For when they would be gone, we should be without resource. I was daily dunned by a company who had formerly made a small loan to the $U$ $\mathrm{S}$. the principal of which was now become due; and our bankers in Amsterdam had notified me that the interest on our general debt would be expected in June; that if we failed to pay it, it would be deemed 
an act of bankruptcy and would effectually destroy the credit of the U S. and all future prospect of obtaining money there; that the loan they had been authorized to open, of which a third only was filled, had now ceased to get forward, and rendered desperate that hope of resource. I saw that there was not a moment to lose, and set out for the Hague on the $2 \mathrm{~d}$. morning after receiving the information of Mr. Adams's journey. I went the direct road by Louvres, Senlis, Roye, Pont St. Maxence, Bois le duc, Gournay, Peronne, Cambray, Bouchain, Valenciennes, Mons, Bruxelles, Malines, Antwerp, Mordick, and Rotterdam, to the Hague, where I happily found Mr. Adams. He concurred with me at once in opinion that something must be done, and that we ought to risk ourselves on doing it without instructions, to save the credit of the U S. We foresaw that before the new government could be adopted, assembled, establish it's financial system, get the money into the treasury, and place it in Europe, considerable time would elapse; that therefore we had better provide at once for the years 88. 89. \& 90 . in order to place our government at it's ease, and our credit in security, during that trying interval. We set out therefore by the way of Leyden for Amsterdam, where we arrived on the roth. I had prepared an estimate showing that

Florins.

there would be necessary for the year $88-531,937-10$

$89-538,540$

Total, $\frac{90-473,540}{1,544,017-10}$ 
Flor.

to meet this the bankers had in hand $79,268-2-8$

$\&$ the unsold bonds would yield $542,800 \quad 622,068-2-8$

leaving a deficit of

we proposed then to borrow a million yielding

which would leave a small deficiency of

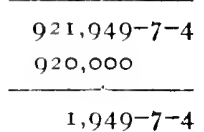

Mr. Adams accordingly executed ıoo. bonds, for 1000. florins each, and deposited them in the hands of our bankers, with instructions however not to issue them until Congress should ratify the measure. This done, he returned to London, and I set out for Paris; and as nothing urgent forbade it, I determined to return along the banks of the Rhine to Strasburg, and thence strike off to Paris. I accordingly left Amsterdam on the 3 oth of March, and proceeded by Utrecht, Nimeguen, Cleves, Duysberg, Dusseldorf, Cologne, Bonne, Coblentz, Nassau, Hocheim, Frankfort, \& made an excursion to Hanau, thence to Mayence and another excursion to Rudesheim, \& Johansberg; then by Oppenheim, Worms, and Manheim, and an excursion to Heidelberg, then by Spire, Carlsruh, Rastadt \& Kelh, to Strasburg, where I arrived Apr. I6th, and procceded again on the I8th, by Phalsbourg, Fenestrange, Dieuze, Moyenvie, Nancy, Toul, Ligny, Barleduc, St. Diziers, Vitry, Chalons sur Marne, Epernay, Chateau Thierri, Mcaux, to Paris where I arrived on the 23 d. of April ' ; and I had the satisfaction to reflect that by this journey our credit was secured, the new government was placed at ease for two years to come, and that

${ }^{I}$ A journal of this tour, kept by Jefferson, is printed in Washington's edition of his writings, ix., 373 . 
as well as myself were relieved from the torment of incessant duns, whose just complaints could not be silenced by any means within our power.

A Consular Convention had been agreed on in 84 . between Dr. Franklin and the French government containing several articles so entirely inconsistent with the laws of the several states, and the general spirit of our citizens, that Congress withheld their ratification, and sent it back to me with instructions to get those articles expunged or modified so as to render them compatible with our laws. The minister retired unwillingly from these concessions, which indeed authorized the exercise of powers very offensive in a free state. After much discussion it was reformed in a considerable degree, and the Convention was signed by the Count Montmorin and myself, on the I4th. of Nov. 88 not indeed such as I would have wished; but such as could be obtained with good humor \& friendship. ${ }^{\mathrm{r}}$

On my return from Holland, I had found Paris still in high fermentation as I had left it. Had the Archbishop, on the close of the assembly of Notables, immediately carried into operation the measures contemplated, it was believed they would all have been registered by the parliament, but he was slow, presented his edicts, one after another, \& at considerable intervals of time, which gave time for the feelings excited by the proceedings of the Notables to cool off, new claims to be advanced, and a pressure

I Among the Jefferson MSS. in the Department of State are printed copies of both the consular conventions negotiated by Franklin and Jefferson, and the original draft of the latter, in Jefferson's handwriting. 
to arise for a fixed constitution, not subject to changes at the will of the King. Nor should we wonder at this pressure when we consider the monstrous abuses of power under which this people were ground to powder, when we pass in review the weight of their taxes, and inequality of their distribution; the oppressions of the tythes, of the tailles, the corvées, the gabelles, the farms \& barriers; the shackles on Commerce by monopolies; on Industry by gilds \& corporations; on the freedom of conscience, of thought, and of speech; on the Press by the Censure; and of person by lettres de Cachet. the cruelty of the criminal code generally, the atrocities of the Rack, the venality of judges, and their partialities to the rich; the Monopoly of Military honors by the Noblesse; the enormous expenses of the Queen, the princes \& the Court; the prodigalities of pensions; \& the riches, luxury, indolence \& immorality of the clergy. Surely under such a mass of misrule and oppression, a people might justly press for a thoro' reformation, and might even dismount their rough-shod riders, \& leave them to walk on their own legs. The edicts relative to the corvées \& free circulation of grain, were first presented to the parliament and registered. But those for the impôt territorial, \& stamp tax, offered some time after, were refused by the parliament, which proposed a call of the States General as alone competent to their authorization. Their refusal produced a Bed of justice, and their exile to Troyes. The advocates however refusing to attend them, a suspension in the administration of justice took place. 
The Parliament held out for awhile, but the ennui of their exile and absence from Paris begun at length to be felt, and some dispositions for compromise to appear. On their consent therefore to prolong some of the former taxes, they were recalled from exile, the King met them in session Nov. 19. 87. promised to call the States General in the year 92. and a majority expressed their assent to register an edict for successive and annual loans from $I_{7} 88$. to 92. But a protest being entered by the Duke of Orleans and this encouraging others in a disposition to retract, the King ordered peremptorily the registry of the edict, and left the assembly abruptly. The parliament immediately protested that the rotes for the enregistry had not been legally taken, and that they gave no sanction to the loans proposed. This was enough to discredit and defeat them. Hereupon issued another edict for the establishment of a cour plenière, and the suspension of ail the parliaments in the kingdom. This being opposed as might be expected by reclamations from all the parliaments $\&$ provinces, the King gave way and by an edict of July 5. 88 renounced his cour plenière, \& promised the States General for the Ist. of May of the ensuing year: and the Archbishop finding the times beyond his faculties, accepted the promise of a Cardinal's hat, was removed [Sep. S8] from the ministry, and Mr. Necker was called to the department of finance. The innocent rejoicings of the people of Paris on this change provoked the interference of an officer of the city guards, whose order for their dispersion not being obeyed, he charged them with fixed bayonets, 
killed two or three, and wounded many. This dispersed them for the moment; but they collected the next day in great numbers, burnt 10. or 12. guard houses, killed two or three of the guards, \& lost 6 . or 8. more of their own number. The city was hereupon put under martial law, and after awhile the tumult subsided. The effect of this change of ministers, and the promise of the States General at an early day, tranquillized the nation. But two great questions now occurred. I. What proportion shall the number of deputies of the tiers etat bear to those of the Nobles and Clergy? And 2. shall they sit in the same, or in distinct apartments? Mr. Necker, desirous of avoiding himself these knotty questions, proposed a second call of the same Notables, and that their advice should be asked on the subject. They met Nov. 9. 88. and, by five bureaux against one, they recommended the forms of the States General of i6r4. wherein the houses were separate, and voted by orders, not by persons. But the whole nation declaring at once against this, and that the tiers etat should be, in numbers, equal to both the other orders, and the Parliament deciding for the same proportion, it was determined so to be, by a declaration of Dec. 27.88. A Report of Mr. Necker to the King, of about the same date, contained other very important concessions. I. That the King could neither lay a new tax, nor prolong an old one. 2. It expressed a readiness to agree on the periodical meeting of the States. 3. To consult on the necessary restriction on lettres de Cachet. And 4. how far the Press might be made free. 5. It admits that 
the States are to appropriate the public money; and 6. that Ministers shall be responsible for public expenditures. And these concessions came from the very heart of the King. He had not a wish but for the good of the nation, and for that object no personal sacrifice would ever have cost him a moment's regret. But his mind was weakness itself, his constitution timid, his judgment null, and without sufficient firmness even to stand by the faith of his word. His Queen too, haughty and bearing no contradietion, had an absolute ascendency over him; and around her were rallied the King's brother d'Artois, the court generally, and the aristocratic part of his ministers, particularly Breteuil, Broglio, Vauguyon, Foulon, Luzerne, men whose principles of government were those of the age of Louis XIV. Against this host the good counsels of Necker, Montmorin, St. Priest, altho' in unison with the wishes of the King himself, were of little avail. The resolutions of the morning formed under their advice, would be reversed in the evening by the influence of the Queen \& court. But the hand of heaven weighed heavily indeed on the machinations of this junto; producing collateral incidents, not arising out of the case, yet powerfully co-exciting the nation to force a regeneration of it's government, and overwhelming with aeeumulated diffieulties this liberticide resistance. For, while laboring under the want of money for even ordinary purposes, in a government which required a million of livres a day, and driven to the last diteh by the minirsal eall for liberty, there came on a winter of sncl! severe cold, as was without 
example in the memory of man, or in the written records of history. The Mercury was at times $50^{\circ}$ below the freezing point of Fahrenheit and $22^{\circ}$ below that of Reaumur. All out-door labor was suspended, and the poor, without the wages of labor, were of course without either bread or fuel. The government found it's necessities aggravated by that of procuring immense quantities of fire-wood, and of keeping great fires at all the cross-streets, around which the people gathered in crowds to avoid perishing with cold. Bread too was to be bought, and distributed daily gratis, until a relaxation of the season should enable the people to work: and the slender stock of bread-stuff had for some time threatened famine, and had raised that article to an enormous price. So great indeed was the scarcity of bread that from the highest to the lowest citizen, the bakers were permitted to deal but a scanty allowance per head, even to those who paid for it; and in cards of invitation to dine in the richest houses, the guest was notified to bring his own bread. To eke out the existence of the people, every person who had the means, was called on for a weekly subscription, which the Curés collected and employed in providing messes for the nourishment of the poor, and vied with each other in devising such economical compositions of food as would subsist the greatest number with the smallest means. This want of bread had been foreseen for some time past and M. de Montmorin had desired me to notify it in America, and that, in addition to the market price, a premium should be given on what should be brought from 
the U S. Notice was accordingly given and produced considerable supplies. Subsequent information made the importations from America, during the months of March, April \& May, into the Atlantic ports of France, amount to about 2 I,000 barrels of flour, besides what went to other ports, and in other months, while our supplies to their West-Indian islands relieved them also from that drain. This distress for bread continued till July.

Hitherto no acts of popular violence had been produced by the struggle for political reformation. Little riots, on ordinary incidents, had taken place, as at other times, in different parts of the kingdom, in which some lives, perhaps a dozen or twenty, had been lost, but in the month of April a more serious one occurred in Paris, unconnected indeed with the revolutionary principle, but making part of the history of the day. The Fauxbourg St. Antoine is a quarter of the city inhabited entirely by the class of day-laborers and journeymen in every line. A rumor was spread among them that a great paper manufacturer, of the name of Reveillon, had proposed, on some occasion, that their wages should be lowered to I 5 sous a day. Inflamed at once into rage, \& without inquiring into it's truth, they flew to his house in vast numbers, destroyed everything in it, and in his magazines \& work shops, without secreting however a pin's worth to themselves, and were continuing this work of devastation when the regular troops were called in. Admonitions being disregarded, they were of necessity fired on, and a regular action ensued, in which about roo. of them 
were killed, before the rest would disperse. There had rarely passed a year without such a riot in some part or other of the Kingdom; and this is distinguished only as cotemporary with the revolution, altho' not produced by it.

The States General were opened on the 5 th. of May 89. by speeches from the King, the Garde des Sceaux Lamoignon, and Mr. Necker. The last was thought to trip too lightly over the constitutional reformations which were expected. His notices of them in this speech were not as full as in his previous 'Rapport au Roi.' This was observed to his disadvantage. But much allowance should have been made for the situation in which he was placed between his own counsels, and those of the ministers and party of the court. Overruled in his own opinions, compelled to deliver, and to gloss over those of his opponents, and even to keep their secrets, he could not come forward in his own attitude.

'The composition of the assembly, altho' equivalent on the whole to what had been expected, was something different in it's elements. It had been supposed that a superior education would carry into the scale of the Commons a respectable portion of the Noblesse. It did so as to those of Paris, of it's vicinity and of the other considerable cities, whose greater intercourse with enlightened society had liberalized their minds, and prepared them to advance up to the measure of the times. But the Noblesse of the country, which constituted two thirds of that body, were far in their rear. Residing constantly on their patrimonial feuds, and familiar- 
ized by daily habit with Seigneurial powers and practices, they had not yet learned to suspect their inconsistence with reason and right. They were willing to submit to equality of taxation, but not to descend from their rank and prerogatives to be incorporated in session with the tiers etat. Among the clergy, on the other hand, it had been apprehended that the higher orders of the hierarchy, by their wealth and connections, would have carried the elections generally. But it proved that in most cases the lower clergy had obtained the popular majorities. These consisted of the Curés, sons of the peasantry who had been employed to do all the drudgery of parochial services for 10. 20. or 30 Louis a year; while their superiors were consuming their princely revenues in palaces of luxury \& indolence.

The objects for which this body was convened being of the first order of importance, I felt it very interesting to understand the views of the parties of which it was composed, and especially the ideas prevalent as to the organization contemplated for their government. I went therefore daily from Paris to Versailles, and attended their debates, generally till the hour of adjournment. Those of the Noblesse were impassioned and tempestuous. They had some able men on both sides, and actuated by equal zeal. The debates of the Commons were temperate, rational and inflexibly firm. As preliminary to all other business, the awful questions came on, Shall the States sit in one, or in distinct apartments? And shall they vote by heads or houses? The opposition was soon found to consist of the Episcopal 
order among the clergy, and two thirds of the Noblesse; while the tiers etat were, to a man, united and determined. After various propositions of compromise had failed, the Commons undertook to cut the Gordian knot. The Abbe Sieyes, the most logical head of the nation (author of the pamphlet Qu'est ce que le tiers etat? which had electrified that country, as Paine's Common sense did us) after an impressive speech on the Ioth of June, moved that a last invitation should be sent to the Nobles and Clergy, to attend in the Hall of the States, collectively or individually for the verification of powers, to which the commons would proceed immediately, either in their presence or absence. This verification being finished, a motion was made, on the I 5 th. that they should constitute themselves a National assembly; which was decided on the $I 7$ th. by a majority of four fifths. During the debates on this question, about twenty of the Curés had joined them, and a proposition was made in the chamber of the clergy that their whole body should join them. This was rejected at first by a small majority only; but, being afterwards somewhat modified, it was decided affirmatively, by a majority of eleven. While this was under debate and unknown to the court, to wit, on the Igth. a council was held in the afternoon at Marly, wherein it was proposed that the King should interpose by a declaration of his sentiments, in a seance royale. A form of declaration was proposed by Necker, which, while it censured in general the proceedings both of the Nobles and Commons, announced the King's views, such as substan- 
tially to coincide with the Commons. It was agreed to in council, the seance was fixed for the $22 \mathrm{~d}$. the meetings of the States were till then to be suspended, and everything, in the meantime, kept secret. The members the next morning (2oth.) repairing to their house as usual, found the doors shut and guarded, a proclamation posted up for a seance royale on the 22 d. and a suspension of their meetings in the meantime. Concluding that their dissolution was now to take place, they repaired to a building called the "Jeu de paume" (or Tennis court) and there bound themselves by oath to each other, never to separate of their own accord, till they had settled a constitution for the nation, on a solid basis, and if separated by force, that they would reassemble in some other place. The next day they met in the church of St. Louis, and were joined by a majority of the clergy. The heads of the Aristocracy saw that all was lost without some bold exertion. The King was still at Marly. Nobody was permitted to approach him but their friends. He was assailed by falsehoods in all shapes. He was made to believe that the Commons were about to absolve the army from their oath of fidelity to him, and to raise their pay. The court party were now all rage and desperate. They procured a committee to be held consisting of the King and his ministers, to which Monsieur \& the Count d'Artois snould be admitted. At this committee the latter attacked Mr. Necker personally, arraigned his declaration, and proposed one which some of his prompters had put into his hands. Mr. Necker was brow-beaten and intimidated, and the 
King shaken. He determined that the two plans should be deliberated on the next day and the seance royale put off a day longer. This encouraged a fiercer attack on Mr. Necker the next day. His draught of a declaration was entirely broken up, \& that of the Count d'Artois inserted into it. Himself and Montmorin offered their resignation, which was refused, the Count d'Artois saying to Mr. Necker "No sir, you must be kept as the hostage; we hold you responsible for all the ill which shall happen." This change of plan was immediately whispered without doors. The Noblesse were in triumph; the people in consternation. I was quite alarmed at this state of things. The soldiery had not yet indicated which side they should take, and that which they should support would be sure to prevail. I considered a successful reformation of government in France, as ensuring a general reformation thro Europe, and the resurrection, to a new life, of their people, now ground to dust by the abuses of the governing powers. I was much acquainted with the leading patriots of the assembly. Being from a country, which had successfully passed thro' a similar reformation, they were disposed to my acquaintance, and had some confidence in me. I urged most strenuously an immediate compromise; to secure what the government was now ready to yield, and trust to future occasions for what might still be wanting. It was well understood that the King would grant at this time I. Freedom of the person by Habeas corpus. 2. Freedom of conscience. 3 . Freedom of the press. 4. Trial by jury. 5. A repre- 
sentative legislature. 6. Annual meetings. 7. The origination of laws. 8. The exclusive right of taxation and appropriation. And 9. 'The responsibility of ministers; and with the exercise of these powers they would obtain in future whatever might be further necessary to improve and preserve their constitution. They thought otherwise however, and events have proved their lamentable error. For after 3o. years of war, foreign and domestic, the loss of millions of lives, the prostration of private happiness, and foreign subjugation of their own country for a time, they have obtained no more, nor even that securely. They were unconscious of (for who could foresee?) the melancholy sequel of their wellmeant perseverance; that their physical force would be usurped by a first tyrant to trample on the independance, and even the existence, of other nations: that this would afford fatal example for the atrocious conspiracy of Kings against their people; would generate their unholy and homicide alliance to make common cause among themselves, and to crush, by the power of the whole, the efforts of any part, to moderate their abuses and oppressions.

When the King passed, the next day, thro' the lane formed from the Chateau to the Hotel des etats, there was a dead silence. He was about an hour in the House delivering his speech \& declaration. On his coming out a feeble cry of "Vive le Roy" was raised by some children, but the people remained silent \& sullen. In the close of his speech he had ordered that the members should follow him, $\&$ resume their deliberations the next day. The 
Noblesse followed him, and so did the clergy, except about thirty, who, with the tiers, remained in the room, and entered into deliberation. They protested against what the King had done, adhered to all their former proceedings, and resolved the inviolability of their own persons. An officer came to order them out of the room in the King's name. "Tell those who sent you, said Mirabeau, that we shall not move hence but at our own will, or the point of the bayonet." In the afternoon the people, uneasy, began to assemble in great numbers in the courts, and vicinities of the palace. This produced alarm. The Queen sent for Mr. Necker. He was conducted anidst the shouts and acclamations of the multitude who filled all the apartments of the palace. He was a few minutes only with the queen, and what passed between them did not transpire. The King went out to ride. He passed thro' the crowd to his carriage and into it, without being in the least noticed. As Mr. Neckar followed him universal acclamations were raised of "vive Monsr. Neckar, vive le sauveur de la France opprimée." He was conducted back to his house with the same demonstrations of affection and anxiety. About 200. deputies of the Tiers, catching the enthusiasm of the inoment, went to his house, and extorted from him a promise that he would not resign. On the 25 th. 48. of the Nobles joined the tiers, \& among them the D. of Orleans. There were then with them i 64 members of the Clergy, altho' the minority of that body still sat apart \& called themselves the chamber of the clergy. On the 26th. the Archbp. of Paris joined 
the tiers, as did some others of the clergy and of the Noblesse.

These proceedings had thrown the people into violent ferment. It gained the souldiery, first of the French guards, extended to those of every other denomination, except the Swiss, and even to the body gutards of the King. They began to quit their barracks, to assemble in squads, to declare they would defend the life of the King, but would not be the murderers of their fellow-citizens. They called themselves the souldiers of the nation, and left now no doubt on which side they would be, in case of rupture. Similar accounts came in from the troops in other parts of the kingdom, giving good reason to believe they would side with their fathers and brothers rather than with their officers. The operation of this medicine at Versailles was as sudden as it was powerful. The alarm there was so compleat that in the afternoon of the 27 th. the King wrote with his own hand letters to the Presidents of the clergy and Nobles, engaging them immediately to join the Tiers. These two bodies were debating $\&$ hesitating when notes from the Ct. d' Artois decided their compliance. They went in a body and took their seats with the tiers, and thus rendered the union of the orders in one chamber compleat.

The Assembly now entered on the business of their mission, and first proceeded to arrange the order in which they would take up the heads of their constitution, as follows:

First, and as Preliminary to the whole a general Declaration of the Rights of Man. Then specifically 
the Principles of the Monarchy; rights of the Nation; rights of the King; rights of the citizens; organization \& rights of the National assembly; forms necessary for the enactment of laws; organization \& functions of the provincial \& municipal assemblies; duties and limits of the Judiciary power; functions $\&$ duties of the military power.

A declaration of the rights of man, as the preliminary of their work, was accordingly prepared and proposed by the Marquis de la Fayette.

But the quiet of their march was soon disturbed by information that troops, and particularly the foreign troops, were advancing on Paris from various quarters. The King had been probably advised to this on the pretext of preserving peace in Paris. But his advisers were believed to have other things in contemplation. The Marshal de Broglio was appointed to their command, a high flying aristocrat, cool and capable of everything. Some of the French guards were soon arrested, under other pretexts, but really on account of their dispositions in favor of the National cause. The people of Paris forced their prison, liberated them, and sent a deputation to the Assembly to solicit a pardon. The Assembly recommended peace and order to the people of Paris, the prisoners to the King, and asked from him the removal of the troops. His answer was negative and dry, saying they might remove themselves, if they pleased, to Noyons or Soissons. In the meantime these troops, to the number of twenty or thirty thousand, had arrived and were posted in, and between Paris and Versailles. The bridges and passes were 
guarded. At three o'clock in the afternoon of the I I th July the Count de la Luzerne was sent to notify Mr. Neckar of his dismission, and to enjoin him to retire instantly without saying a word of it to anybody. He went home, dined, and proposed to his wife a visit to a friend, but went in fact to his country house at St. Ouen, and at midnight set out for Brussels. This was not known till the next day, i 2 th when the whole ministry was changed, except Villedeuil, of the Domestic department, and Barenton, Garde des sceaux. The changes were as follows:

The Baron de Breteuil, president of the council of finance; de la Galaisiere, Comptroller general in the room of Mr. Neckar; the Marshal de Broglio, minister of War, \& Foulon under him in the room of PuySegur; the Duke de la Vauguyon, minister of foreign affairs instead of the Ct. de Montmorin; de La Porte, minister of Marine, in place of the Ct. de la Luzerne; St. Priest was also removed from the council. Luzerne and Puy-Segur had been strongly of the Aristocratic party in the Council, but they were not considered as equal to the work now to be done. The King was now compleatly in the hands of men, the principal among whom had been noted thro' their lives for the Turkish despotism of their characters, and who were associated around the King as proper instruments for what was to be executed. The news of this change began to be known at Paris about $\mathrm{I}$. or 2. o'clock. In the afternoon a body of about 100 German cavalry were advanced and drawn up in the Place Louis XV. and about 200. Swiss posted at a little distance in their rear. This drew people to the 
spot, who thus accidentally found themselves in front of the troops, merely at first as spectators; but as their numbers increased, their indignation rose. They retired a few steps, and posted themselves on and behind large piles of stones, large and small, collected in that Place for a bridge which was to be built adjacent to it. In this position, happening to be in my carriage on a visit, I passed thro' the lane they had formed, without interruption. But the moment after I had passed, the people attacked the cavalry with stones. They charged, but the advantageous position of the people, and the showers of stones obliged the horse to retire, and quit the field altogether, leaving one of their number on the ground, \& the Swiss in their rear not moving to their aid. This was the signal for universal insurrection, and this body of cavalry, to avoid being massacred, retired towards Versailles. The people now armed themselves with such weapons as they could find in armorer's shops and private houses, and with bludgeons, and were roaming all night thro' all parts of the city, without any deciled object. The next day (I 3 th.) the assembly pressed on the king to send away the troops, to permit the Bourgeosie of Paris to arm for the preservation of order in the city, and offer[ed] to send a deputation from their body to tranquillize them; but their propositions were refused. A committee of magistrates and electors of the city are appointed by those bodies to take upon them it's government. The people, now openly joined by the French guards, force the prison of St. Lazare, release all the prisoners, and take a great 
store of corn, which they carry to the Corn-market. Here they get some arms, and the French guards begin to form \& train them. The City-committee determined to raise 48.000 Bourgeoise, or rather to restrain their numbers to 48.000. On the I t th. they send one of their members (Mons. de Corny) to the Hotel des Invalides, to ask arms for their GardeBourgeoise. He was followed by, and he found there a great collection of people. The Governor of the Invalids carne out and represented the impossibility of his delivering arms without the orders of those from whom he received them. De Corny advised the people then to retire, and retired himself; but the people took possession of the arms. It was remarkable that not only the Invalids themselves made no opposition, but that a body of 5000. foreign troops, within 400. yards, never stirred. M. de Corny and five others were then sent to ask arms of M. de Launay, governor of the Bastile. They found a great collection of people already before the place, and they immediately planted a flag of truce, which was answered by a like flag hoisted on the Parapet. The deputation prevailed on the people to fall back a little, advanced themselves to make their demand of the Governor, and in that instant a discharge from the Bastile killed four persons, of those nearest to the deputies. The deputies retired. I happened to be at the house of M. de Corny when he returned to it, and received from him a narrative of these transactions. On the retirement of the deputies, the people rushed forward \& almost in an instant were in possession of a fortification defended by roo. vol. i. - Io. 
men of infinite strength, which in other times had stood several regular sieges, and had never been taken. How they forced their entrance has never been explained. They took all the arms, discharged the prisoners, and such of the garrison as were not killed in the first moment of fury, carried the Governor and Lt. Governor to the Place de 'Grève (the place of public execution) cut off their heads, and sent them thro' the city in triumph to the Palais royal. About the same instant a treacherous correspondence having been discovered in M. de Flesselles, prevot des marchands, they seized him in the Hotel de Ville where he was in the execution of his office, and cut off his head. These events carried imperfectly to Versailles were the subject of two successive deputations from the assembly to the king, to both of which he gave dry and hard answers for nobody had as yet been permitted to inform him truly and fully of what had passed at Paris. But at night the Duke de Liancourt forced his way into the king's bed chamber, and obliged him to hear a full and animated detail of the disasters of the day in Paris. He went to bed fearfully impressed. 'The decapitation of de Launai worked powerfully thro' the night on the whole aristocratic party, insomuch that, in the morning, those of the greatest influence on the Count d'Artois repreșented to him the absolute necessity that the king should give up everything to the Assembly. This according with the dispositions of the king, he went about I 1. o'clock, accompanied only hy his brothers, to the Assembly, \& there read to them a speech, in which he asked their interpow 
tion to re-establish order. Altho' couched in terms of some caution, yet the manner in which it was delivered made it evident that it was meant as a surrender at discretion. He returned to the Chateau afoot, accompanied by the assembly. They sent off a deputation to quiet Paris, at the head of which was the Marquis de la Fayette who had, the same morning, been named Commandant en chef of the Milice Bourgeoise, and Mons Bailly, former President of the States General, was called for as Prevot des marchands. The demolition of the Bastile was now ordered and begun. A body of the Swiss guards of the regiment of Ventimille, and the city horse guards joined the people. The alarm at Versailles increased. The foreign troops were ordered off instantly. Every minister resigned. The king confirmed Bailly as Prevot des Marchands, wrote to Mr. Neckar to recall him, sent his letter open to the assembly, to be forwarded by them, and invited them to go with him to Paris the next day, to satisfy the city of his dispositions; and that night, and the next morning the Count d'Artois and M. de Montesson a deputy connected with him, Madame de Polignac, Madame de Guiche, and the Count de Vaudreuil, favorites of the queen, the Abbe de Vermont, her confessor, the Prince of Condé and Duke of Bourbon fled. The king came to Paris, leaving the queen in consternation for his return. Omitting the less important figures of the procession, the king's carriage was in the center, on each side of it the assembly, in two ranks afoot, at their head the $M$. de la Fayette, as Commander-in-chief, on horseback, and Bourgeois 
guards before and behind. About 60.000 citizens of all forms and conditions, armed with the muskets of the Bastile and Invalids, as far as they would go, the rest with pistols, swords, pikes, pruning hooks, seythes, \&c. lined all the streets thro' which the procession passed, and with the crowds of people in the streets, doors \& windows, saluted them everywhere with cries of "vive la nation," but not a single "vive le roy" was heard. The King landed at the Hotel de Ville. There M. Bailly presented and put into his hat the popular cockade, and addressed him. The King being unprepared, and unable to answer, Bailly went to him, gathered from him some scraps of sentences, and made out an answer, which he delivered to the audience as from the king. On their return the popular uries were "vive le roy et la nation." He was conducted by a garde bourgeoise to his palace at Versailles, \& thus concluded an amende honorable as no sovereign ever marle, and no people ever received.

And here again was lost another precious occasion of sparing to France the crimes and cruelties thro' which she has since passed, and to Europe, \& finally America the evils which flowed on them also from this mortal source. The king was now become a passive machine in the hands of the National Assembly, and had he been left to himself, he would have willingly acquiesced in whatever they should devise as best for the nation. A wise constitution would have been formed, hereditary in his line, himself 1) laced at it's head, with powers so large as to enable him to do all the good of his station, and so limited 
as to restrain him from it's abuse. This he would have faithfully administered, and more than this I do not believe he ever wished. But he had a Quecn of absolute sway over his wcak mind, and timid virtue; and of a character the reverse of his in all points. This angel, as gaudily painted in the rhapsodies of the Rhetor Burke, with some smartness of fancy, but no sound sense was proud, disdainful of restraint, indignant at all obstacles to her will, eager in the pursuit of pleasure, and firm enough to hold to her desires, or perish in their wreck. Her inordinate gambling and dissipations, with those of the Count d'Artois and others of her clique, had been a sensible item in the exhattstion of the treasury, which callal into action the reforming hand of the nation; and her opposition to it her inflexible perverseness, and dauntless spirit, led herself to the Guillotine, $\&$ drew the king on with her, and plunged the world into crimes \& calamities which will forever stain the pages of modern history. I have ever believed that had there been no queen, there would have been no revolution. No force would have been provoles nor excrcised. The king would have gone hand in hand with the wisdom of his sounder counsellors, who, guided by the increased lights of the age, wished only, with the same pace, to advance the principles of their social institution. The deed which closed the mortal course of these sovereigns, I shall neither approve nor condemn. I am not prepared to say that the first magistrate of a nation cannot commit treason against his con1ntry, or is unamenable to it's punishment: nor yet that where there is no written 
law, no regulated tribunal, there is not a law in our hearts, and a power in our hands, given for righteous employment in maintaining right, and redressing wrong. Of those who judged the king, many thought him wilfully criminal, many that his existence would keep the nation in perpetual conflict with the horde of kings, who would war against a regeneration which might come home to themselves, and that it were better that one should die than all. I should not have voted with this portion of the legislature. I should have shut up the Queen in a Convent, putting harm out of her power, and placed the king in his station, investing him with limited powers, which I verily believe he would have honestly exercised, according to the measure of his understanding. In this way no void would have been created, courting the usurpation of a military adventurer, nor occasion given for those enormities which demoralized the nations of the world, and destroyed, and is yet to destroy millions and millions of it's inhabitants. There are three epochs in history signalized by the total cxtinction of national morality. The first was of the successors of Alexander, not omitting himself. The next the successors of the first Cæsar, the third our own age. This was begun by the partition of Poland followed by that of the treaty of Pilnitz next the conflagration of Copenhagen; then the enormities of Bonaparte partitioning the earth at his will, and devastating it with fire and sword; now the conspiracy of kings, the successors of Bonaparte, blasphemously calling themselves the Holy Alliance, and treading in the footsteps of their incarcerated 
leader, not yet indeed usurping the government of other nations avowedly and in detail, but controuling by their armies the forms in which they will permit them to be governed; and reserving in petto the order and extent of the usurpations further meditated. But I will return from a digression, anticipated too in time, into which I have been led by reflection on the criminal passions which refused to the world a favorable occasion of saving it from the afflictions it has since suffered.

M. Necker had reached Basle before he was overtaken by the letter of the king, inviting him back to resume the office he had recently left. He returned immediately, and all the other ministers having resigned, a new administration was named, to wit St. Priest \& Montmorin were restored; the Archbishop of Bordeaux was appointed Garde des sceaux; La Tour du Pin Minister of War; La Luzerne Minister of Marine. This last was believed to have been effected by the friendship of Montmorin; for altho' differing in politics, they continued firm in friendship, \& Luzerne, altho' not an able man was thought an honest one. And the Prince of Bauvau was taken into the Council.

Seven princes of the blood royal, six ex-ministers. and many of the high Noblesse having fled, and the present ministers, except Luzerne, being all of the popular party, all the functionaries of government moved for the present in perfect harmony.

In the evening of Aug. 4. and on the motion of . the Viscount de Noailles brother in law of La Fayette, the assembly abolished all titles of rank, all the 
abusive privileges of feudalism, the tythes and casuals of the clergy, all provincial privileges, and, in fine, the Feudal regimen generally. To the suppression of tythes the Abbe Sieves was vehemently opposed; but his learned and logical arguments were unheeded, and his estimation lessened by a contrast of his egoism (for he was beneficed on them) with the generous abandonment of rights by the other members of the assembly. Many days were employed in putting into the form of laws the numerous demolitions of ancient abuses; which done, they proceeded to the preliminary work of a Declaration of rights. There being much concord of sentiment on the elements of this instrument, it was liberally framed, and passed with a very general approbation. They then appointed a Committee for the reduction of a projet of a Constitution, at the head of which was the Archbishop of Bordeat1x. I received from him, as Chairman of the Commitee a letter of July 20 . requesting me to attend and assist at their delibcrations; but I excused myself on the obvious considerations that my mission was to the king as Chief Magistrate of the nation, that my duties were limited to the concerns of my own country, and forbade me to intermeddle with the internal transactions of that in which I had been reecived under a specific character only. Their plan of a constitution was discussed in scetions, and so reported from time to time, as agreed to by the Committee. The first respected the general frame of the government; and that this should be formed into three departments, Executive, Legislative and Judiciary was generally agreed. But 
when they proceeded to subordinate developments, many and various shades of opinion eame into conflict, and schism, strongly marked, broke the Patriots into fragments of very discordant principles. The first question Whether there should be a king, met with no open opposition, and it was readily agreed that the government of France should be monarchical \& hereditary. Shall the king have a negative on the laws? shall that negative be absolute, or suspensive only? Shall there be two chambers of legislation? or one only? If two, shall one of them be hereditary? or for life? or for a fixed term? and named by the king? or elected by the people? These questions found strong differences of opinion, and produced repulsive combinations among the Patriots. The Aristocracy was cemented by a common principle of preserving the ancient regime, or whatever should be nearest to it. Making this their Polar star, they moved in phalanx, gave preponderance on every question to the minorities of the Patriots, and always to those who advocated the least change. The features of the new constitution were thus assuming a fearful aspect, and great alarm was produced among the honest patriots by these dissensions in their ranks. In this uncasy state of things, I received one day a note from the Marquis de la Fayctte, informing me that he should bring a party of six or eight friends to ask a dinner of me the next day. I assured him of their welcome. When they arrived, they were La Fayette himself, Duport, Barnave, Alexander La Meth, Blacon, Mounier, Maubourg, and Dagout. These were leading patriots, 
of honest but differing opinions sensible of the necessity of effecting a coalition by mutual sacrifices, knowing each other, and not afraid therefore to unbosom themselves mutually. This last was a material principle in the selection. With this view the Marquis had invited the conference and had fixed the time \& place inadvertently as to the embarrassment under which it might place me. The cloth being removed and wine set on the table, after the American manner, the Marquis introduced the objects of the conference by summarily reminding them of the state of things in the Assembly, the course which the principles of the constitution were taking, and the inevitable result, unless checked by more concord among the Patriots themselves. He observed that altho' he also had his opinion, he was ready to sacrifice it to that of his brethren of the same cause: but that a common opinion must now be formed, or the Aristocracy would carry everything, and that whatever they should now agree on, he, at the head of the National force, would maintain. The discussions began at the hour of four, and were continued till ten o'clock in the evening; during which time I was a silent witness to a coolness and candor of argument unusual in the conflicts of political opinion; to a logical reasoning, and chaste eloquence, disfigured by no gaudy tinsel of rhetoric or declamation, and truly worthy of being placed in parallel with the finest dialogues of antiquity, as handed to us by Xenophon, by Plato and Cicero. The result was an agreement that the king should have a suspensive veto on the laws, that the legislature should be com- 
posed of a single body only, \& that to be chosen by the people. This Concordate decided the fate of the constitution. The Patriots all rallied to the principles thus settled, carried every question agreeably to them, and reduced the Aristocracy to insignificance and impotence. But duties of exculpation were now incumbent on me. I waited on Count Montmorin the next morning, and explained to him with truth and candor how it had happened that my house had been made the scene of conferences of such a character. He told me he already knew everything which had passed, that, so far from taking umbrage at the use made of my house on that occasion, he carnestly wished I would habitually assist at such conferences, being sure I should be useful in moderating the warmer spirits, and promoting a wholesome and practicable reformation only. I told him I knew too well the duties I owed to the king, to the nation, and to my own country to take any part in councils concerning their internal government, and that I should persevere with care in the character of a neutral and passive spectator, with wishes only and very sincere ones, that those measures might prevail which would be for the greatest good of the nation. I have no doubt indeed that this conference was previously known and approved by this honest minister, who was in confidence and communication with the patriots, and wished for a reasonable reform of the Constitution.

Here I discontinue my relation of the French revolution. The minuteness with which I have so far given it's details is disproportioned to the general 
scale of my narrative. But I have thought it justified by the interest which the whole world must take in this revolution. As yet we are but in the first chapter of it's history. The appeal to the rights of man, which had been made in the U S. was taken up by France, first of the European nations. From her the spirit has spread over those of the South. The tyrants of the North have allied indeed against it, but it is irresistible. Their opposition will only multiply it's millions of human victims; their own satellites will catch it, and the condition of man thro' the civilized world will be finally and greatly ameliorated. This is a wonderful instance of great events from small causes. So inscrutable is the arrangement of causes $\&$ consequences in this world that a two-penny duty on tea, unjustly imposed in a sequestered part of it, changes the condition of all it's inhabitants. I have been more minute in relating the early transactions of this regencration because I was in circumstances peculiarly favorable for a knowledge of the truth. Possessing the confidence and intimacy of the leading patriots, \& more than all of the Marquis Fayette, their head and Atlas, who had no secrets from me, I learnt with correctness the views \& proceedings of that party; while my intercourse with the diplomatic missionaries of Europe at Paris, all of them with the court, and eager in prying into it's councils and proceedings, gave me a knolege of these also. My information was always and immediately committed to writing, in letters to Mr. Jay, and often to my friends, and a recurrence to these letters now insures me against errors of memory. 
These opportunities of information ceased at this period, with my retirement from this interesting scene of action. I had been more than a year soliciting leave to go home with a view to place my daughters in the society \& care of their friends, and to return for a short time to my station at Paris. But the metamorphosis thro' which our government was then passing from it's Chrysalid to it's Organic form suspended it's action in a great degree; and it was not till the last of August that I received the permission I had asked.--And here I cannot leave this great and good country without expressing my sense of it's preeminence of character among the nations of the earth. A more benevolent people, I have never known, nor greater warmth \& derotedness in their select friendships. Their kindness and accommodation to strangers is unparalleled, and the hospitality of Paris is beyond anything I had conceived to he practicable in a large city. Their eminence too in science, the communicative dispositions of their scientific men, the politeness of the general manners, the ease and vivacity of their conversation, give a charm to their society to be found nowhere else. In a comparison of this with other countries we have the proof of primacy, which was given to Themistocles after the battle of Salamis. Every general voted to himself the first reward of valor, and the second to Themistocles. So ask the travelled inhabitant of any nation, In what country on earth would you rather live? - Certainly in my own, where are all my friends, my relations, and the earliest \& sweetest affections and recollections of my life. Which would be your second choice? France. 
On the 26 th. of Sep. I left Paris for Havre, where I was detained by contrary winds until the 8 th. of Oct. On that day, and the gth. I crossed over to Cowes, where I had engaged the Clermont, Capt. Colley, to touch for me. She did so, but here again we were detained by contrary winds until the $22 \mathrm{~d}$. when we embarked and landed at Norfolk on the $23 \mathrm{~d}$. of November. On my way home I passed some days at Eppington in Chesterfield, the residence of my friend and connection, Mr. Eppes, and, while there, I received a letter from the President, Genl. Washington, by express, covering an appointment to be Secretary of State. I received it with real regret. My wish had been to return to Paris, where I had left my household establishment, as if there myself, and to see the end of the Revolution, which, I then thought would be certainly and happily closed in less than a year. I then meant to return home, to withdraw from Political life, into which I had been impresed by the circumstances of the times, to sink into the bosom of my family and friends, and devote myself to studies more congenial to my mind. In my answer of Dec. I 5. I expressed these dispositions candidly to the President, and my preference of a return to Paris; but assured him that if it was believed I could be more useful in the administration of the government, I would sacrifice my own inclinations without hesitation, and repair to that destination; this I left to his decision. I arrived at Monticello on the $23 \mathrm{~d}$. of Dec. where I received a second letter from the President, expressing his continued wish that I should take my station there, but leaving me still at liberty to con- 
tinue in my former office, if I could not reconcile myself to that now proposed. This silenced my reluctance, and I accepted the new appointment.

In the interval of my stay at home my eldest daughter had been happily married to the eldest son ${ }^{\mathrm{I}}$ of the Tuckahoe branch of Randolphs, a young gentleman of genius, science and honorable mind, who afterwards filled a dignified station in the General Government, \& the most dignified in his own State. I left Monticello on the Ist of March I 790. for New York. At Philadelphia I called on the venerable and beloved Franklin. He was then on the bed of sickness from which he never rose. My recent return from a country in which he had left so many friends, and the perilous convulsions to which they had been exposed, revived all his anxieties to know what part they had taken, what had been their course, and what their fate. He went over all in succession, with a rapidity and animation almost too much for his strength. When all his inquiries were satisfied, and a pause took place, I told him I had learnt with much pleasure that, since his return to America, he had been occupied in preparing for the world the history of his own life. I cannot say much of that, said he; but I will give you a sample of what I shall leave: and he directed his little grandson (William Bache) who was standing by the bedside, to hand him a paper from the table to which he pointed. He did so; and the Doctr. putting it into my hands, desired me to take it and read it at my leisure. It was about a quire of folio paper, written in a large and rumning ¿Thomas Mann Randolph. 
hand very like his own. I looked into it slightly, then shut it and said I would accept his permission to read it and would carefully return it. He said, "no, keep it." Not certain of his meaning, I again looked into it, folded it for my pocket, and said again, I would certainly return it. "No," said he, "keep it." I put it into my pocket, and shortly after took leave of him. He died on the $\mathrm{I} 7 \mathrm{th}$, of the ensuing month of April; and as I understood that he had bequeathed all his papers to his grandson William Temple Franklin, I immediately wrote to Mr. Franklin to inform him I possessed this paper, which I should consider as his property, and would deliver to his order. He came on immediately to New York, called on me for it, and I delivered it to him. As he put it into his pocket, he said carelessly he had either the original, or another copy of it, I do not recollect which. This last expression struck my attention forcibly, and for the first time suggested to me the thought that Dr. Franklin had meant it as a confidential deposit in my hands, and that I had done wrong in parting from it. I have not yet seen the collection he published of Dr. Franklin's works, ${ }^{1}$ and therefore know not if this is among them. I have been told it is not. It contained a narrative of the negotiations between Dr. Franklin and the British Ministry, when he was endeavoring to prevent the contest of arms which followed. The negotiation was brought about by the intervention of Ld. Howe and his sister, who, I believe, was called Lady Howe, but I may misremember her title. Ld. Howe seems

I It was printed in that edition. 
to have been friendly to Amcrica, and exceedingly anxious to prevent a rupture. His intimacy with Dr. Franklin, and his position with the Ministry induced him to undertake a mediation between them; in which his sister seemed to have been associated. They carried from one to the other, backwards and forwards, the several propositions and answers which past, and seconded with their own intercessions the importance of mutual sacrifices to preserve the peace $\&$ connection of the two countries. I remember that Ld. North's answers were dry, unyielding, in the spirit of unconditional submission, and betrayed an absolute indifference to the occurrence of a rupture; and he said to the mediators distinctly, at last that "a rebellion was not to be deprecated on the part of Great Britain; that the confiscations it would produce would provide for many of their friends." This expression was reported by the mediators to Dr. Franklin, and indicated so cool and calculated a purpose in the Ministry, as to render compromise hopeless, and the negotiation was discontinued. If this is not among the papers published, we ask what has become of it? I delivered it with my own hands into those of Temple Franklin. It certainly established views so atrocious in the British government that it's suppression would to them be worth a great price. But could the grandson of Dr. Franklin be in such degree an accomplice in the parricide of the memory of his immortal grandfather? The suspension for more than 20 . years of the general publication

I Neither this expression, nor any of Lord North's, were given in Franklin's narrative. Cf. Bigelow's Writings of Franklin, v. 440.

vol. $1 .-1 \mathrm{x}$. 
bequeathed and confided to him, produced for awhile hard suspicions against him: and if at last all are not published, a part of these suspicions may remain with some.

I arrived at New York on the 2 Ist. of Mar. where Congress was in session.

. So far July $29.2 \mathbf{I}$. 
A Selection from the Catalogue of

\title{
G. P. PUTNAM'S SONS
}

\author{
4 \\ Complete Catalogue sent \\ on application
}



"I have known nearly all the marked men of my time, but I bave never known one equal to Hamilton. "-Talleyrand.

\section{Alexander Hamilton}

\section{AN ESSAY ON AMERICAN UNION By FREDERICK SCOTT OLIVER}

Popular Edition, 16mo, with Portrait. Cloth, net, 75 cents. Limp Leather, net, \$1.25. Library Edition, 8vo, with 6 Portraits and a Map, net, $\$ 2.50$

"Adequately supplies a real want in political history. . . . A living portrait of the man hirnself is vigorously drawn in the midst of the historical and political chapters."-Fredekick Harrison in London Tribune.

A searching study and masterly presentment of the struggles of that critical period in American history which-thanks largely to the influence of Hamilton's potent personality-ended in a firm and enduring union of States which long threatened to remain jealous and discordant.

It presents also a striking and authentic portrait of Hamilton the man; it brings us to a right understanding of him as one of the most illustrious statesmen of ancient or modern times; it gives a just conception of the magnitude and solidity of his achievement; it surrounds him with his friends and enemies; and it sets him off against a panoramic background that could have been painted only by one who combined the artist's sense for the significant feature with an encyclopedic knowledge of the political history of the last quarter of the eighteenth and the opening vears of the nineteenth century.

\section{G. P. PUTNAM's SONS}

London 


\title{
The Journal of the Debates in the Convention Which Framed The Constitution of the United States
}

\author{
May-September, 1787
}

\section{As Recorded by JAMES MADISON}

\author{
Edited with Introduction and Notes by \\ GAILLARD HUNT
2Volumes. 8vo. \$.t.50 net per set. Uniform with Lodge's Edition of "The Federalist."

These two volumes coniprise Madison's complete recorà of the proceedings of the Constituticnal Convention and give in the notes comparative comments based upon that journal and the less complete chronicles of the

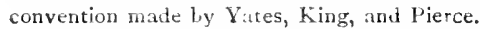

James Madison's contemporaries generally conceded that he was the seading statesman in the convention which framed the Constitution of the Uniced States; but in addition to this he kept a record of the proceedings of the convention which outranks in importance all the other writings of the founders of the American Republic. He is thus identified, as no other man is, with the making of the Constitution and the correct interpretation of the intentions of the makers. His is the only continuous record of the proseedings of the convention. He took a seat immediately in front of the presiding officer, facing the members, and took down every speech or motion as it was made, using abbreviations of his own and immediately afterwards transcribing his notes when he returned to his lodgings. A few motions only escaped him, and of important speeches he omitted none. The proceedings were ordere 1 to be kept secret, but his self-imposed cask of reporter had the official sanction of the convention.

\section{G. P. PUTNAM'S SONS}




\section{American Orations}

FROM THE COLONIAL PERIOD TO THE PRESENT TIME

Selected as specimens of eloquence, and with special reference to their value in throwing light upon the more important epochs and issues of American history.

Edited, with introductions and notes, by the late Alexander IOHNSTON, Professor of Jurisprudence in the College of New Jersey.

Re-edited, with new material and historical notes, by James A. WOODBURN, Professor of American History and Politics in Indiana Un:versity.

\section{FOUR VOLUMES,}

EACH COMPLETE IN ITSELF AND SOLD SEPARATELY

Crown octavo, gilt tops, per volume, $\$ 1.25$

Set, four volumes, in a box . $\quad 5.00$

Half calf, extra. * ,, 0.00

SERIES I. Colonialism-Constitutional Govern ment--The Rise of Democracy--The Rise of Nationality.

SERiEs Il. The Anti=Slavery Struggle.

SERIES lil. The Antim Slavery Struggle (Continued)-Secession.

EERIES IV. Civil War and Reconsfruction-.. Free Trade and Protection-..Finance and Civil=Service Reform.

"Regarded merely as studies in language, these orations contain some of the most eloquent and persuasive speeches in the English tongue. Brtt more than this, the present collection has a permanent historical value which can hardly be overestimated. The very spirit of the times is preserved in these utterances; and, presented in this cogent form, history in a peculiar sense repeats itself to the rcader, who fecls the imptilse of past ere:-is and the vitality of great principles behind them."--School 'fournal.

\section{G. P. PUTNAM'S SONS}

NEW YORK

LONDON 
"The best summary at present avallable of ths political history of the United States."

FD.ANK IH. HODDER, Professor of American History in the Jniversity of Kansas.

\title{
American Political History $1763=1876$
}

\section{By Alexander Johnston}

\author{
Edited and Supplemented by
}

\section{James Albert Woodburn}

Professor of History and J'olitical Srience, Ittiana Unt. versity; Author of "The American Republic,"

"Political Parties and Party Problems in the United States," etc.

In two parts, each complete in itself and indexed, Ocatue.

$$
\text { Each, net } \$ 2.00
$$

x. The Revolution, the Constitution, and the Growth of Nationality. I763-1832.

2. The Slavery Controversy, Secession, Civil War, and Reconstruction. 1820-1876.

These volumes present the principal features in the political history of the United States from the opening of the Amcrican Revolution to the close of the era of the Reconstruction. They give in more convenient form the series of articles on "American Political ilistory" contributed to Lalor's "Cyclopedia of Political Science, Political Economy, and Political History," hy the late Professor Alexander Johnston.

"These essays, covering the whole field of the political history of the United States, have a continuity and unity of purpose; introduced, urranged and supplentented as they have been by Professor Woodburn (who contributes a very necessary chapter on the Monroe Doctrine) they present a complete and well.balanced history of the politics of the United Statcs." - Hartford Courant.

\section{G. P. PUTNAM'S SONS}








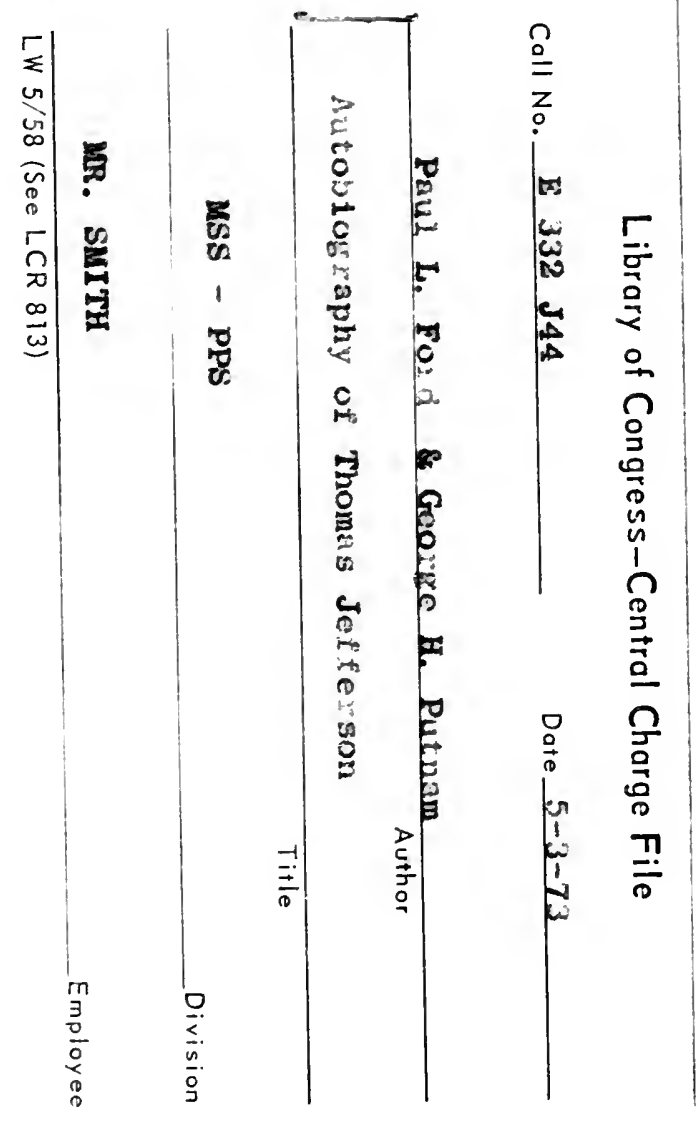




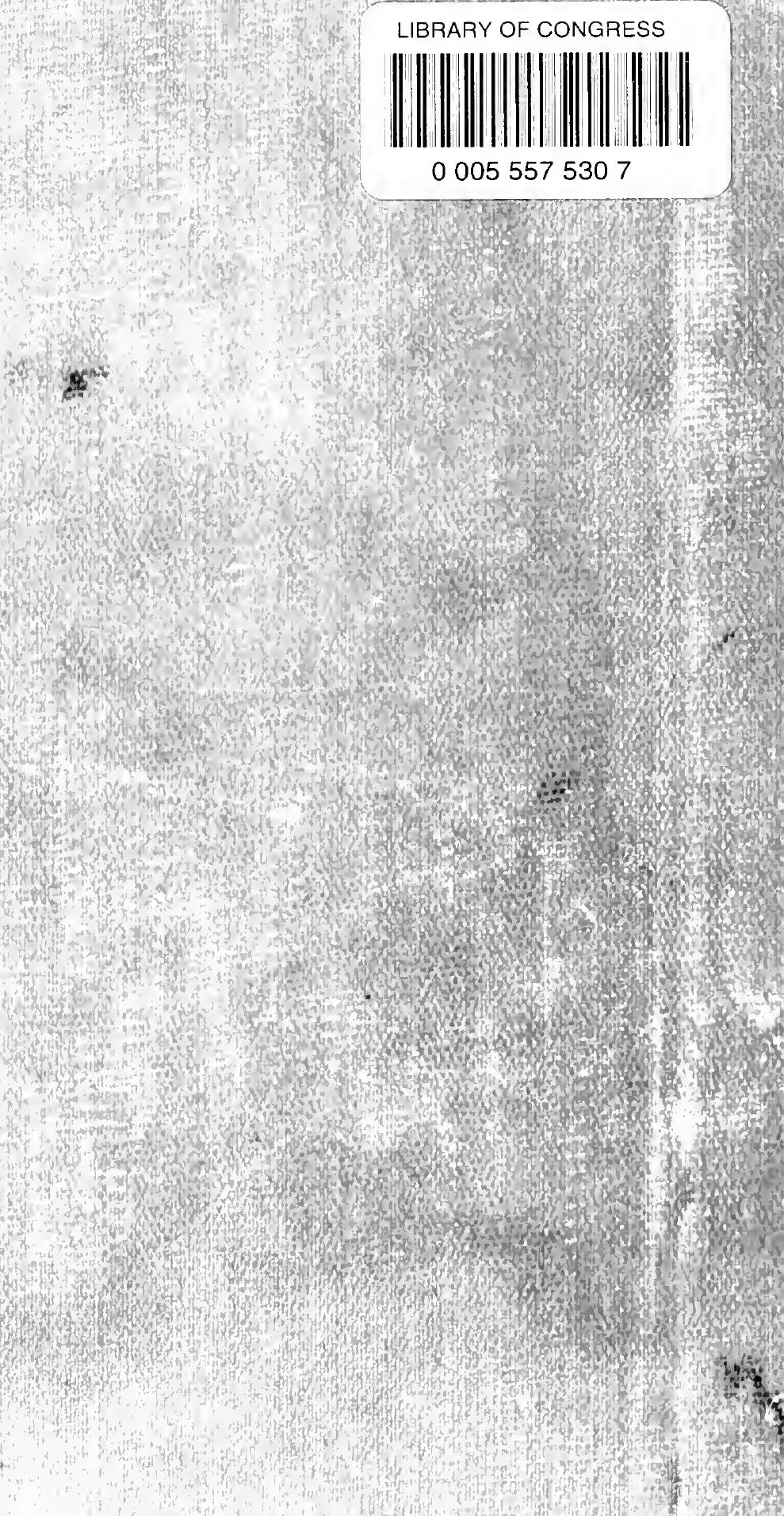

